New diagnostic and therapeutic possibilities in the treatment of elbow and distal forearm fractures in childhood

\author{
PhD THESIS
}

Marcell Benjámin Varga MD

\author{
University of Szeged
}

Doctoral School of Clinical Medicine

Szeged 2019 
New diagnostic and therapeutic possibilities in the treatment of elbow and distal forearm fractures in childhood

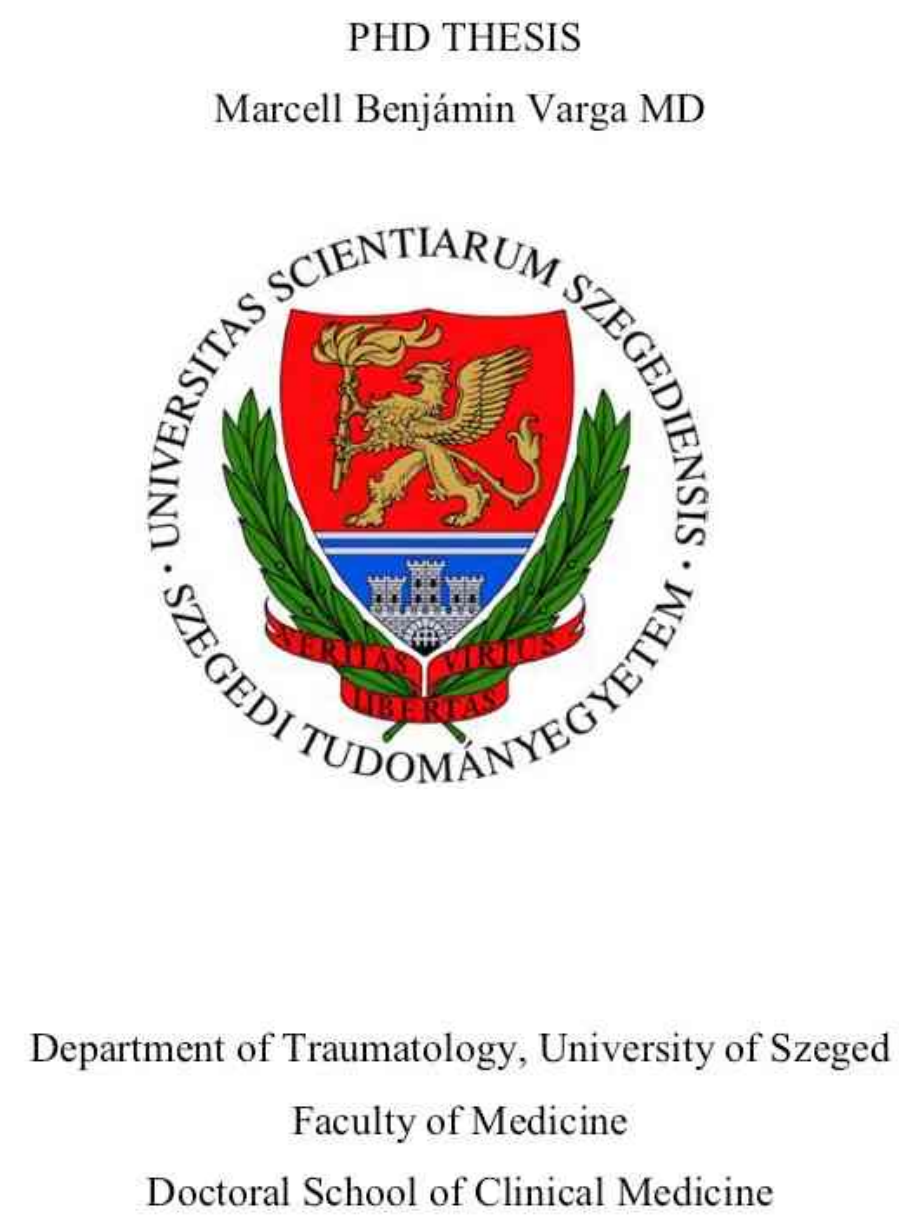

Supervisor: Dr. med.habil. Sándor Pintér Ph.D.

Szeged 2019 


\section{List of publications related to the subject of the thesis}

I. Intraoperative sonography may reduce the risk of extensor pollicis longus tendon injury

during dorsal entry elastic intramedullary nailing of the radius in children

Varga, M; Gáti, N; Kassai, T; Papp, S; Pintér, S

Medicine (Baltimore), 2018 vol. 97(24) pp. e11167

IF $: 2.028$

II. Ultrasonographic diagnosis of distal paediatric forearm fractures

Varga, M; Gáti, N; Kalóz, E; Bíró, Z; Szeverényi, C; Kardos, D; Józsa, G

Orv Hetil, 2017 vol. 158(24) pp. 944-948

IF:0.349

III. Short, double elastic nailing of severely displaced distal paediatric radial fractures: A new method for stable fixation

Varga, M; Józsa, G; Fadgyas, B; Kassai, T; Renner, A

Medicine (Baltimore), 2017 vol. 96(14) pp. e6532

IF $: 1.803$

IV. Gyermekkori csonttörések vizsgálata ultrahanggal

Magyar traumatológia, ortopédia, kézsebészet, plasztikai sebészet

Under publication, DOI: 10.21755/MTO.2018.061.0304.002

Varga, M; Tóth, L; Garancsy, G; Ribes, K; Pintér, S;

V. Nagy diszlokációval járó disztális gyermekkori radius metaphysis törések kezelése rövid elasztikus velöürszegezési technikával

Magyar traumatológia, ortopédia, kézsebészet, plasztikai sebészet

Under publication, DOI: DOI: 10.21755/MTO.2018.061.03.04.003

Varga, M; Kassai, T; Bíró, Zs; Kalóz, E; Józsa, G; Gáti, N; Pintér, S; 
List of abbreviations in the text

US ultrasound

PoCUS: $\quad$ point of care ultrasound

MSK-US: musculoskeletal ultrasound

IoP-MSK US intraoperative musculoskeletal ultrasound

PE pulled elbow

EPL extensor pollicis longus tendon

LH lipohemarthros

FPS fat pad sign

eFPS elevated fat pad sign

ED emergency department

$\mathrm{MHz} \quad$ megahertz

$\mathrm{SCH}$ fracture supracondylar humeral fracture

SFE synovial fringe enlargement 


\section{Contents}

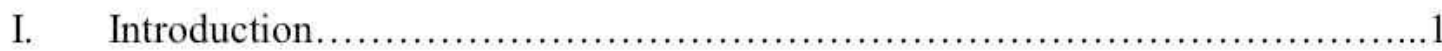

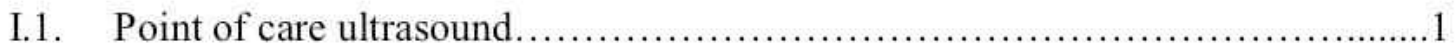

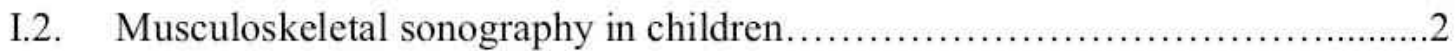

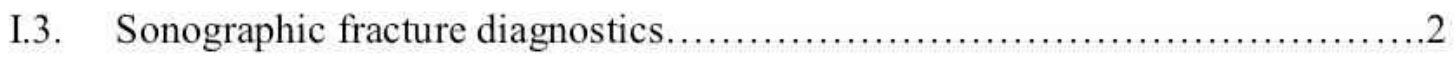

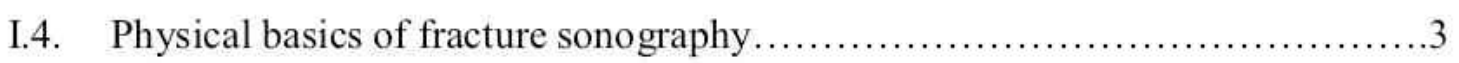

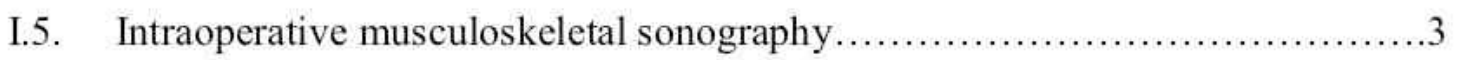

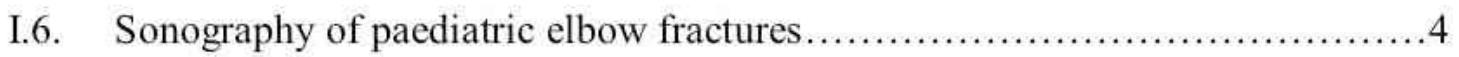

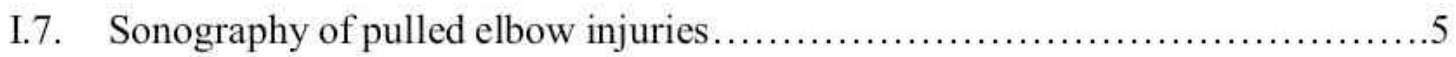

I.8. Sonographic diagnosis and treatment of paediatric distal forearm fractures.....6

I.9. Complications of radial elastic stable intramedullary nailing.................... 8

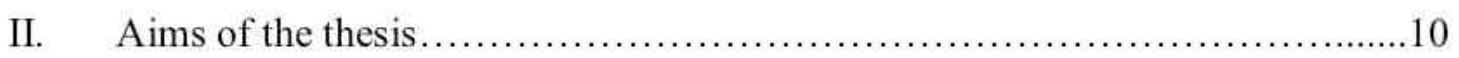

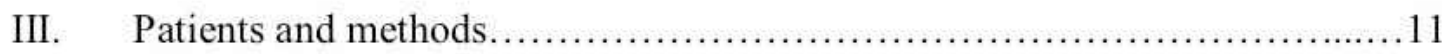

III.1. Sonographic diagnosis of elbow fractures.............................11

III.2. Sonographic diagnosis of pulled elbow................................ 14

III.3. Sonographic diagnosis of distal forearm fractures....................... 15

III.4. Short, elastic intra-medullary nailing of distal radial fractures.................17

III.4/1. Operative technique of short double elastic nailing .........................18

III.4/2. Operative technique of short mono-elastic nailing with End Cap.............20

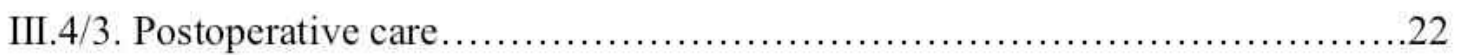

III.5. Intra-operative sonography of radial elastic stable intramedullary nailing.....22

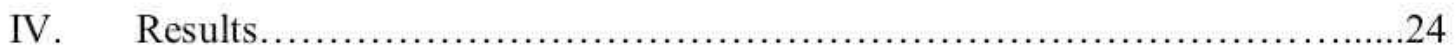

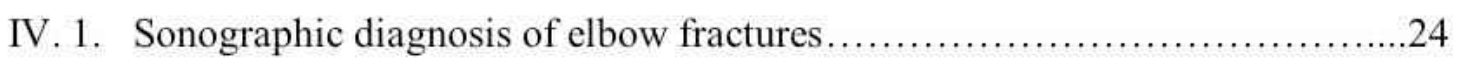

IV.2. Sonographic diagnosis of pulled elbow ........................................

IV.3. Sonographic diagnosis of distal forearm fractures .........................29 
IV.4. Short elastic intra-medullary nailing of distal forearm fractures.

IV.5. Intraoperative sonography of elastic stable intramedullary nailing.

V. Discussion

V.1. Sonographic diagnosis of elbow fractures........................................

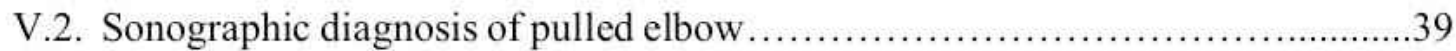

V. 3. Sonographic diagnosis of distal forearm fractures.............................40

V.4. Short elastic intra-medullary nailing of distal radial fractures.................43

V.5. Intra-operative sonography of elastic stable intramedullary nailing ..................45

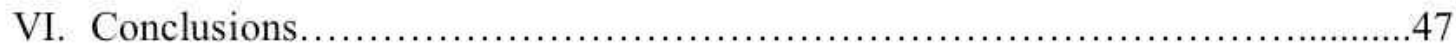

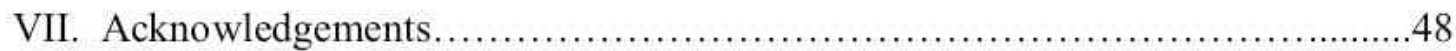

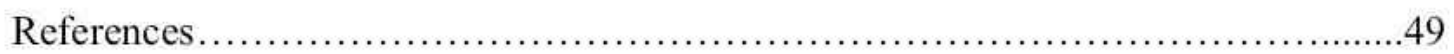




\section{Introduction}

Fractures of the elbow and distal forearm are among the most frequent injuries in children. $(1,2,3)$ The spectrum of these injuries is very wide from small contusions without clinical consequences to severely displaced fractures with limb threatening conditions. (4) Primary diagnosis and treatment are often performed by emergency physicians, general practitioners or paediatric surgeons. (5) Indications of unnecessary imaging procedures, under- and over-treatment may occur by less-specialised healthcare personnel. (5) Recognising certain elbow fractures may be a challenge even for an experienced orthopaedic surgeon due to the special characteristics of childhood. (6) Certain distal forearm and elbow fractures may not be detected by conventional $\mathrm{X}$-rays. $(7,8,9)$ The evaluation of severely displaced distal radius fractures and setting up a plan for further treatment may be particularly difficult due to the lack of therapeutic consensus. (10) In recent years, there have been a growing evidence that musculoskeletal ultrasound (MSK-US) can increase the effectiveness of diagnostics and may reduce the number of unnecessary X-rays. (11) Elastic intramedullary nailing of displaced distal radius fractures may have many advantages over traditional percutaneous pinning techniques. (12) Intra-operative musculoskeletal sonography (IoP MSK- US) can further increase the safety of these interventions. (13)

\section{I.1. Point of care ultrasound}

In recent decades, emergency ultrasound (US) diagnostics have undergone enormous development. (14) Point of care ultrasound (PoCUS) is the application of US to make immediate patient-care decisions. (15) These procedures are performed by nonradiologists who seek answers to targeted clinical questions. (15) The advantages of various PoCUS examinations are now proven by high-level evidence. (16) Musculoskeletal (MSK) PoCUS is a relatively new concept which has been enabled by the development of high-resolution sonography. (17) 


\section{I.2. Musculoskeletal sonography in children}

The guiding principle of radiation safety is the concept of "ALARA" (as law as reasonably achievable). The practice of this principle is especially important in childhood as the growing body is more sensitive to radiation. (18) Examinations with ionisation exposure should be performed only in cases when there is no alternative diagnostic test and the results may have clinical consequences. Although standard twoplane X-rays of a joint do not involve significant ionisation, there are no definite "safe minimal doses". (19) The practice of emergency departments (ED) show great differences in X-ray application even in the case of simple injuries. (20) MSK -US can be a diagnostic imaging alternative to X-rays in various paediatric injuries. (21) To our present knowledge, MSK-US does not have any harmful effects on the tissues and can be repeated unlimitedly. (21) Additional advantages of US are the portability, relative low cost, lack of radiation and no known contraindications. (22)

Application of MSK-US is examiner dependent and it may be difficult to carry out standardised examinations. (23) Nonetheless, examining individual areas can be learned quickly and effectively by healthcare staff who do not have any special radiological training. (24)

MSK-US involves the use of high-frequency sound waves up to 24 Megahertz (MHz) to image soft tissues and bony structures in the body for diagnosing pathology or guiding real-time interventional procedures. By increasing the frequency, better resolution is achieved, so penetration decreases to a few centimetres. (25) Given that most musculoskeletal structures are superficial, they can be clearly visualised by US. This is particularly advantageous in the areas of the wrist and the elbow, where the bones are covered with a thin soft tissue (26)

\section{I.3. Sonographic diagnostics of bone fractures}

The principle of fracture sonography has been reported by Leitglieb in 1986 . $(27,28)$ The first Hungarian reports were presented by Farbaky and al. in 2004. (29) Over the last two decades many papers confirmed the role of US in the diagnostics of various bone fractures. US had been demonstrated as an effective method for the detection of fractures of the skull, fingers, forearm, elbow, hip and sternum. $(30,31,32,33,34)$ It has 
also been used as a method for identifying stress injuries and occult fractures of the scaphoid bone, clavicle, rib, foot and ankle. $(34,35,36,37,38,39,40)$ Sonography of long bone fractures also can be used as fast screening method in emergency departments to facilitate triage. (41) Further researches have confirmed the diagnostic benefits of US for fracture detection in battlefields and in health care facilities with limited sources. (42) In a systematic review and meta-analysis Schmid and al. found $91 \%$ sensitivity and $94 \%$ specificity of US fracture identification following acute trauma. (43) Other systematic reviews showed similar results. $(11,22)$ The most accurate diagnostic matches between X-rays and sonography were shown at paediatric distal forearm, proximal humeral, elbow, ankle and long bone fractures. $(11,22,43)$ In 2015 the European Federation for Societies of Ultrasound in Medicine and Biology (EFSUMB) issued a recommendation on the sonographic fracture investigation and its documentation of paediatric wrist, elbow and proximal humeral fractures. (44) Although there is a considerable evidence that the sensitivity and specificity of US are high, randomised trials for high level evidences are still missing. (45) Despite the generally excellent results, US fracture diagnostics has not become a widespread routine and most local diagnostic protocol do not include its use. There can be several reasons for this. Most of the studies were made by emergency departments and investigated relatively small number of cases. It is a further problem that US is examiner dependent and requires special training. A physician's basic ultrasonic training is evident in an ED, but they are less experienced in paediatric orthopaedic trauma. (46) On the contrary, orthopaedic surgeons who provide definitive care usually do not have ultrasound qualifications. $(24,46)$

\section{I.4. Physical basics of fracture sonography}

The cortex of the bone completely reflects ultrasound waves. The cortical line can be mapped by a linear transducer if it is held parallel or perpendicular to the longitudinal axis of a tubular bone. (29) With modern devices even, a tenth of a millimetre cortical gap can be detected. $(25,29)$ Paediatric bone fractures (torus fractures, angulated greenstick fractures, epiphyseolysis) show a typical pattern. The degree of angulation can be measured with the same accuracy as shown in X-rays. A significant part of the paediatric joints is just partly ossified and consist mainly of cartilaginous tissue which 
is "invisible" to standard X-rays. (8) Chondral avulsions, apophyseal injuries which have a minimal ossification centre can also be visualised by sonography. (8) Fluid accumulation in the joints can be an indirect sign of occult fractures and it is easier to detect by US. $(23,25,29)$

\section{I.5. Intraoperative musculoskeletal sonography}

Intra- and postoperative application of high-resolution US in musculoskeletal trauma is a relatively new method for various purposes. MSK-US is advantageous in the visualisation of the relationship of various soft tissues (i.e. tendons, nerves, arteries) and implants which are undetectable by X-rays. It can also reduce the need of radiation. (29) Recently, several authors have reported positive experiences with US in different musculoskeletal operations. Lee and al. use US for intraoperative reduction of radial neck fractures. (47) Soldado and al. use sonography during medial pinning of paediatric supracondylar humeral fractures to avoid iatrogenic injury of the ulnar nerve. (48) Several papers confirmed the utility of peri- and postoperative use of sonography to detect dorsal cortical screw penetration after plate osteosynthesis of distal radial fractures. $(49,50)$ In a cadaveric study Saengsin and al. found that the reduction of femoral shaft fractures can be monitored by US during minimal invasive plate osteosynthesis. (51) Zhe and al. described ultrasound-guided intramedullary nailing of femoral shaft fractures which reduces intraoperative radiation exposure. (52) Initial results of US guided carpal-tunnel releases are encouraging. (53)

Ventral and dorsal area of the wrist is easily accessible for producing a detailed sonographic image due to the proximity of the soft tissues to the skin. Considering that operative approaches of paediatric forearm and wrist fractures are usually performed in a minimally invasive percutaneous way, IOP- US may be useful in this area to avoid iatrogenic soft tissue injuries. (13)

\section{I.6. Sonography of paediatric elbow fractures}

Elbow trauma is a very common injury in childhood. Elbow fractures account for 5 to $10 \%$ of all fractures in children. Accurate diagnosis of elbow injuries can be difficult in many aspects. A clinical suspect of paediatric elbow fracture is usually confirmed or 
excluded by standard two plane X-rays. (54) In children a large part of the elbow joint consists of cartilage. (54) Fractures which affect the cartilaginous part cannot be visualised directly by X-rays. $(8,55)$ It is also a difficulty that the elbow in growing children has six ossification centres which appear sequentially from 2 years of age. Distinguishing fractures from normal anatomic findings needs a special experience in paediatric trauma imaging. (54) Improper adjustments of the elbow during X-rays may result further mistakes. Indications of X-rays and interpretation of the results may differ depending on the providing physician. $(6,7)$ Occult fractures and other acute disorders can be misdiagnosed. (56) Radial condylar (RC)fractures are sometimes invisible on the first X-rays although they can have serious clinical consequences in the case of instability. (57) Recent years several studies confirmed the positive role of US in the diagnosis of paediatric elbow trauma. $(57,58,59,60,61,62,63)$ Most of these papers examined the significance of the sonographic fat pad sign (FPS) in certain types of fractures. Some papers suggest using standard sonographic planes. $(64,65)$ Despite the good and encouraging results no comprehensive, generally accepted method has been developed for daily clinical practice.

\section{I.7. Sonography of pulled elbow injuries}

The clinical entity known as ,, pulled” or "nursemaid elbow” (PE) or „radial head subluxation" is one of the most common upper limb injuries in childhood under the age of 5 years. $(66,67,68) \mathrm{PE}$ is caused typically by a sudden axial traction although certain injuries are associated with other mechanisms (69) Most protocols do not recommend any diagnostic imaging for confirming the presence of $\mathrm{PE}$, reduction manoeuvre can be carried out by the physical findings and typical anamnesis. (69) Usually the child holds his upper extremity in a pronated and extended position, refuses moving it and may complain of wrist and elbow pain. (69). In certain cases, the condition even can be diagnosed and treated remotely. (70) PE is a benign, age-specific injury, without further

clinical consequences when correctly recognised and adequately treated. $(65,66,67,68,69)$ The main problem of PE is the difficulty of differential diagnosis in a small percentage of cases. $(71,72)$ Clinical history is not always clear, and according to certain studies, $1-5 \%$ of children can have elbow fractures or other pathology which can mimic the physical findings of PE. $(73,74,75)$ This percentage can be even greater 
by first health providers who are not so experienced in paediatric musculoskeletal trauma. Mostly supracondylar humeral $(\mathrm{SCH})$ fractures can cause similar physical findings. (75) Reduction attempts in these cases can cause further unnecessary pain and iatrogenic dislocation. Application of reduction manoeuvres in uncertain cases without musculoskeletal imaging depend on the health provider's clinical decision. The most accepted method for ruling out fractures is a standard two plane radiograph. There is no clear recommendation that in which cases X-rays should be indicated. Considering that X-rays do not show clear pathognomonic sign for PE, most authors suggest that radiographs should be taken only in the cases of suspected fractures. (75) Few papers suggest the use of US to confirm PE. These studies are controversial, and authors report different sonographic characteristics of PE. $(76,77,78,79,80)$ To our knowledge, an objective and simple imaging method which can be used by a clinician has not been yet reported.

\section{I.8. Sonographic diagnosis and treatment of paediatric distal forearm fractures}

Distal forearm fractures are the most common skeletal injuries in children. $(2,3,4)$ Based on publications from different places in the world, their number has been growing steadily over the last thirty years. (81) Although generally these fractures show excellent healing tendency and good functional results, there are very different trends both in diagnostics and treatment worldwide. $(5,10)$ In recent years, many authors have confirmed that US is an effective tool in the diagnostics of these fractures. Paediatric distal forearm is one of the most intensively investigated area of US fracture diagnostics although most papers involved relatively small number of patients and were made by emergency physicians. $(82,83,84,85,86,87,88,89)$ Authors agree that US is as effective as X-rays for screening out negative cases and diagnosing fractures without displacement. At the same time there is some controversy if angulated or severely displaced fractures can be detected only by US. Publications generally deal only with primary diagnostics. A few authors reported other applications like US guided reduction. $(87,88,89)$

Torus or buckle fractures are very stable metaphyseal injuries without the risk of displacement. $(10,90)$ US shows similar effectivity as X-rays in the diagnosis of torus 
fractures. Torus fractures heal rapidly, there are enough evidence that a removable splint for three weeks is better than a rigid cast. There is no need for repeated X-rays because these injuries do not have any risk of late complications. $(10,90)$ Minimally displaced fractures can be treated similarly as torus fractures. (10) Angulated fractures up to 15 degrees with preserved continuity of the periosteum and under the age of 10 at girls, and 12 at boys can be treated with a simple splint and without any intervention. There is no agreement on how often these injuries should be controlled. (91) Most patients are checked by X-rays one or two times more until evidence of bone healing, although US could be a viable alternative in the judgement of angular deformity.

Displaced fractures beyond the acceptable limit of angulation need intervention. Most of them can be treated by closed reduction and 4-6 weeks rigid casting. $(10,92,93,94)$ The EFSUMB does not suggest US diagnostics in the case of a suspected displaced radius fracture because of the uncertain diagnostic accuracy. (44) There are no clear recommendations or high-level evidences for the treatment of severely displaced paediatric distal forearm fractures. $(93,94)$ Distal and severely displaced paediatric metaphyseal radial fractures with total rupture of the periosteum are generally considered unstable. Some authors suggest surgery only after unsuccessful conservative treatment, while others indicate operative interventions in the cases of potentially unstable fractures. (95) Contrary to adulthood, there is no need for an anatomic reduction in a child's distal forearm fracture. (96) Many studies confirmed the remodelling capacity of distal radial fractures in children. Very young children can tolerate even up to 40-50 degrees of distal radial angulation without late consequences. At the same time, the precise limitations of remodelling capacity are unclear. Most authors agree that a residual angulation of 15-30 degrees under the age of 10 at girls, and 12 at boys would totally remodel with time. $(10,95)$ Clinical judgement of greater deformities and older age groups is contradictory. Severely displaced and shortened distal fractures are usually candidates for operative interventions. These fractures are very deformed and unstable because of total periosteal rupture. Although theoretically even these fractures can heal and remodel by conservative treatment most authors choose operative intervention because total remodelling is uncertain and functional recovery takes a long time. (97)

The principles of surgery of paediatric distal forearm fractures have not changed in the past five decades. The gold-standard operative method is closed reduction and 
percutaneous pinning. Although the many variations of percutaneous pinning are simple and effective in unstable distal radial fractures, they can also have many potential complications and disadvantages. Kirschner wire related complications are well known; migration of the pins, superficial infections, damage of the growth plate, skin irritation, and insufficient biomechanical ability to maintain the reduction without casting. $(97,98,99,100,101,102)$ This latter fact is the main drawback of this technique: in addition to the discomfort associated with operation, it is usually necessary to wear a long or short rigid cast at least for 4 to 6 weeks postoperatively.Fractures in the area of the diametaphyseal junction represent a special problem: they are usually located too distally to be treated by conventional ESIN-technique and too proximal for Kirschner wire fixation. Lieber et al used transepiphyseal pinning in these cases. (103) Although the chance of an iatrogenic physeal injury is very small, a physeal arrest and progressive deformity can be a potential complication of any trans-epiphyseal stabilisation. $(104,105,106,107)$ Other authors suggest a specially prepended long, physeal sparing elastic nail to eliminate this problem. All these methods require postoperative rigid long arm cast immobilisation for 4 to 6 weeks. $(108,109,110,111)$

\section{I.9. Complications of radial elastic stable intramedullary nailing}

In the past three decades flexible intramedullary nailing of displaced and unstable forearm diaphyseal fractures has become the gold standard operative method in children. $(112.113,114)$ ESIN technique of the radius can be carried out from two entry points. (115) These are the lateral (distal radial side proximally from physis) and the dorsal approaches (through Lister's tubercle). $(112,113)$ (Figure 1,2) Both approaches have potential complications. Lateral entry point can cause a $2.9 \%$ rate of transient and $0.3 \%$ rate of permanent injury to the superficial branch of the radial nerve. Rarely a painful neuroma also can occur. (115) Dorsal approach can cause a $2.6 \%$ rate of extensor pollicis longus tendon (EPL) rupture. Due to the consequences of these complications, recent studies and the original description advocate using the lateral approach although considering biomechanical aspects, the dorsal technique is more advantageous in distal fractures. (115) 

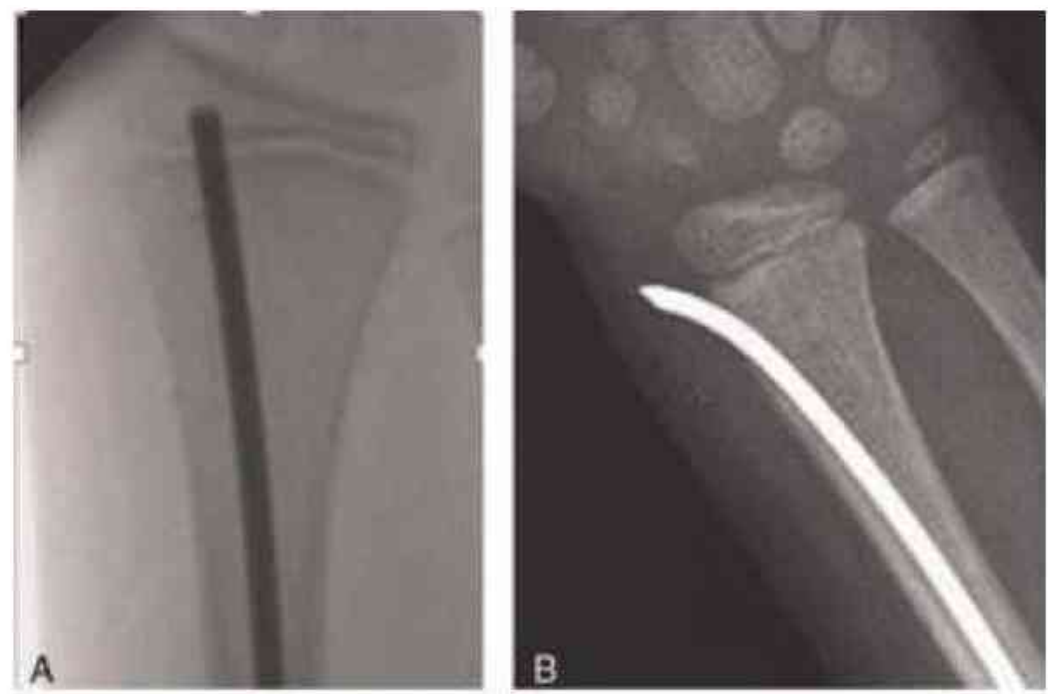

Figure 1. Anteroposterior X-rays of different radial approaches of ESIN techniques A: dorsal entry nailing B: lateral entry nailing
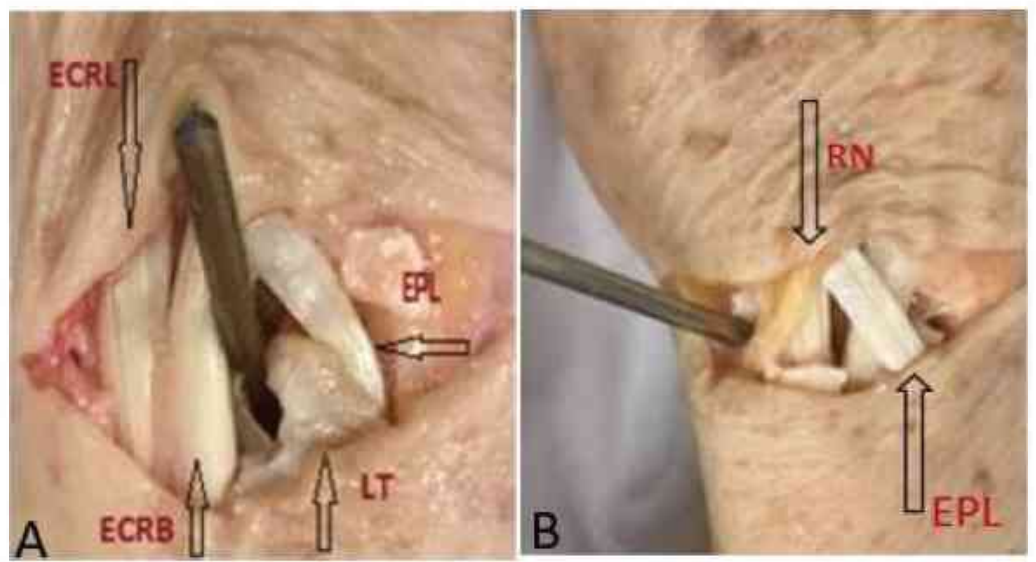

Figure 2. Relations of the elastic nail and the surrounding structures at the dorsal and at the lateral approaches (adult cadaver) A: Dorsal approaches (ERCL: extensor carpi radialis longus tendon, ECRB: extensor carpi radialis brevis tendon, EPL: extensor pollicis longus tendon, LT: lister's tubercle, B: Lateral approaches EPL: extensor pollicis longus RN: radial nerve 


\section{Aims of the thesis}

The aim was to prove the efficacy of a standardised five-point sonographic screening method of paediatric elbow fractures. US examinations were executed by orthopaedic surgeons in an emergency trauma centre.

In a prospective diagnostic study, we investigated a standardised two-points method in the differential diagnosis of paediatric pulled elbow. We developed an objective, point of care imaging method for confirming or ruling out PE.

We aimed to prove the diagnostic effectivity of ultrasound in distal paediatric forearm fractures in a prospective, two-centred study with large number of patients. Examinations were executed by orthopaedic and paediatric surgeons.

We also aimed to investigate the diagnostic difference of US in radial fractures with different clinical consequences.

We have developed a new operative method for severely displaced distal paediatric radial fractures. In our retrospective study we analysed the results of our technique, which is a stable, physis sparing osteosynthesis with a reduced period of necessary cast immobilisation.

We introduced a new ultrasound-assisted intraoperative aiming method for the ESIN technique of paediatric radius fractures. The aim of the procedure was to reduce the risk of EPL tendon injury during dorsal entry elastic nailing. This was an observational diagnostic study. 


\section{Patients and methods}

\section{III.1. Sonographic diagnosis of elbow fractures}

Between January 2016 and August 2017365 children (age 1-14) were enrolled in our study. Patients with isolated and closed elbow injury who needed standard two-plane elbow X-rays were included. We excluded children with open fractures and uncertain clinical symptoms when simultaneous indication of X-rays from other joints of the upper extremity were also needed. Point of care US was carried out as a part of the primary physical survey. US examinations were executed by a properly trained orthopaedic trauma resident and two orthopaedic surgeons. US pictures were made by high-frequency linear probes. (Zonare ZS3 Ultrasound System, Mindray ${ }^{\circledR}$, L20-5W and L-14-5W linear array transducers)

We used a standardised protocol, which included five longitudinal sonographic planes: a dorsal one above the olecranon fossa (plane I.), lateral and medial views of the distal humeral consoles (plane II and III) a lateral view of the proximal radius (plane IV) and an image of the proximal ulnar surface. (plane V). (Figure 3.)

Pictures were saved for further analyses. The other unaffected elbow was also scanned so we had a comparable reference point at each plane. In plane I. above the olecranon fossa we sought the presence or absence of the elevated dorsal sonographic fat pad sign (eFPS) or lipohemarthros (LH) whereas the other longitudinal planes served to confirm any angulation or disruption of the bony cortex. (Figure 4.,5.)

Immediately afterwards we made two-plane X-rays from the affected side according to protocol. At children whose primary X-rays were negative and/or any of the US planes showed positive findings, radiography was repeated after 4 weeks of injury. The fracture was considered occult, if we detected callus formation. Images which have not met with standard requirements were excluded.US pictures and X-rays were analysed and compared by the clinicians and a radiologist. The radiologist was clinically blinded to any patient related information. Interrater agreements by Cohen's chance corrected kappa statistics of sonographic fat pad sign and cortical plane abnormalities were calculated between the examiners and the radiologist. We used GraphPad QuickCals ${ }^{\circledR}$ program to calculate the degree of agreement with Kappa. 
We also estimated the rate of match of the presumed and final diagnosis. Presence of pathologic sonographic fat pad sign and the cortical abnormalities were evaluated separately and together. We used MEDCALC $®$ diagnostic test evaluation calculator to determine the specificity, sensitivity, positive and negative predictive values. Clinical approval of our diagnostic study was permitted by our Institutional Medical Board. An informed consent was obtained from the parents of all patients.
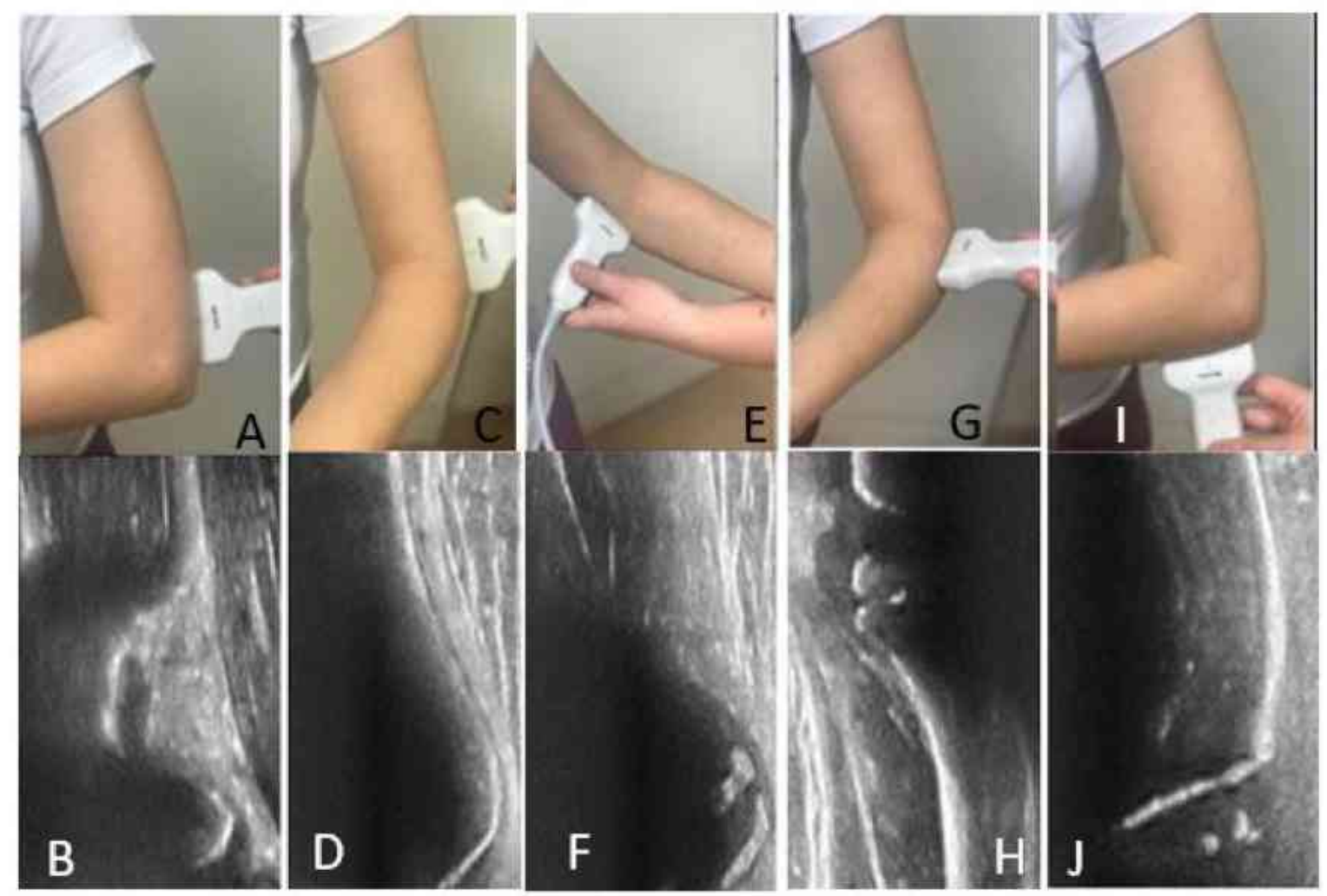

Figure 3.

Standard transducer positions and views of the five-point sonographic examination of elbow fracture in children.

A: plane I. transducer position. B: sonographic view of the olecranon fossa in plane I.

C: plane II. transducer position. D: sonographic view of the lateral humeral condyle in plane II. E: plane III. transducer position. F: sonographic view of the medial humeral condyle in plane III. G: plane IV. transducer position H: sonographic view of the proximal radius in plane IV. I: plane V. transducer position. J: sonographic view of the olecranon in plane $\mathrm{V}$. 


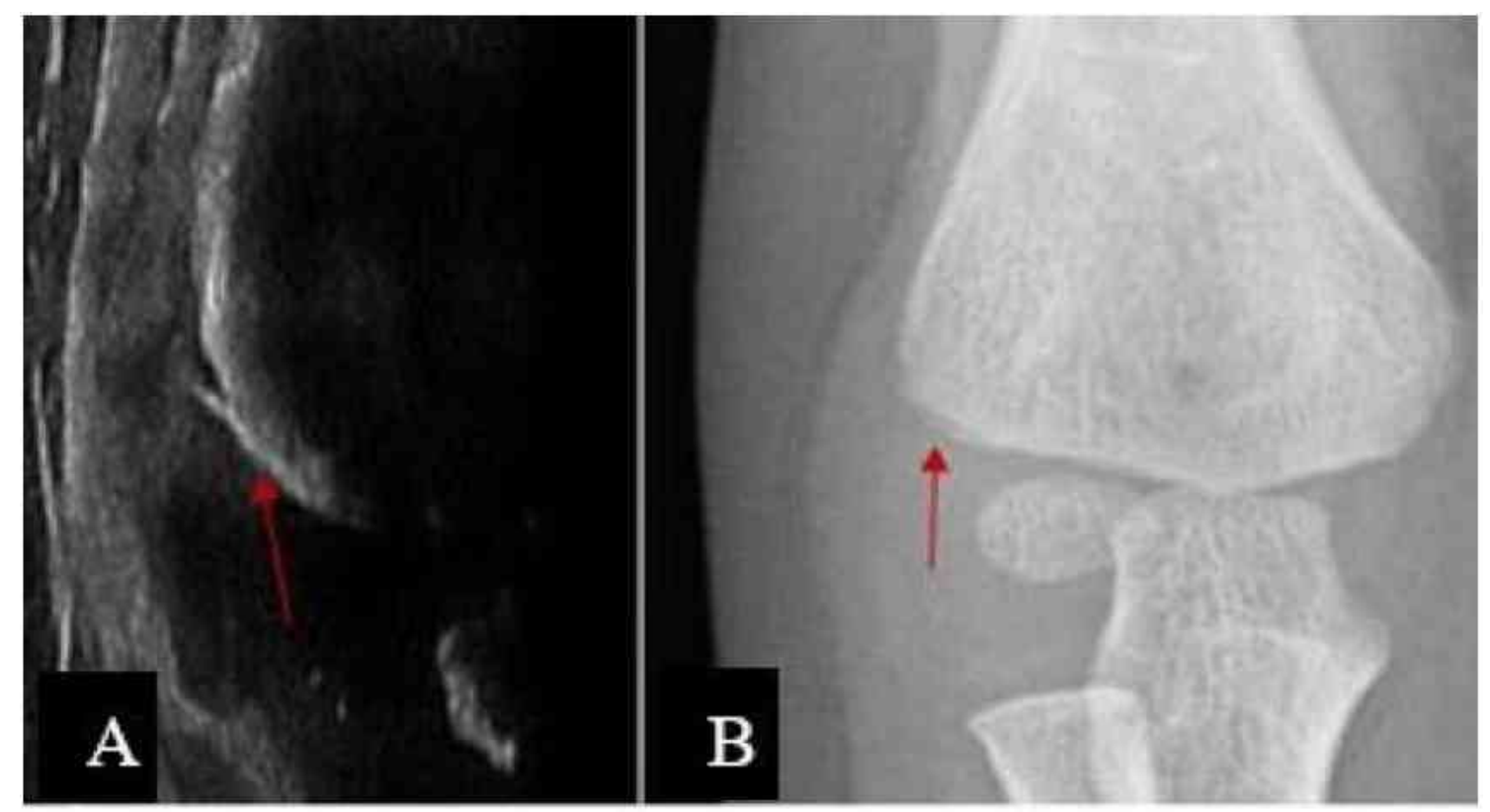

Figure 4. Anteroposterior X-ray and ultrasound picture of a radial condyle fracture in a 6 years old child. Signs of cortical disruption.

A: Cortical line disrupts in sonographic plane II. (arrow). B: A subtle cortical infraction can be seen on anteroposterior X-ray(arrow)
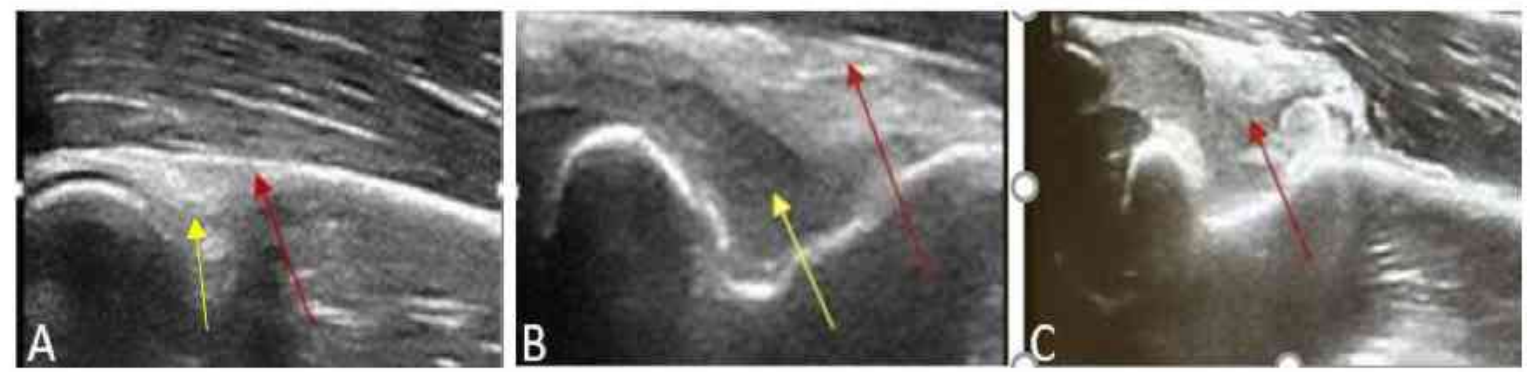

Figure 5. Sonographic signs of normal fat pad, elevated fat pad and lipohemarthros A: Normal fat pad sign (yellow arrow) Border of the fat pad is at the level of the dorsal humeral cortical line (red arrow) B: Elevated fat pad sign -fat pad border exceeds humeral line (red arrow), fluid is distinguishable (yellow arrow) $\mathbf{C}$ : Lipohaemarthros - there is an inhomogeneous indistinguishable mass in the fossa (red arrow) 


\section{II.2. Sonographic diagnosis of pulled elbow}

Between October 2016 and November 2017205 children were examined with the clinical suspect of PE. (Mean age: 2.3 years). Inclusion criteria were the typical clinical signs of PE: painful, motionless, extended or slightly flexed and pronated arm following a traumatic event under the age of six. We excluded children older than six years and patients with pronounced elbow swelling and initially flexed and supinated upper arm position. A two-plane point of care US examination was carried out at each patient immediately after history taking and primary physical survey. Examinations were done by two orthopaedic surgeons, and a properly trained orthopaedic resident in training.

US pictures were made by high-frequency linear probes. (Zonare ZS3 Ultrasound System, Mindray ${ }^{\circledR}, \mathrm{L} 15-5 \mathrm{~W}$ and L20-5W linear array transducers)

Imaging included a standard longitudinal central dorsal view over the olecranon fossa and a longitudinal ventral view over the radiocapitellar joint. (Figure 6.)

During examinations children lay on a bed, their arm was cautiously placed in an extended and pronated position for the ventral, and slightly flexed position for the dorsal view. We also examined the unaffected extremity to compare the results. Pictures were saved and the presence or absence of the dorsal sonographic elevated fat pad sign and the ventral intraarticular synovial fringe enlargement (SFE) were recorded. (Figure 7.)

Painless movement of the affected extremity within 15 minutes with or without a palpable click were considered as successful reduction manoeuvre and confirmation of the diagnosis. Patients with positive FPS and/or further pain and restriction of the movement were X-rayed and immobilised in an open plaster cast or brace. If symptoms have not ceased after 3-5 days, immobilisation time was prolonged and elbow X-rays were repeated in the $3 \mathrm{rd}$ week after injury. Fracture positivity on X-rays or callus formation on the 3 rd week radiographs ruled out PE.

Sonographic pictures were saved and analysed by a radiologist who was blinded to any patient-related clinical information. Interrater agreements of eFPS and SFE were calculated between the radiologist and the clinicians. We used Cohen's chance corrected kappa for calculation. We used GraphPad QuickCals ${ }^{\circledR}$ program to calculate the degree of agreement with Kappa. We used MEDCALC $\left({ }^{R}\right)$ diagnostic test evaluation calculator to determine the specificity, sensitivity, positive and negative predictive 
values of the two parameters both separately and together. We also estimated the rate of match of the presumed and final diagnosis.

Clinical approval of our diagnostic study was permitted by our Institutional Medical Board. An informed consent was obtained from the parents of all patients.
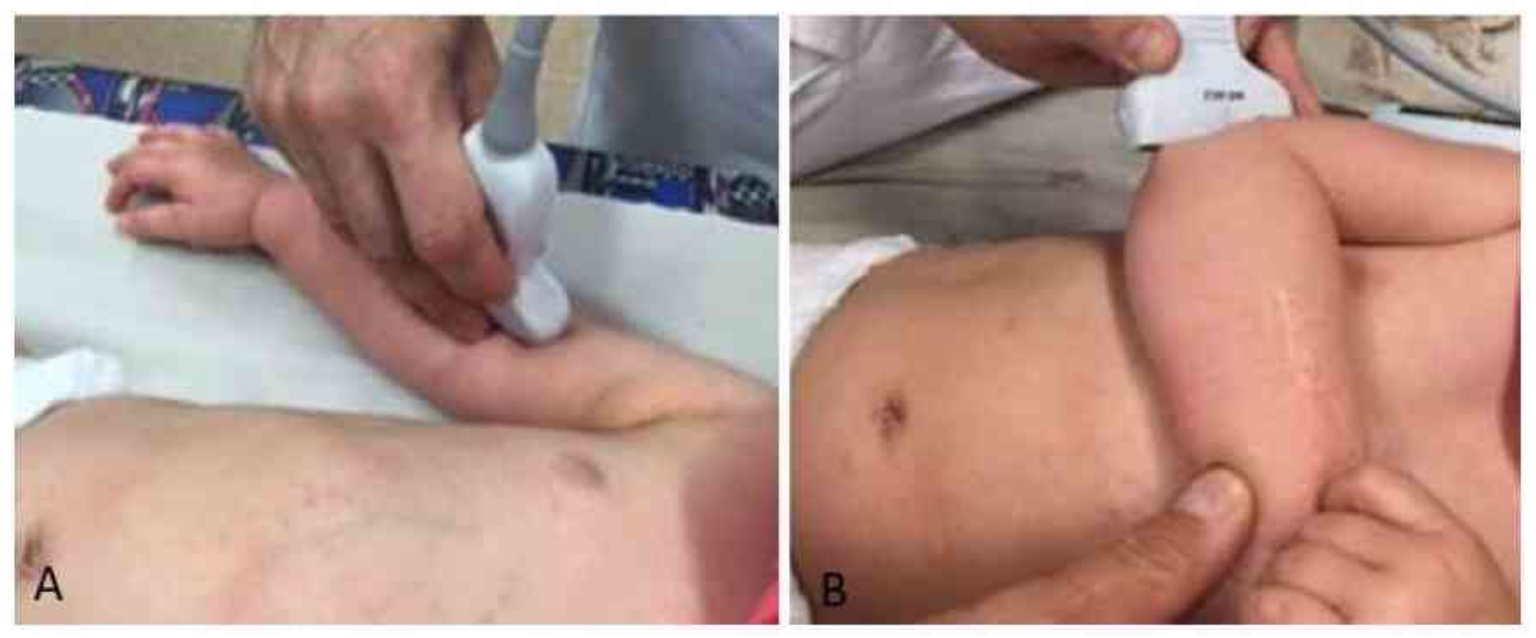

Figure 6. Transducer positions of two-point sonographic pulled elbow examinations

A: ventral longitudinal position above the radio capitellar joint $\mathbf{B}$ : dorsal longitudinal position above the olecranon fossa

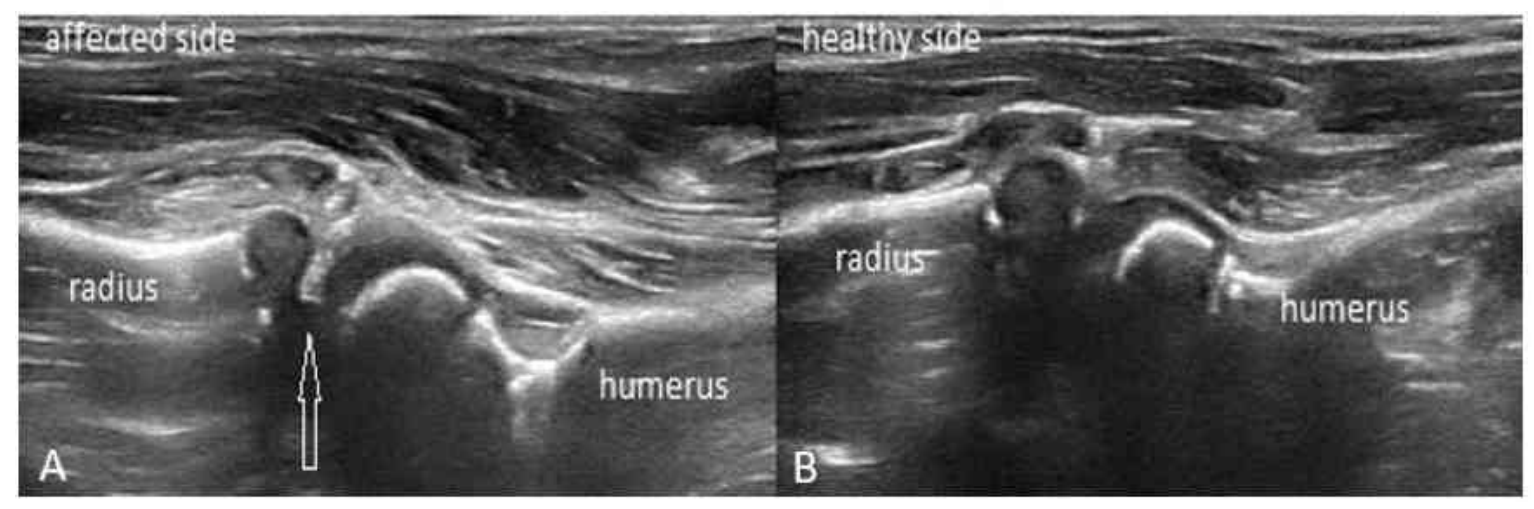

Figure 7. Ventral views of the sonographic two-point examination of pulled elbow. Synovial fringe enlargement.

A: A marked hyper-echoic structure in the radiocapitellar joint is the sign of synovial fringe enlargement. B: healthy side, no sign of interposed tissue. 


\section{III.3. Sonographic diagnosis of distal forearm fractures}

Between December 2011 and December 2015467 children (age 1-14) were enrolled in our study. Patients with isolated and closed distal forearm injury who needed standard two-plane wrist X-rays were included. We excluded children with open fractures and uncertain clinical symptoms when simultaneous indication of X-rays from other upper extremity joints were also needed.

Point of care US was carried out as a part of the primary physical survey. US examinations were executed by six properly trained doctors: two orthopaedic trauma residents, two orthopaedic surgeons, one paediatric surgeon, and one paediatric surgeon resident. We used a standardised protocol, which included six longitudinal sonographic planes: dorsal radial, dorsal ulnar, medial ulnar, lateral radial, ventral radial and ventral ulnar. (44) (Figure 8.)
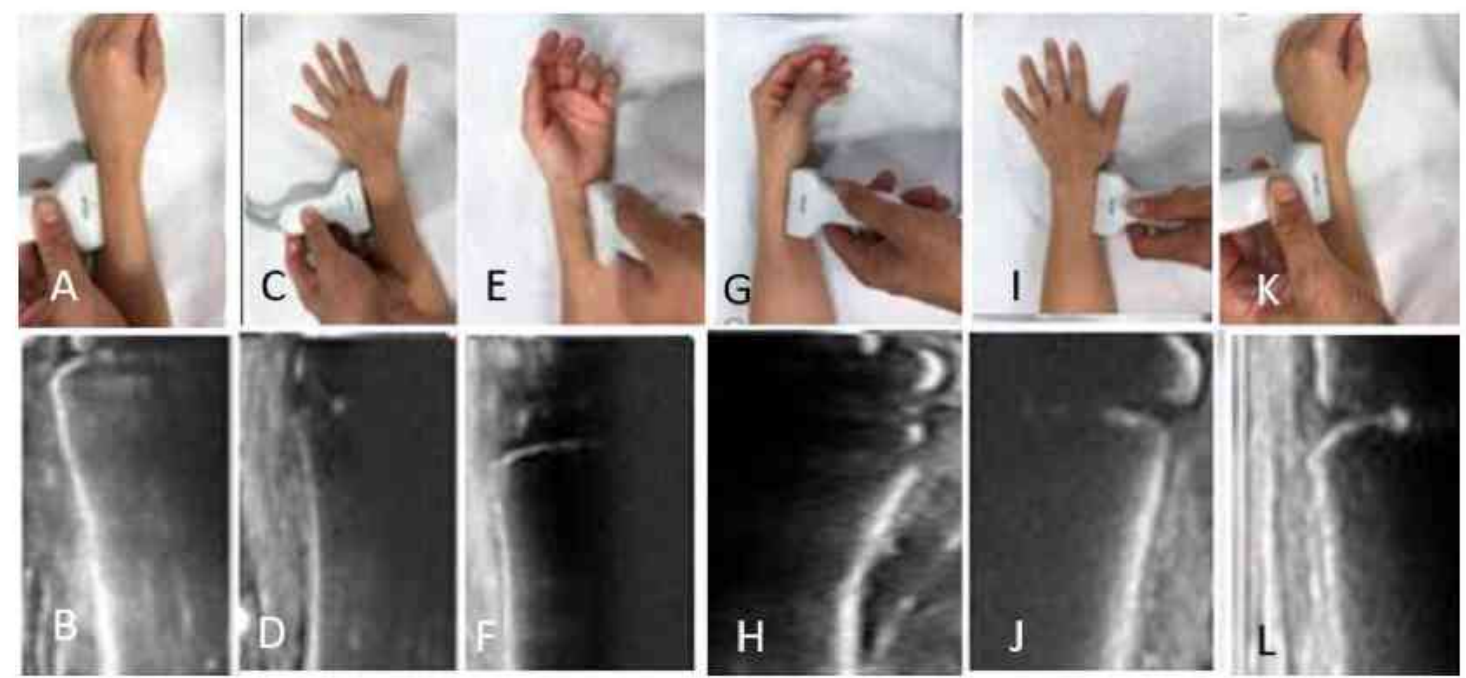

Figure 8. Transducer positions and sonographic pictures of the six-point ultrasound examination of paediatric distal forearm fracture $\mathbf{A}$ : transducer position in dorsal ulnar plane B: dorsal ulnar sonographic view $\mathbf{C}$ : transducer position in medial ulnar plane D: medial ulnar sonographic view $\mathbf{E}$ : transducer position in ventral ulnar plane $\mathbf{F}$ : ventral ulnar sonographic view $\mathbf{G}$ : transducer position in ventral radial plane $\mathbf{H}$ :ventral radial sonographic view: I: transducer position in lateral radial plane $\mathbf{J}$ : lateral radial sonographic view $\mathbf{K}$ : transducer position in dorsal radial plane $\mathbf{L}$ : dorsal radial sonographic view

US pictures were made by high-frequency linear probes. (Zonare ZS3 Ultrasound System, Mindray ${ }^{\circledR}$, L15-5W and L20-5W linear array transducers) Pictures were saved 
for further analyses. Immediately afterwards we made two plane X-rays from the affected side according to protocol. Images which have not met with standard requirements were excluded. US pictures and X-ray results were analysed and compared. We used MEDCALC $(\mathbb{R})$ diagnostic test evaluation calculator to determine the specificity, sensitivity, positive and negative predictive values. Clinical approval of our diagnostic study was permitted by our Institutional Medical Board. An informed consent was obtained from the parents of all patients.

\section{III.4. Elastic intramedullary nailing of distal radial fractures}

We reviewed retrospectively 104 patients who underwent operations due to severely displaced distal forearm or diametaphyseal radial fractures between November 2012 and December 2017. 84 children were treated with short, prebent double elastic nails. 20 patients were treated by single titanium nails and a special end seal. (Depuy $\mathbb{R}$, Synthes $($ $)$, TEN ${ }^{\circledR}$, End Cap $\left.{ }^{\circledR}\right)$ Indications for surgery included closed and unstable distal radius fractures with severe displacement and shortening. We excluded open fractures, physeal injuries, and pathological fractures. All procedures were performed under general anaesthesia and $\mathrm{C}$-arm image intensifier control. A single-shot antibiotic prophylaxis was routinely used. All children were treated by six surgeons experienced both in the ESIN and percutaneous pinning technique. The parents were informed about other treatment options. A postoperative mobilisation program has begun in the first day and a short removable splint has been applied.

Standard two-plane X-ray images were made in the postoperative first, $4^{\text {th }}, 12^{\text {th }}$ and $24^{\text {th }}$ weeks. Angulation of the radial epiphysis was measured in coronal and sagittal planes. We considered reduction perfect if radial articular deviations were below 5 degrees both in anteroposterior and lateral planes. Residual angulation between 5 and 15 degrees was considered good. Angulations between 15 and 30 degrees were graded as acceptable under the age of 12 at boys and under the age of 10 at girls. Greater than 30 degrees of angulations or deviations out of the expected remodelling range in older children were considered as bad. Nails were removed at 6 to 36 weeks after the operation in general or in local anaesthesia. 
Our method is a modification and special application of the conventional and existing ESIN technique. Clinical application of the technique has been accepted and permitted by our medical review board and by the Hungarian Paediatric Trauma Committee and by the Hungarian Paediatric Surgery Committee. Possible benefits, risks, and complications, along with other methods, were explained to all parents of each child, and an informed consent was obtained from them. Clinical approval of our retrospective study was permitted by our Institutional Medical Board.

\section{III.4/1. Operative technique - short double intramedullary nailing}

Patients are under general anaesthesia. The arm is in a pronated and extended position and placed on a fluoroscopically translucent table. The first step is closed reduction under image intensifier. If reduction cannot be achieved by single manual manipulation, a 2 to $3 \mathrm{~mm}$ diameter blunt ended Kirschner-wire (K-wire) or elastic nail is inserted to the fracture gap from a dorsal stab incision. Using the pin as a lever arm, the distal fragment is raised up and slid forward onto the proximal end. (Figure 9.)

After successful reduction, we determine the insertion points of the short elastic nails. The first point is the dorsal site of distal radius, the area of Lister tubercle, just proximal to the physeal line of the radius. After skin incision, we gently dissect the soft tissues, and we open the medullary canal with an awl. A "c"-shaped prebent short and relatively thick ( $8-12 \mathrm{~cm}$ long and $2.5-3.5 \mathrm{~mm}$ diameter) titanium elastic nail is inserted into the distal medullary canal of the radius. The nail is gently moved forward along its curvature until its distal end enters the medullary canal of the proximal fragment. A moderate pressing force is applied, and the nail tip becomes impacted. In this position, the convex side of the nail faces the fracture line of the anterior cortex when observing from a lateral view. If the position of the first nail is optimal, we determine the entry point for the second one. It is the distal radial site of the radius, just proximal to the growth plate.

The second nail is usually thinner $(2-2.5 \mathrm{~mm}$ in diameter) and prebent to a "c"-form shape. Similarly, to the technique described above, this nail is advanced forward along a radial-ulnar and distal to proximal curvature. 


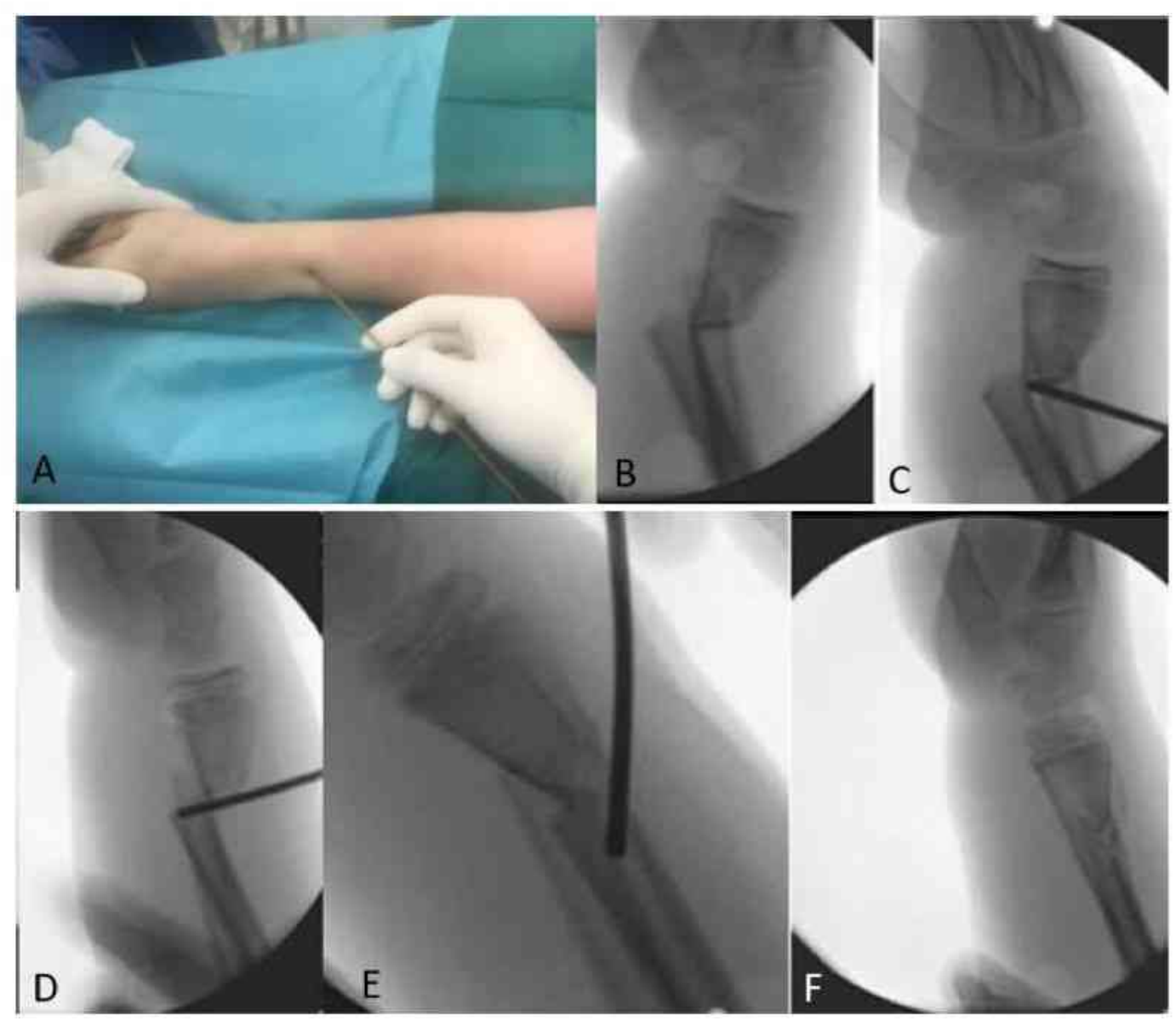

Figure 9. Percutaneous reduction of severely displaced distal paediatric forearm fracture

A: A blunt ended K-wire inserted into the fracture gap (intraoperative picture) B-E: using the $\mathrm{K}$-wire as a lever arm, the distal end of the radius is replaced to the proximal fragment (Intraoperative X-rays by image intensifier) F: although the reduction is perfect, fixation is mandatory because the fracture is unstable

After reaching the medullary canal of the proximal fragment, the nail is pushed further with a controlled force, until tightness is achieved. Observing from an anteroposterior view, the convex side of the nail faces the ulnar cortex of the radius (Figure 10.) If the prebent curve of the short nail is not sufficient (the " $\mathrm{c}$ " shape is too flat), the end of the nail will get stuck in the ventral cortex. An overbent nail, however, cannot be inserted into the proximal medullary canal. In this situation, the nail is pulled back, and the degree of the curvature is corrected. By pushing forward a nail in a bad position, an additional iatrogenic ventral or dorsal cortical fracture can occur, so it is forbidden to use uncontrolled force during nail insertion. 


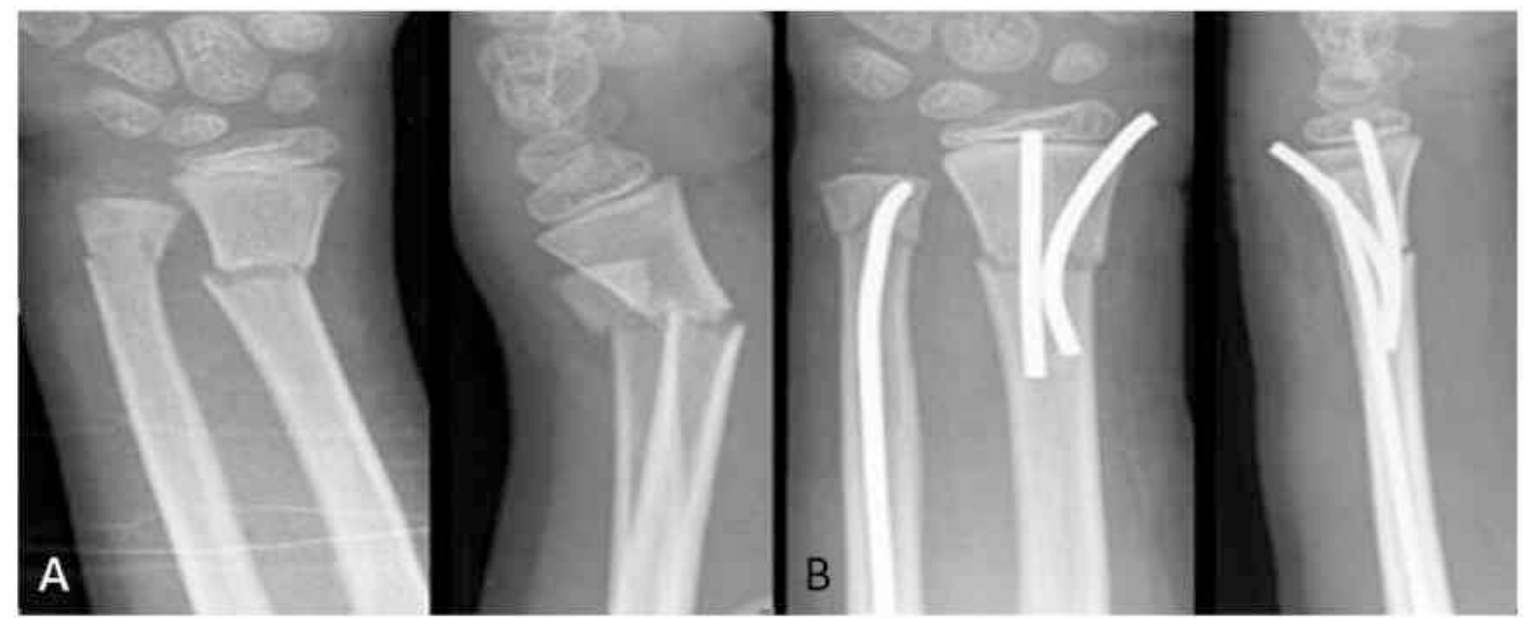

Figure 10. Pre- and postoperative X-rays of distal paediatric forearm fracture treated by double elastic nailing

A: Anteroposterior and lateral X-rays of an unstable distal metaphyseal forearm fracture of a 9 years old child B: Radial fracture is stabilised by short, double elastic nailing. Ulnar fracture is also stabilised by conventional anterograde elastic nailing to increase stability.

\section{III.4/2. Operative technique - short single elastic nailing with End Cap $\left({ }^{\circledR}\right.$}

The initial steps of the surgical technique are the same as in the double nailing. Operation should be carried out by using a pneumatic tourniquet for good visualisation and protection of the tendons during implant insertion. This requires approximately one and half $\mathrm{cm}$ wide transverse incision. The insertion point of the nail should be placed proximally to the physis in the dorsal midline or on the lateral side of the radius. It is not suggested introducing the implant through the Lister's tubercle because the end seal has a greater diameter than the elastic nail and in the case of bad positioning the EPL may be damaged. The prebent, short "c"-shaped elastic nail is inserted to the radius. Convexity of the nail faces anteriorly. After reduction and implant positioning, the end of the nail should be cut off to leave a free $0.5-1 \mathrm{~cm}$ long section out of the bone. End Cap ${ }^{\circledR}$ should be applied after clear visualisation and protraction of the surrounding tendons. End Cap ${ }^{\circledR}$ cannot press or touch the physeal plate. Skin is closed above the smooth end of the end seal. For stable fixation the threads of the seal should be attached to the bone. If the implant is very protruding or cause tension of the skin, it is suggested 
to remove it, and cut the nail shorter or push it deeper. After correction, the seal can be repositioned.

A conventional anterograde ulnar elastic nailing should be also carried out if there is a concurrent ulnar fracture. Ulnar nailing is suggested in both techniques. (114) Nailing of the ulna is suggested after radial stabilisation. (Figure 11)

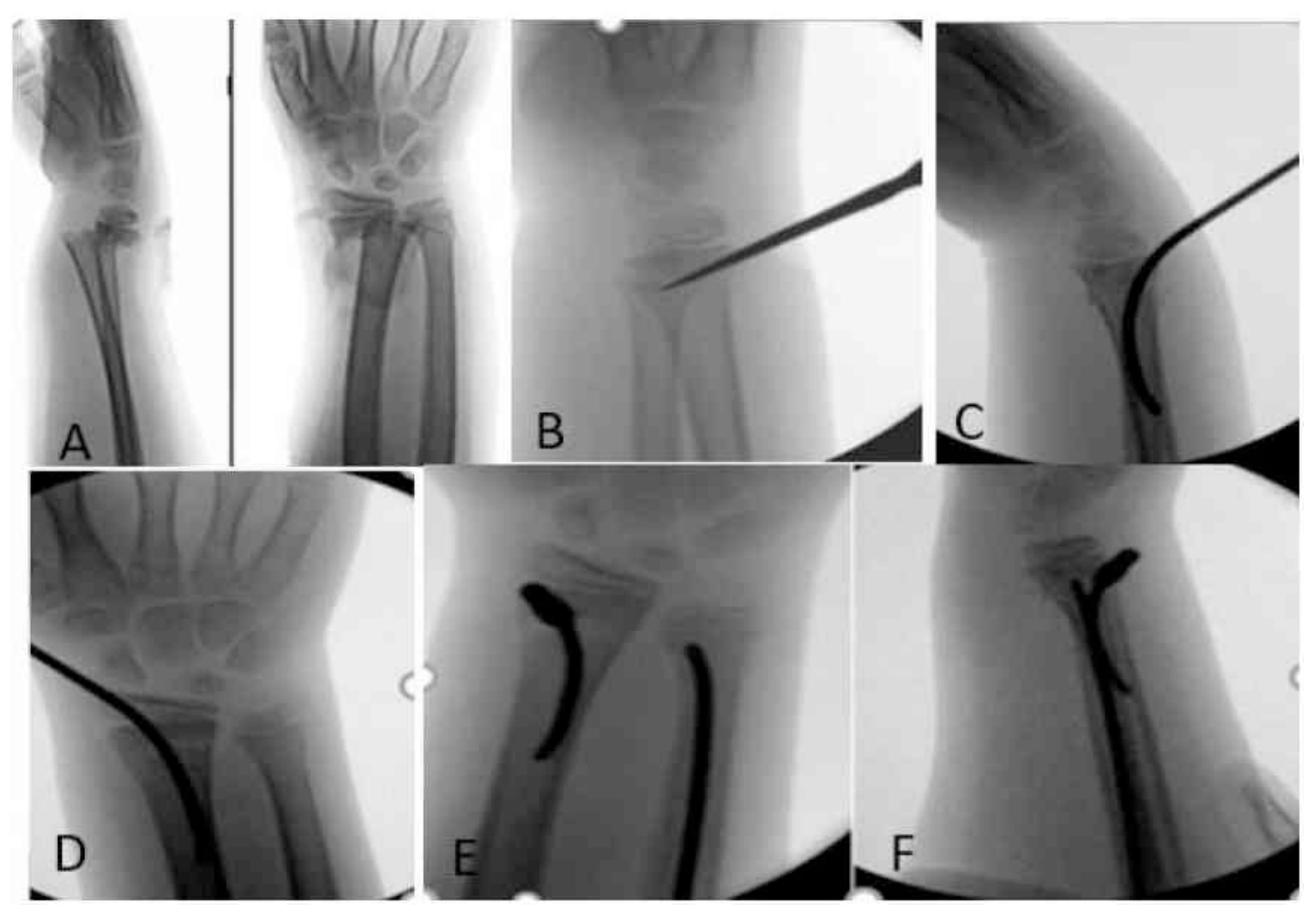

Figure 11.

Elastic short intramedullary nailing with End Cap $(\mathbb{R}$

A: Severely displaced distal forearm fracture of a five years old child. Metaphyseal part of the fracture is very small. B: After reduction the medullary canal is opened just proximal to the physeal plate. C-D: A thick ( $3 \mathrm{~mm}$ diameter) prebent nail is inserted into the medullary canal. Position of the nail is controlled by lateral (C)and anterior (D) X-rays. E-F: Ulnar fracture is also stabilised by conventional anterograde nailing. End of the radial nail is sealed by the End Cap $\mathbb{R}$. Reduction is checked by anterior (E) and lateral (F)X-rays. 


\section{III.4/3. Postoperative care}

For the first 1 to 2 weeks a short, removable splint is applied. The purpose of the splint is mostly the postoperative pain relief. After the splint is removed, wrist and forearm movements with full range of motion can be started. Hard physical work, sport activity is recommended from the postoperative sixth week when X-rays confirm callus formation.

\section{III.5. Intraoperative sonography of radial elastic stable intramedullary nailing}

We performed cadaveric examinations on six human adults. EPL and Lister's tubercle was visualised by high frequency $(20 \mathrm{Mhz})$ ultrasound imaging.

. (Zonare ZS3 Ultrasound System, Mindray ${ }^{\circledR}$, L20-5W linear array transducer)

After sonographic determination of the insertion points, we positioned an elastic nail through Lister's tubercle according to standard dorsal technique. Position of the EPL relative to the elastic nail was examined from transverse and longitudinal planes. We bent the extraosseal end of the nail in a slight radial direction and cut beneath the skin in a maximally palmar-flexed wrist position. This was followed by preparation of the area and comparing the sonographic and anatomic findings.

Cadaveric dissections all correlated with ultrasonographic findings: distance of EPL and nail was median $0.5 \mathrm{~cm}$ (range: $4.4-5.2 \mathrm{~cm}$ ) clinically, and $0.48 \mathrm{~cm}$ (range: 0.44 $0.5 \mathrm{~cm}$ ) measured in US. There was no tendon damage, obstruction or friction.

Following our cadaveric experience, we began using intraoperative ultrasound during elastic nailing of paediatric radial fractures.

A written informed consent was obtained from the parents of all patients. Between January 2015 and November 2016, 77 radial fractures were operated by dorsal entry elastic nailing under US guidance. Inclusion criteria were children with closed and displaced radial or forearm fractures which were candidates for operative ESIN technique. We excluded children with closed growth plates, open fractures and comminuted fractures which could not be stabilised by intramedullary nailing. Patients' age was between 4 and 15 years and had closed and displaced radial or forearm fractures with open growth plates. 
We used aseptically isolated high frequency linear probes and sterile gel for the intraoperative technique. First, we determined the insertion point. After skin incision and soft tissue separation, we targeted the radial slope of Lister's tubercle with a sharp Kirschner wire. After we pressed the wire softly to the bone, we checked its position with image intensifier and IOP-US. Medullary canal opening with a sharp awl was also monitored by US and an elastic nail of 2 to $2.5 \mathrm{~mm}$ diameter was inserted.

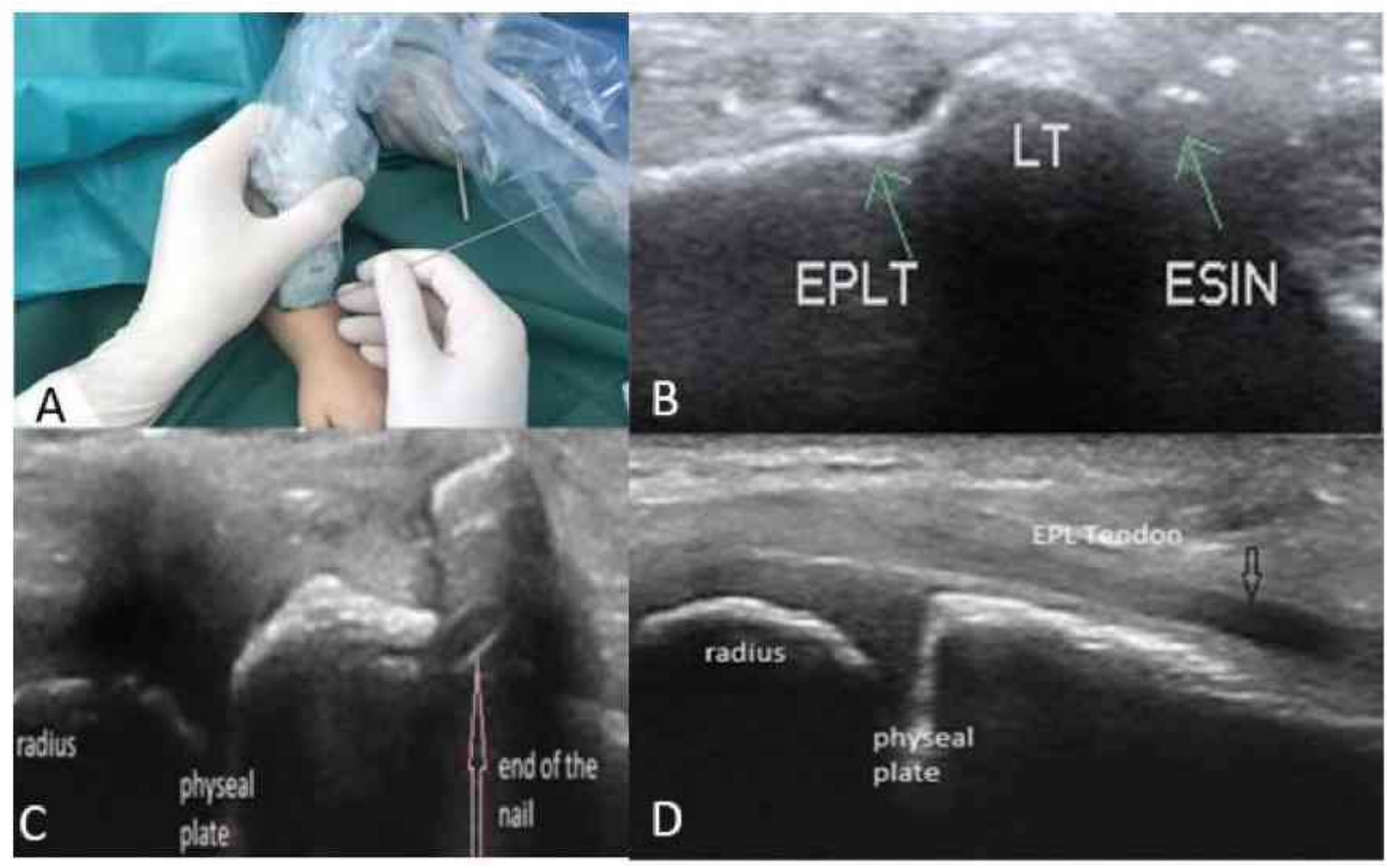

Figure 12. Sonography -assisted aiming of the radial side of Lister's tubercle and intraoperative ultrasound views of the dorsal entry elastic nailing of the radius A: Lister's tubercle is aimed by a K-wire under sonographic checking. Transducer is aseptically isolated $\mathbf{B}$ : Transverse intraoperative sonographic view of the nail and tendon $\mathbf{C}$ : Longitudinal intraoperative sonographic view of the radius and the nail's extraosseal end. Tendon is not visualised in this plane. D: Longitudinal intraoperative sonographic view of the radius and the EPL tendon. (arrow) Nail is not visualised in this plane. $\mathrm{EPL}=$ extensor pollicis longus tendon, $\mathrm{ESIN}=$ elastic stable intramedullary nail, $\mathrm{LT}=\mathrm{Lister}$ 's tubercle

Operative technique and fracture reduction were made according to protocol. After cutting the end of the nail, we rechecked its position relatively to Lister's tubercle. EPL 
has been also checked in longitudinal and transverse plane, we analysed its relation to the extraosseal part of the nail. (Figure12) Continuity of the tendon has been checked by dynamic examination while passively flexing and extending the wrist and the thumb. In patients where we found that the nail was too close to the tendon or the EPL got stock during dynamic assessment), we corrected its position. Procedures were executed by 2 orthopaedic surgeons experienced in ESIN technique and with musculoskeletal US qualifications.

\section{Results}

\section{IV.1. Sonographic diagnosis of elbow fractures}

Out of the 365 children we identified 165 positive findings $(45,2 \%)$ by primary $\mathrm{X}$ rays.

We found $29(17.5 \%)$ radial condylar, 84(50.9\%) supracondylar humeral, $19(11.5 \%)$ proximal radial, 7 (4.2\%) proximal ulnar, $14(8.4 \%)$ medial epicondylar fractures, 3 $(1.8 \%)$ fractures with joint dislocations, $2(1.2 \%)$ joint dislocations without fractures, and $7(4.2 \%)$ fracture combinations which affected two or more bones. We did not find injuries among these patients that we could not categorised into one of these groups. All fractures or dislocations had at least one positive finding out of the five planes. 112 fractures showed positivity in at least two planes.

Out of the fracture combinations 6 showed cortical abnormality in two, one in three planes. Sonographic FPS was negative in one radial condylar, two proximal radial and two medial epicondylar fractures. All these fractures showed positivity in at least one other longitudinal plane.

There was no sign of cortical abnormality in plane II.-V. at 3 medial epicondylar, at 24 supracondylar fractures and at the elbow dislocations. All these injuries showed eFPS or $\mathrm{LH}$ in ultrasound.

All radial condylar, proximal radial and proximal ulnar fractures showed at least one positive finding in plane II.-V.

12 children had sonographic FPS positivity without X-ray abnormality. Out of these patients 7 had a marked LH positivity, and 5 children showed mildly elevated FPS in 
US. The LH positive elbows all showed callus formation on follow-up X-rays. These injuries were considered as occult fractures.

The other five patients with mildly elevated FPS have not showed callus formation and were considered as elbow contusions.

7 other children with primary negative X-rays had cortical abnormality in one of the II$\mathrm{V}$ planes without positive FPS. These patients have not showed abnormality on follow up X-rays.

Summing up a total of twelve pseudo-positives findings were identified. No pseudonegativity was detected using the five examining points.

Evaluating the sonographic dorsal FPS as a sole parameter for fracture detection we found sensitivity: 0,97 , specificity: 0,97 , positive predictive value: 0,97 , negative predictive value: 0,97 .

Evaluating the effectivity of the II.-V. planes we calculated sensitivity 0,85 specificity 0.96 positive predictive value: 0.95 , negative predictive value 0.87 .

The overall values of the five planes were the following: specificity0.97 sensitivity 1 , positive predictive value 0.97 negative predictive value: 1

Interrater agreements on the cortical plane abnormality were considered good and very good. (Kappa $=0.79,0,81,0,79)$ Agreements on differentiation of eFPS, normal FPS or LH in sonographic pictures were very good in all cases. (Kappa $=0,83,0,86,0,82$ ) Although we have not observed any pseudo-negative findings, the exact identification of the type of the injury only by US was possible in 113 cases. (68\%) (Table I.-III.)

\begin{tabular}{|c|c|c|c|}
\hline & & Cortical plane abnormality & FPS \\
\hline $\begin{array}{l}\text { Examiner } \\
\text { radiologist }\end{array}$ & I. and & 0.76 & 0.93 \\
\hline $\begin{array}{l}\text { Examiner } \\
\text { radiologist }\end{array}$ & II. and & 0.74 & 1 \\
\hline $\begin{array}{l}\text { Examiner } \\
\text { radiologist }\end{array}$ & III and & 0.79 & 0.93 \\
\hline
\end{tabular}

Table I. Interrater agreements of sonographic abnormalities in the five-point elbow fracture ultrasound diagnostics (Kappa values: 0.81-1: very good, 0.61-0.80: good, $0.41-0.60$ moderate, $0.21-0.40$ fair, $0-0.20$ 


\begin{tabular}{|c|c|c|c|c|c|}
\hline $\begin{array}{l}\mathbf{N}=177 \\
\text { True positive }=165 \\
\text { pseudo-positive }=12 \\
\text { pseudo-negative }=0\end{array}$ & $\begin{array}{l}\text { Positive in } \\
\text { Plane I. } \\
\text { Dorsal elevated } \\
\text { fat pad sign } \\
\text { (EFPS)/ } \\
\text { lipohemarthros(LH) }\end{array}$ & $\begin{array}{l}\text { Positive } \\
\text { in } \\
\text { Plane II. } \\
\text { Distal } \\
\text { lateral } \\
\text { humeral } \\
\text { column }\end{array}$ & $\begin{array}{l}\text { Positive } \\
\text { in Plane } \\
\text { III. } \\
\text { Distal } \\
\text { medial } \\
\text { humeral } \\
\text { column. }\end{array}$ & $\begin{array}{l}\text { Positive in } \\
\text { Plane IV. } \\
\text { Proximal } \\
\text { radial plane }\end{array}$ & $\begin{array}{l}\text { Positive } \\
\text { in } \\
\text { Plane V. } \\
\text { Proximal } \\
\text { ulnar } \\
\text { plane }\end{array}$ \\
\hline $\begin{array}{l}\text { Supracondylar } \\
\text { humeral fractures } \\
n=84\end{array}$ & $\begin{array}{l}84 \\
\text { EFPS }=6 \\
\text { LH }=78\end{array}$ & 37 & 28 & 0 & 0 \\
\hline $\begin{array}{l}\text { Radial condylar fractures } \\
\mathrm{n}=29\end{array}$ & $\begin{array}{l}28 \\
\text { EFPS }=6 \\
\text { LH }=22\end{array}$ & 29 & 0 & 0 & 0 \\
\hline $\begin{array}{l}\text { Proximal radial fractures } \\
\mathrm{n}=19\end{array}$ & $\begin{array}{l}17 \\
\text { EFPS }=14 \\
\mathrm{LH}=3\end{array}$ & 0 & 0 & 19 & 0 \\
\hline $\begin{array}{l}\text { Proximal ulnar fractures } \\
n=7\end{array}$ & $\begin{array}{l}7 \\
\text { EFPS }=7 \\
\mathrm{LH}=0\end{array}$ & 0 & 0 & 0 & 7 \\
\hline $\begin{array}{l}\text { Fractures with } \\
\text { dislocations } \\
\mathrm{n}=3\end{array}$ & $\begin{array}{l}3 \\
\mathrm{LH}=3 \\
\mathrm{EFPS}=0\end{array}$ & 0 & 2 & 2 & 1 \\
\hline $\begin{array}{l}\text { Medial epicondylar } \\
\text { fractures } \\
n=14\end{array}$ & $\begin{array}{l}11 \\
\text { EFPS }=8 \\
\text { LH }=3\end{array}$ & 0 & 11 & 0 & 0 \\
\hline $\begin{array}{l}\text { Dislocations } \\
\mathrm{n}=2\end{array}$ & $\begin{array}{l}2 \\
\mathrm{EFPS}=0 \\
\mathrm{LH}=2\end{array}$ & 0 & 0 & 0 & 0 \\
\hline $\begin{array}{l}\text { Fracture combinations } \\
\mathrm{n}=7\end{array}$ & $\begin{array}{l}7 \\
\text { EFPS }=0 \\
\text { LH }=7\end{array}$ & 2 & 2 & 7 & 7 \\
\hline $\begin{array}{l}\text { Pseudo-positive cases } \\
\mathrm{n}=12\end{array}$ & $\begin{array}{l}5 \\
\text { EFPS }=5 \\
\text { LH }=0\end{array}$ & 5 & 2 & 0 & 0 \\
\hline
\end{tabular}

Table II. Number of detected abnormalities of different elbow fractures in individual sonography planes LH: lipohemarthrosis eFPS: elevated fat pad sign 


\begin{tabular}{|l|l|l|l|}
\hline & Sonographic FPS & Cortical abnormality & $\begin{array}{l}\text { Sonographic } \\
\text { FPS+cortical }\end{array}$ \\
\hline $\begin{array}{l}\text { Sensitivity } \\
\text { Specificity }\end{array}$ & $96.49 \%$ & $85.05 \%$ & $100 \%$ \\
\hline $\begin{array}{l}\text { Positive } \\
\text { predictive value }\end{array}$ & $97.56 \%$ & $96.62 \%$ & $97.56 \%$ \\
\hline $\begin{array}{l}\text { Negative } \\
\text { predictive value }\end{array}$ & $97.09 \%$ & $95.93 \%$ & $97.06 \%$ \\
\hline $\begin{array}{l}\text { Positive } \\
\text { likelihood ratio }\end{array}$ & 39.56 & $87.34 \%$ & $100 \%$ \\
\hline $\begin{array}{l}\text { Negative } \\
\text { likelihood ratio }\end{array}$ & 0.04 & 25.15 & 41.00 \\
\hline Accuracy & $97.07 \%$ & 0.15 & 0.00 \\
\hline
\end{tabular}

Table III. Diagnostic values of the sonographic fat pad sign and cortical plane abnormalities of the paediatric five-point elbow fracture ultrasound

\section{IV.2. Sonographic diagnosis of pulled elbow}

Out of the 205 children $196(95,6 \%)$ proved to have pulled elbow and $9(4.39 \%)$ fractures. These latter injuries were type I. supracondylar humerus fractures by Gartland classification.

Sonographic SFE sign was identifiable in $156(76 \%)$ cases. eFPS was negative in all but one PE cases. 7 children (3.41\%) had type I.SCH fractures which were visible in the first X-rays, and two children had occult fractures, $(0.97 \%)$ which were proved by the evidence of callus formation on the follow-up X-rays. These children all had positive FPS and negative findings for SFE sign.

Interrater agreement between the examiners and the radiologist showed good results in the evaluation of SFE, $(0,76,0,74,0,79)$ whereas excellent $(0.939,1,0.939)$ in the interpretation of FPS.SFE showed $83 \%$ sensitivity and $100 \%$ specificity, $100 \%$ positive predictive value and $18 \%$ negative predictive for PE as a sole parameter. Presence of the FPS proved to result $99 \%$ sensitivity and $100 \%$ specificity, $100 \%$ positive predictive value and $90 \%$ 
negative predictive value. Evaluating the two parameters together both sensitivity, specificity, NPV and PPV were 100\%. (Table IV-VI.)

\begin{tabular}{|l|r|r|}
\hline \multicolumn{1}{|c|}{$\mathbf{n = 2 0 5}$} & $\begin{array}{c}\text { Pulled elbow } \\
(\mathrm{n}=196)\end{array}$ & $\begin{array}{c}\text { Fractures } \\
(\mathrm{n}=9)\end{array}$ \\
\hline \begin{tabular}{l|r|} 
Synovial fringe positivity \\
Sonographic fat pad sign positivity
\end{tabular} & 156 & 0 \\
\hline $\begin{array}{l}\text { Sonographic fat pad positivity and synovial fringe } \\
\text { negativity }\end{array}$ & 0 & 9 \\
\hline $\begin{array}{l}\text { sonographic fat pad negativity and synovial fringe } \\
\text { negativity }\end{array}$ & 40 & 0 \\
\hline $\begin{array}{l}\text { Sonographic fat pad and synovial fringe positivity } \\
\text { Sonographic fat pad negativity and synovial fringe }\end{array}$ & 1 & 0 \\
\hline positivity & 155 & 0 \\
\hline
\end{tabular}

Table IV. Sonographic findings of pulled elbows and supracondylar humeral fractures

\begin{tabular}{|c|c|c|c|}
\hline & Sonographic eFPS & $\begin{array}{l}\text { Synovial fringe } \\
\text { enlargement }\end{array}$ & $\begin{array}{l}\text { Sonographic } \\
\text { FPS+positive } \\
\text { SFE }\end{array}$ \\
\hline Sensitivity & $99.49 \%$ & $83.05 \%$ & $100 \%$ \\
\hline Specificity & $100 \%$ & $100 \%$ & $100 \%$ \\
\hline $\begin{array}{l}\text { Positive predictive } \\
\text { value }\end{array}$ & $100 \%$ & $100 \%$ & $100 \%$ \\
\hline $\begin{array}{l}\text { Negative predictive } \\
\text { value }\end{array}$ & $90.00 \%$ & $18.37 \%$ & $100 \%$ \\
\hline $\begin{array}{l}\text { Positive likelihood } \\
\text { ratio }\end{array}$ & - & - & - \\
\hline $\begin{array}{l}\text { Negative likelihood } \\
\text { ratio }\end{array}$ & 0.01 & 0.17 & 0.00 \\
\hline Accuracy & $99.51 \%$ & $83.67 \%$ & $100 \%$ \\
\hline
\end{tabular}

Table V. Diagnostic values of the two-plane sonographic method of pulled elbow SFE: synovial fringe enlargement, eFPS: elevated fat pad sig 


\begin{tabular}{|l|l|l|}
\hline & SFE & eFPS \\
\hline $\begin{array}{l}\text { Examiner I. } \\
\text { and radiologist }\end{array}$ & 0.76 & 0.93 \\
\hline $\begin{array}{l}\text { Examiner II. } \\
\text { and radiologist }\end{array}$ & 0.74 & 1 \\
\hline $\begin{array}{l}\text { Examiner III } \\
\text { and radiologist }\end{array}$ & 0.79 & 0.93 \\
\hline
\end{tabular}

Table VI. Interrater agreement of the evaluation synovial fringe enlargement (SFE)and sonographic elevated fat pad sign. (eFPS)

(Kappa values: 0.81-1: very good, 0.61-0.80: good,0.41-0.60 moderate,0.21-0.40 fair, 00.20 poor)

\section{3. Sonographic diagnosis of distal forearm fractures}

Out of 467 children we found $270(57.8 \%)$ positive and $197(42.2 \%)$ negative results for distal forearm fracture. Sonography has shown 263 positive and 204 negative results. The fractures were divided into three groups based on clinical significance.

Children without the need of further clinical intervention were divided into group I. Injuries which needed only reduction manoeuvre were divided into group II. Unstable severely displaced fractures which needed operative intervention were divided into group III.

We also investigated the distribution of pseudo-negative and pseudo-positive cases in each group.

We considered the results pseudo-negative when sonography has not confirmed the presence of any fractures which were detectable on X-rays. All these results $(n=7)$ were found in group I. Fractures which have been confirmed only by ultrasound were considered as pseudo-positive. Such results $(n=7)$ were found also only in the group I. (Table VII.) Based on our results we found sensitivity 0.97 and specificity 0.96 for sonographic fracture detection in the area of distal paediatric forearm. (Table VII-VIII.) 


\begin{tabular}{|l|c|c|c|}
\hline $\begin{array}{l}\text { Distribution of fractures by } \\
\text { significance (n= 270) }\end{array}$ & $\begin{array}{c}\text { Positive on } \\
\text { X-ray }\end{array}$ & $\begin{array}{r}\text { Pseudo-negative } \\
\text { on US }\end{array}$ & $\begin{array}{c}\text { Pseudo-positive } \\
\text { on US }\end{array}$ \\
\hline $\begin{array}{l}\text { Group I. } \\
\begin{array}{l}\text { Fractures without the need intervention } \\
\text { (epiphyseolysis or torus fractures } \\
\text { without displacement) }\end{array}\end{array}$ & $\begin{array}{c}\mathrm{n}=7 \\
\mathrm{n}=7\end{array}$ \\
\hline $\begin{array}{l}\text { Group II. Fractures with angulation or } \\
\text { moderate displacement which need } \\
\text { reduction }\end{array}$ & $\begin{array}{l}\mathrm{n}=52 \\
(20 \%)\end{array}$ & $\mathrm{n}=0$ & $\mathrm{n}=0$ \\
\hline $\begin{array}{l}\text { Group III. Fractures with severe } \\
\text { displacement which need operative } \\
\text { intervention }\end{array}$ & $\mathrm{n}=30$ & $\mathrm{n}=0$ & $\mathrm{n}=0$ \\
\hline
\end{tabular}

Table VII. Distribution of pseudo -negative and pseudo-positive cases in the three groups of patients examined by distal forearm fracture sonography

\begin{tabular}{|l|l|}
\hline $\begin{array}{l}\text { Distal forearm fracture ultrasound in } \\
\text { children }\end{array}$ & $\mathrm{n}=467$ \\
\hline Sensitivity & $\mathbf{9 7 . 4 7 \%}$ \\
\hline Specificity & $96,56 \%$ \\
\hline Positive predictive value & $97.47 \%$ \\
\hline Negative predictive value & $96.57 \%$ \\
\hline Negative likelihood ratio & 0.03 \\
\hline Positive likelihood ratio & 28.41 \\
\hline Accuracy & $97.09 \%$ \\
\hline
\end{tabular}

Table VIII. Diagnostic values of paediatric distal forearm fracture ultrasound

\section{IV.4. Short elastic intra-medullary nailing of distal forearm fractures}

None of the 104 cases required reoperation. Implant migration did not occur. No deep septic complication was observed.

We detected a superficial skin infection at 3 children in the double nailed group. Inflammatory signs have disappeared after the nails had been removed. All fractures have been stably consolidated at the time of nail removal. 
9 children had moderate skin irritation caused by the ends of the implants. After removing the nails these symptoms completely disappeared. No skin irritation was observed in children who had end seal protection.

No tendon or nerve injury was found in any of the groups. All but one of the implants were removed between the sixth and twenty-fourth postoperative weeks. In one patient one of the nails had been placed too deep (below the level of the cortical bone) so we could not remove it. The average follow-up time was 9 months to 4 years. Each child has healed with full function, no growth disturbance or movement limitation have developed.

Brace treatment required an average of 12 days. (1-4 weeks)

Analysing the X-rays made at the checking times the following results were obtained: In the group whose members were treated by double nailing, anatomic reduction was found in 70 children, good in 13 children and acceptable in 1 child. Out of 20 patients treated by single elastic nail and End Cap ${ }^{\circledR} 13$ showed anatomic and 7 good reductions.

X-rays on the fourth postoperative week showed slightly worse results in the double nailed group: classification was changed from anatomic to good in 4 children, from good to acceptable in three children and 1child has been graded to bad category due to moderate secondary displacement. Children with single nail end End Cap® synthesis have not showed any tendency to secondary displacement. (Table IX-X.)

$\mathrm{X}$-rays made in the 24th postoperative weeks showed anatomic reduction in all but one patient. This latter child showed good (12 degrees of dorsal angulation) reduction after one year, and anatomic reduction after 24 months.

\begin{tabular}{|l|r||r|}
\hline Complications & $\begin{array}{c}\text { Short double } \\
\text { elastic nailing } \\
(\mathrm{n}=84)\end{array}$ & $\begin{array}{c}\text { Short elastic nailing with End-Cap } \\
(\mathrm{n}=16)\end{array}$ \\
\hline Skin irritation & 9 & 1 \\
\hline Secondary displacement & 3 & 0 \\
\hline Superficial infection & 0 & 0 \\
\hline Deep infection & 0 & 1 \\
\hline Nerve or tendon damage & 0 & 0 \\
\hline
\end{tabular}

Table IX.

Numbers of different complications in the two types of short elastic nailing techniques 


\begin{tabular}{|c|c|c|c|c|c|c|}
\hline \multirow[t]{2}{*}{$\begin{array}{l}\text { Degree of axial } \\
\text { deviation }\end{array}$} & \multicolumn{3}{|c|}{$\begin{array}{l}\text { Short double elastic } \\
\text { nailing } \\
(n=84)\end{array}$} & \multicolumn{3}{|c|}{$\begin{array}{l}\text { Mono-elastic nailing with } \\
\text { end cap } \\
(N=16)\end{array}$} \\
\hline & $\begin{array}{l}\text { 1sth } \\
\text { week }\end{array}$ & $\begin{array}{c}\text { 4th } \\
\text { week }\end{array}$ & $\begin{array}{l}\text { 24th } \\
\text { week }\end{array}$ & $\begin{array}{l}\text { 1sth } \\
\text { week }\end{array}$ & $\begin{array}{c}\text { 4th } \\
\text { week }\end{array}$ & $\begin{array}{l}\text { 24th } \\
\text { week }\end{array}$ \\
\hline $\begin{array}{l}\text { Excellent } \\
\text { (maximum } 5 \text { degrees } \\
\text { of axial deviation) }\end{array}$ & 70 & 66 & 83 & 13 & 13 & 16 \\
\hline $\begin{array}{l}\text { Good } \\
\text { (maximum } 15 \text { degrees } \\
\text { of axial deviation) }\end{array}$ & 13 & 17 & 1 & 3 & 3 & 0 \\
\hline $\begin{array}{l}\text { Acceptable } \\
\text { (maximum } 30 \text { degrees } \\
\text { of axial deviation } \\
\text { within remodelling } \\
\text { range }\end{array}$ & 1 & 0 & 0 & 0 & 0 & 0 \\
\hline $\begin{array}{l}\text { Bad } \\
\text { (axial deviation is out } \\
\text { of remodelling range }\end{array}$ & 0 & 1 & 0 & 0 & 0 & 0 \\
\hline
\end{tabular}

Table X.

Degrees of axial deviations on X-rays after short elastic nailing of paediatric distal radial fractures at different checking times

\section{IV.5. Intraoperative sonography of radial elastic stable intramedullary nailing}

Ultrasonographic identification of EPL and Lister's tubercle in the transverse view was possible in all children. Determination of the position of the nail to EPL was also possible in all patients. Measured mean distance of the transverse view centre of the EPL and nail was $0.49 \mathrm{~cm}$ by US. (range: $0.3-0.62 \mathrm{~cm}, \mathrm{SD}=0.66$ ).Longitudinal view of $\mathrm{EPL}$ was not clearly defined in 2 cases.Based on the sonographic transverse view (insertion points were too close $(<0.3 \mathrm{~cm})$ to EPL) the operator decided repositioning the nails by 2 patients. On one occasion EPL movement was not seen with dynamic assessment, although the tendon 
was clearly identifiable. In this case, we decided re-bending the end of the nail. After correction, we were able to identify normal tendon movement. Sonographic procedures took average 5 minutes (range: $2-8 \mathrm{~min}$. mean $=4.8 \mathrm{~min}$ ) extra time during operations. We have not found EPL injury or septic complications postoperatively. All patients were followed for at least 12 months after operation. Nails were removed from all children without further complications.

\section{Discussion}

\section{V.1. Sonographic diagnosis of elbow fractures}

Most of the papers evaluating the utility of US in different elbow injuries concentrated on the presence of the sonographic FPS as a strong predictor of fractures. $(58,59,60,61,62)$

A positive radiological FPS develops when normal fat pad around the elbow is pathologically forced out from its resting place. (118)

Radiological FPS is a well-known phenomenon known for decades, many studies deal with its diagnostic value. $(119,120,121,122,123)$ While appearance of anterior FPS in lateral Xrays can be normal, posterior is generally considered pathological. (121)

Distinction of normal and pathological radiological FPS is not clearly defined. Its presence related to fractures is controversial. Sonographic FPS seems much more specific than radiologic and differs from it. (125) While lateral radiographs in elbow flexion has a positive fat pad sign with 5 to $10 \mathrm{ml}$ of fluid in the joint, sonography allows identification of 1 to $3 \mathrm{ml}$ posteriorly. (125) Nomenclature of abnormal FPS or lipohemarthros is not unified in the literature. (126) We considered sonographic FPS elevated if the dorsal border of the fat pad moderately exceeded (2 $-5 \mathrm{~mm})$ the level of the proximal humeral line in the dorsal longitudinal plane, and the border of the original fat pad and the fluid were clearly distinguishable. The diagnosis of LH was established if the border of the fat pad and intraarticular fluid were blurry, or the two seemed as an inhomogeneous, indistinguishable mass in the fossa and the elevation exceeded $5 \mathrm{~mm}$.

In our series we have not observed interrater disagreement in assessing the type of the different sonographic FPS. Distinction of LH and eFPS may have some importance for detecting a bony injury. We found LH to be more characteristic in supracondylar humeral 
and radial condylar fractures. The seven occult fractures with negative primary X-rays but positive sonography all showed LH.

We suppose that LH is rather a sign of occult fracture while post-traumatic elevated fat pad without any radiological abnormality can be the result of intraarticular fluid collection caused by a stronger impact. Several studies concluded that presence of radiological or sonographic FPS does not necessarily mean an occult fracture, but differentiation of LH and eFPS was not done. This however does not mean serious clinical importance because treatment and outcome of most paediatric occult elbow fractures and stronger joint contusions does not differ.

Unambiguously with other studies we think that the absence of abnormal FPS means the real importance which has a strong negative predictive value. $(119,120,121)$

In our series we found five children ( 1 radial condylar and two radial neck and two medial epicondylar fractures) with initially negative sonographic FPS.This can be since certain fractures do not cause immediate intraarticular bleeding or fluid collection. The elapsed time from the injury can also play a role in elevated fat pad or LH formation. Repeated US on the first week showed that FPS became positive in all fractures. At the same time cortical disruption and angulation were visible in the second (radial condylar fracture) or third (medial epicondylar fractures) sonographic planes so the presence of these fractures would not have been missed.

Utility of the II-V. longitudinal planes is due to the phenomena that ultrasonic waves are reflected totally by the bony cortex.

If the probe is parallel to the bone, the cortical side is represented as a sharp, straight line, and interruptions or angulations will be clearly visible. We have seen seven pseudo-positive cases when abnormality was present in the II and III planes. Out of these 6 were in the plane II and one in the plane III. No callus formation or other abnormality were confirmed at these children and complains disappeared at the latest in two weeks. Small disruptions were observed in the osteochondral line in these cases, which we think anatomic variations or small infractions without clinical consequences.

Radial condylar, proximal radial and proximal ulnar fractures all showed positivity in the corresponding planes thus these injuries can be detected even without the FPS.

Abnormality in the plane II-III. was less specific in medial epicondylar and supracondylar fractures, especially if these injuries are without displacement. X-rays of these fractures show very subtle findings. (Figure 13.) Several fractures with less clinical significance 
have not showed any cortical abnormality by US, but all showed FPS positivity so wold not have been missed. Elbow joint displacements without fractures also showed only LH positivity without another plane abnormality. In these cases, technically it was very difficult to visualise the standard planes, because of the altered joint relations. The degree of LH was enormous. Displaced fractures with operative indication all showed positive LH and at least one additional plane positivity.

In two young children ( 8 and 7 years old) we have found very subtle or no abnormalities in $\mathrm{X}$-rays, and US raised the suspect of a fracture requiring operative treatment. In these cases (a proximal radial and medial epicondylar fracture) most of the broken parts consisted of cartilaginous tissue which is invisible to conventional X-rays. We assume that in younger children US sometimes can give more accurate informations about the exact nature of the fracture than X-rays. In such cases, an MRI scan may determine the issue of the surgical indication. (Figure14,15.)

A longitudinal anterior sonographic plane could also be very useful but taking account the pain caused by the extension of the arm in the presence of a fracture we did not take it as a routine part of our protocol.

The four cortical sonographic planes without plane I. showed abnormality in $87 \%$ in all fractures. Evaluating the cortical views and the FPS together the specificity increased to 0, 99 and sensitivity to 1 , so using the five planes in a 90-degree bent position of the elbow seems to be enough.

Exact identification of the fracture types was possible in $68 \%$. These were minimally or not displaced radial condylar, type I supracondylar, proximal radial and ulnar fractures.

Summarising our result, we conclude that US is an effective tool in the screening of paediatric elbow fractures. Using additional longitudinal planes is more effective than the evaluation of the sonographic fat pad sign as a sole parameter. US may be enough as a definitive diagnostic tool in negative cases. US is a very useful imaging modality to detect occult fractures, and bony injuries without displacements, and in certain cases could be used instead of X-rays.

Identification of the presence of fracture displacement or dislocation is also possible by US but exact determination of the type of clinically serious injuries is not possible without X-rays. 

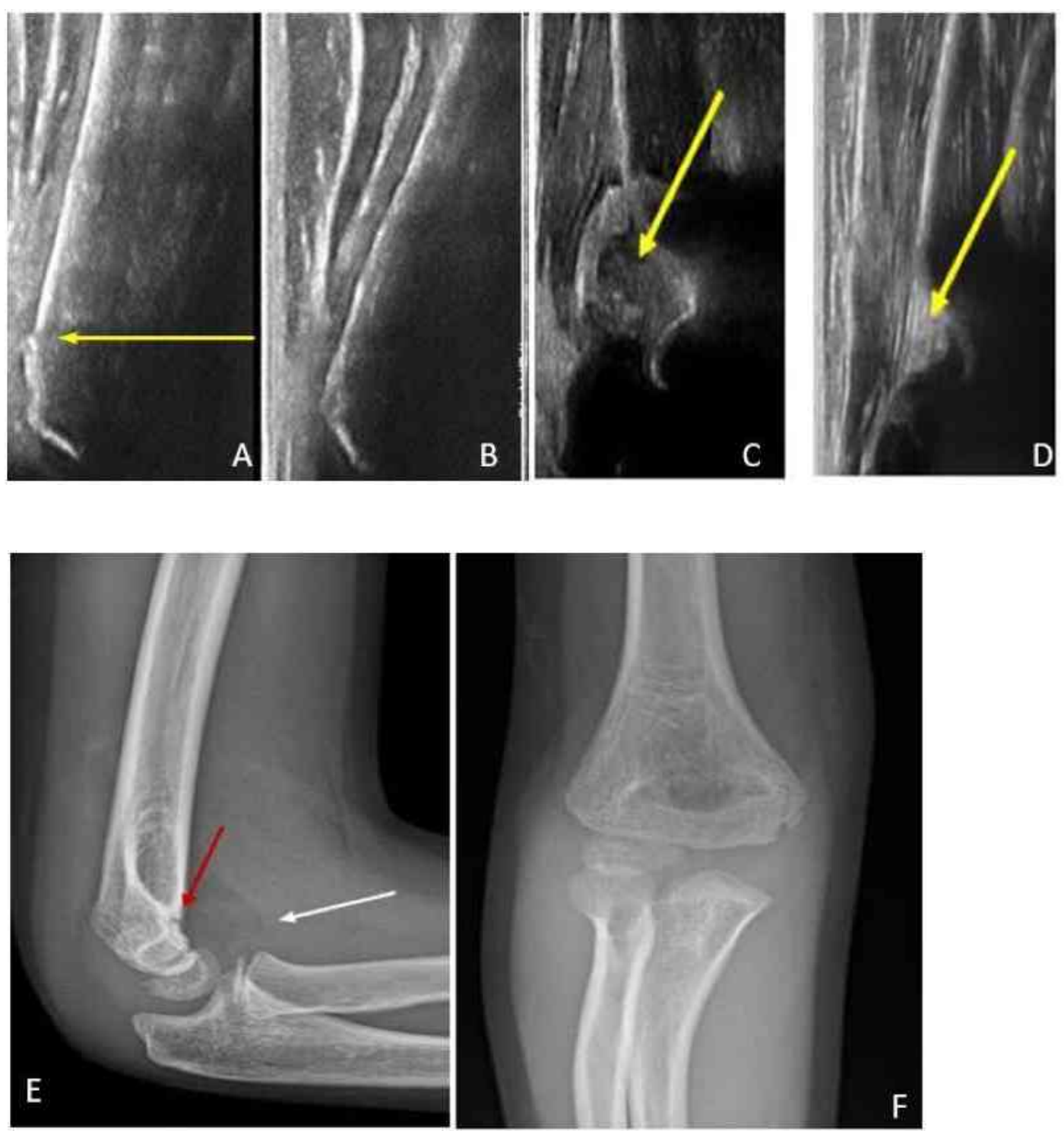

Figure 13. Supracondylar humeral fracture without displacement

A: Small cortical disruption can be seen in sonographic plane II (arrow) B: Cortical line does not show disruption in the contralateral healthy side. C: Lipohaemarthrosis in plane I. is a certain sign of a fracture. (arrow) D: Appearance of fat pad is normal in the contralateral healthy side. (arrow) E: lateral X-ray show radiological anterior fat pad sign (white arrow) and small cortical disruption in the ventral supracondylar area (red arrow). F: anteroposterior X-ray does not show any abnormality. 

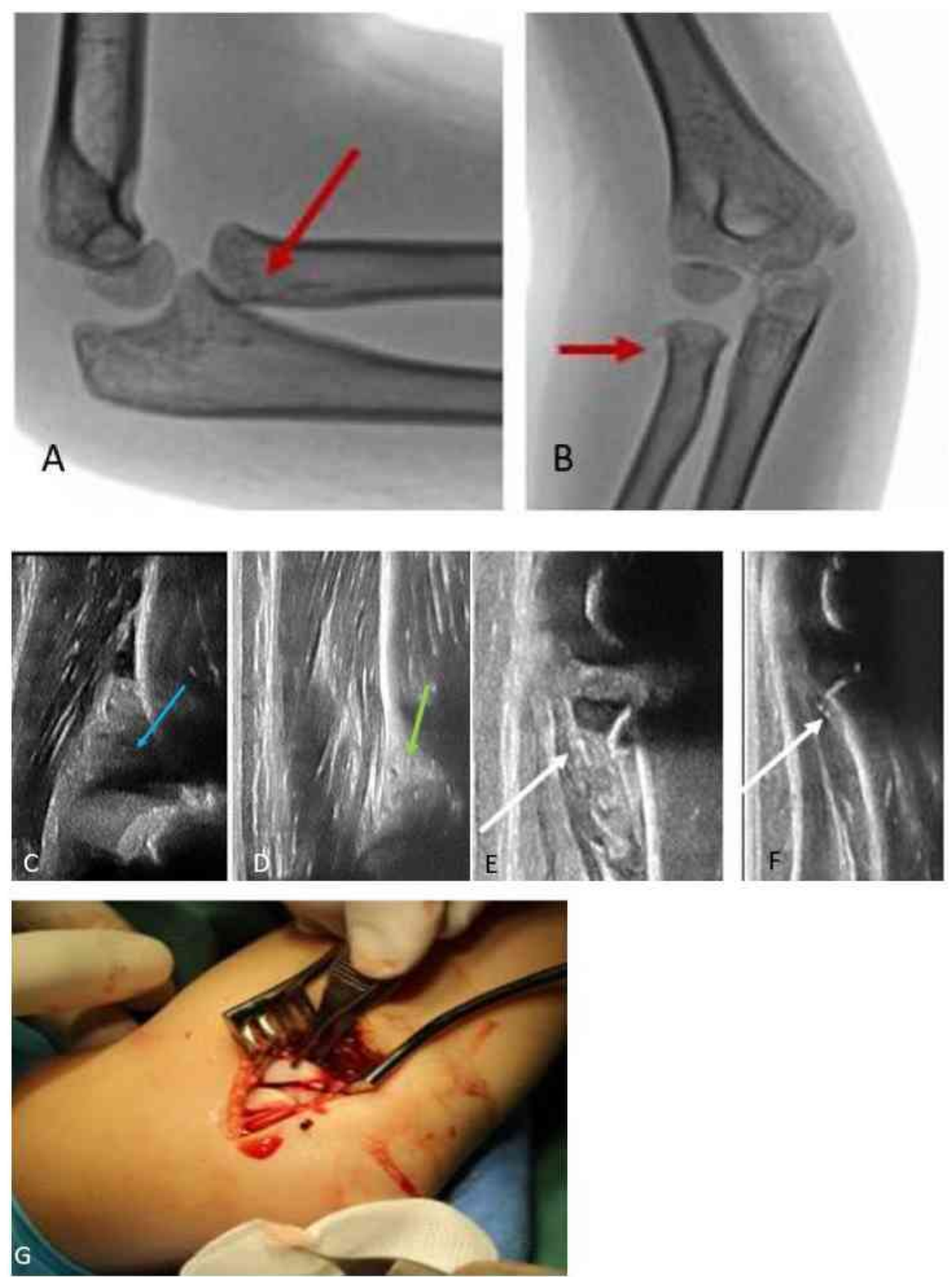

Figure 14. Intraarticular radial head fracture with subtle $\mathrm{X}$-ray findings

A-B: lateral and anteroposterior X-rays of an elbow of a 9 years old child. Most of the radial head consists of chondral tissue, severity of fracture cannot be judged by X-rays (red arrows). C: Extreme lipoheamarthrosis of the affected side raise the suspect of a displaced fracture (blue arrow). D: contralateral side, normal sonographic fat pad (green arrow) E: US shows angulation of the radial head. Only half of the chondral head is visible(arrow) F: contralateral healthy side, sonographic appearance of radial head is normal G: Intraoperative picture: there is a displaced intraarticular radial fracture, which needs synthesis 

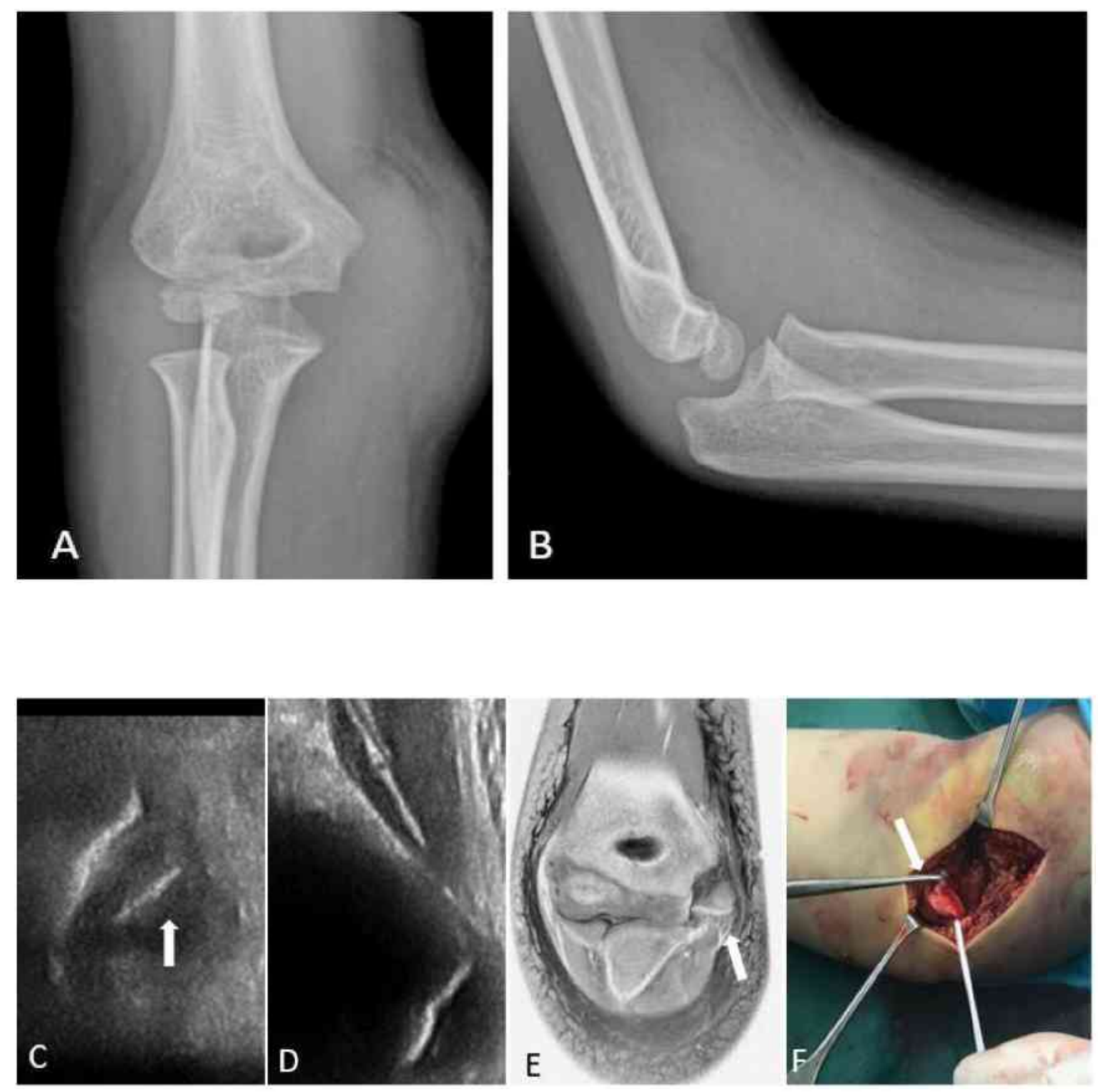

Figure 15. Displaced medial epicondylar fracture without X-ray abnormality

A-B: Anteroposterior and lateral X-rays of the elbow of an 8 years old child. There is a medial soft tissue swelling but no bony abnormality can be seen. $\mathbf{C}$ : sonographic view of the plane III, of the affected side - the hyperechogenic line indicates a dislocated medial epicondyle (arrow). D: unaffected side - there is no sign of avulsion. E: MRI scan of the elbow- arrow shows the avulsed epicondyle. F: intraoperative photo of the dislocated fragment 


\section{V.2. Sonographic diagnosis of pulled elbow}

Exact pathological basis of nursemaid elbow is not clearly defined. At last 13 theories of the pathophysiology were described. Based on the current available evidence PE means a soft tissue interposition in the radiocapitellar joint. (75) The older nomenclature, radial head subluxation" suggest a well definable pathoanatomical abnormality but imaging modalities have not confirmed the presence of any joint incongruence. $(76,77)$ Although several studies describe some special radiological sign which may relate to PE, these subtle changes have not proved useful in daily clinical practice. $(128,129,130)$ Several papers reported encouraging results of sonographic diagnosis of PE. Radiocapitellar distance differences, annular ligament integrity and entrapment, changes in the shape of supinator muscle and enlargement of the synovial fringe were described as potential signs of PE. (127) Although ultrasound is cheap, fast and radiation-free imaging modality, the specific sonographic signs of PE described by various authors are controversial. $(78,127,131)$

These methods aimed to confirm the diagnosis of PE and operators have not used dorsal sonographic planes to detect potential fractures. With our combined two-point sonographic planes we searched signs which confirm or rule out both PE and fractures. According to several studies the most reliable and reproducible sonographic sign of PE is the presence of synovial fringe enlargement. (SFE) This phenomenon is also called ,, hook" or ,J" sign and suggests a soft tissue interposition in the joint. $(78,79)$ Success of the reduction can be checked by its disappearance. Although certain authors found a $100 \%$ sensitivity and specificity for PE of this finding, others reported less excellent results. In our series we found only $76 \%$ positivity of SFE at our PE cases. $(25,78,127)$ It was a further problem that evaluation of the ventral plane was more dependent on the operators, interrater agreement showed less accuracy in this view. This can be due the fact, that US examination is less feasible in the ventral position, when the transducer should be held in a longitudinal position over the radiocapitellar joint while the child's elbow is extended and motionless. Normal parameters of the synovial fringe are not clearly defined, so enlargement can be evaluated by comparing the opposite elbow. (25) We found that a marked synovial fringe sometimes also can be seen in the healthy arm in children with generalized hyperlaxity, so determination of positivity is not possible in these cases. In spite of these we found SFE detection very useful, because the diagnosis of PE was made clear in more than two-thirds 
of cases, and fractures never showed this change. Dorsal sonographic view improved this diagnostic accuracy.

Dorsal sonographic view proved easier to produce, and interrater agreement of evaluation the presence or absence of EFPS have been excellent in all cases. PE usually does not show fat pad abnormality which is a sign of intraarticular fluid accumulation caused rather by fractures or forceful contusions. Sonographic fat pad sign is more sensitive than radiological, even 1-3ml intraarticular fluid accumulation can cause an elevation of the posterior border of the pad in the olecranon fossa. The connection between sonographic eFPS and elbow fractures is confirmed by many studies. $(25,26)$. Although we found one study in the literature which reported sonographic elevated fat pad sign or lipohaemarthros in 8 radial head subluxations out of 42 children in our series we experienced these phenomena only in one case out of the 196 PE. (131) That child had an unreduced PE which was older than 24 hours and showed SFE positivity. The other 195 children with confirmed PE all showed normal FPS whereas the other 9 cases with eFPS or lipohaemarthros all proved to have supracondylar humerus fractures and no SFE positivity. We consider it possible that PE which is unreduced more than 6-8 hours may cause intraarticular fluid accumulation and elevated FPS. The average time between injury and definitive treatment in our hospital were 2-6 hours, and only 17 children had longer anamnesis than 12 hours. This is a potential weakness of our study because older, unreduced injuries may show other results. We would like to note if even a certain portion of older PE injuries show positive FPS without SFE positivity that would only slightly increase the clinical suspect of fractures and a few unnecessary pre-reduction radiographs.Based only by the physical findings we found 9 cases $(4.39 \%$ ) which were thought to be PE by our examiners and proved to be fractures by imaging modalities. We think that a lesser problem than a tardy indication of X-rays in the case of a true fracture after a few unsuccessful and painful reduction attempts.

\section{V.3. Sonographic diagnosis of distal forearm fractures}

The diagnosis of paediatric distal forearm fractures is traditionally based on standard twoplane X-rays. (132) The presence of a fracture or epiphyseolysis, the type of injury, axial deviation or shortening are the main elements which should be determined by X-rays. The 
information obtained from the X-rays is usually sufficient to set up an immediate therapeutic plan. (132)

Ultrasonic diagnostics of distal forearm fractures is made possible by the characteristic injuries affecting this area. Children with open growth plates and under the age of fourteen rarely have irregular and displaced intraarticular fractures. (133) Paediatric distal metaphyseal or epiphyseal injuries show typical patterns, which can be visualisable by the sonographic mapping of the bony cortex. (86)

The six standard planes used in our clinical practice proved to be enough to determine the presence or the type of a fracture. In our study X-rays were considered as the golden standard method of diagnostics. We observed seven pseudo-positive and seven pseudonegative sonographic results. All these results were in the first group, which needed no therapeutic interventions and no further complications were expected. The pseudo-negative cases were observed in the initial part of the study, so we suppose this error were due to the "learning curve" period.

Out of the seven children who were considered as pseudo-positive four had prolonged pain in the area if the wrist. Although the reference X-rays were negative, the presence of a cortical crease of the affected side was clear in US, when we compared it with the healthy side. We have seen these phenomena also at several ulnar fractures when only the injury of the radius was clearly visible in X-rays. (Figure 16.) We suppose that these were occult fractures and US proved to be more sensitive in their detection. An MRI scan could have confirmed our assumption objectively, but it was not performed due to the lack of clinical consequences.

In the group two we classified injuries which needed reduction and plaster cast immobilisation but no operative interventions. These were mostly angulated greenstick fractures or epiphyseolysis with displacements. We have not observed difference between the diagnostic efficiency of US and X-rays. Using only US, we were even able to determine the exact configuration and degree of angulation of these stable fractures. Based on these findings even the reduction manoeuvre and its checking could be performed by US. Several study with small number of cases confirm this hypothesis. So far, it has not spread at all as an accepted practice. $(87,88,89)$ (Figure 17.)

The exact evaluation of unstable fractures with shortening and severe displacement was more difficult. Although there were no pseudo-negative cases in this group, the determination of exact fracture pattern was not possible only by US. These children are 
usually candidates for an intervention, and X-rays are essential for preoperative planning. In these cases, sonography is useful only as a screening modality to confirm the presence of a fracture which needs operative intervention.
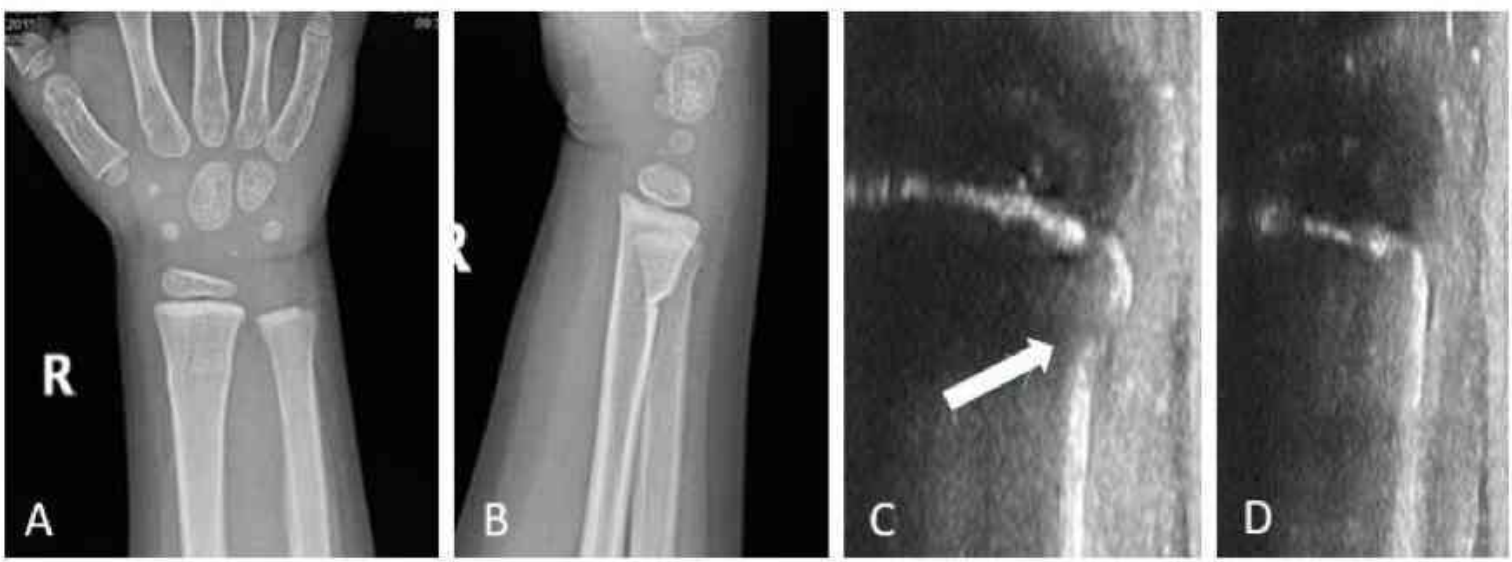

Figure 16. Ultrasound and X-ray pictures of distal forearm torus fracture

A-B: Anteroposterior and lateral radiographs show a distal radial torus fracture. Ulnar fracture is not evident $\mathbf{C}$ : Sonography shows a clear cortical crease in dorsal ulnar plane (arrow)D: healthy side, no cortical crease

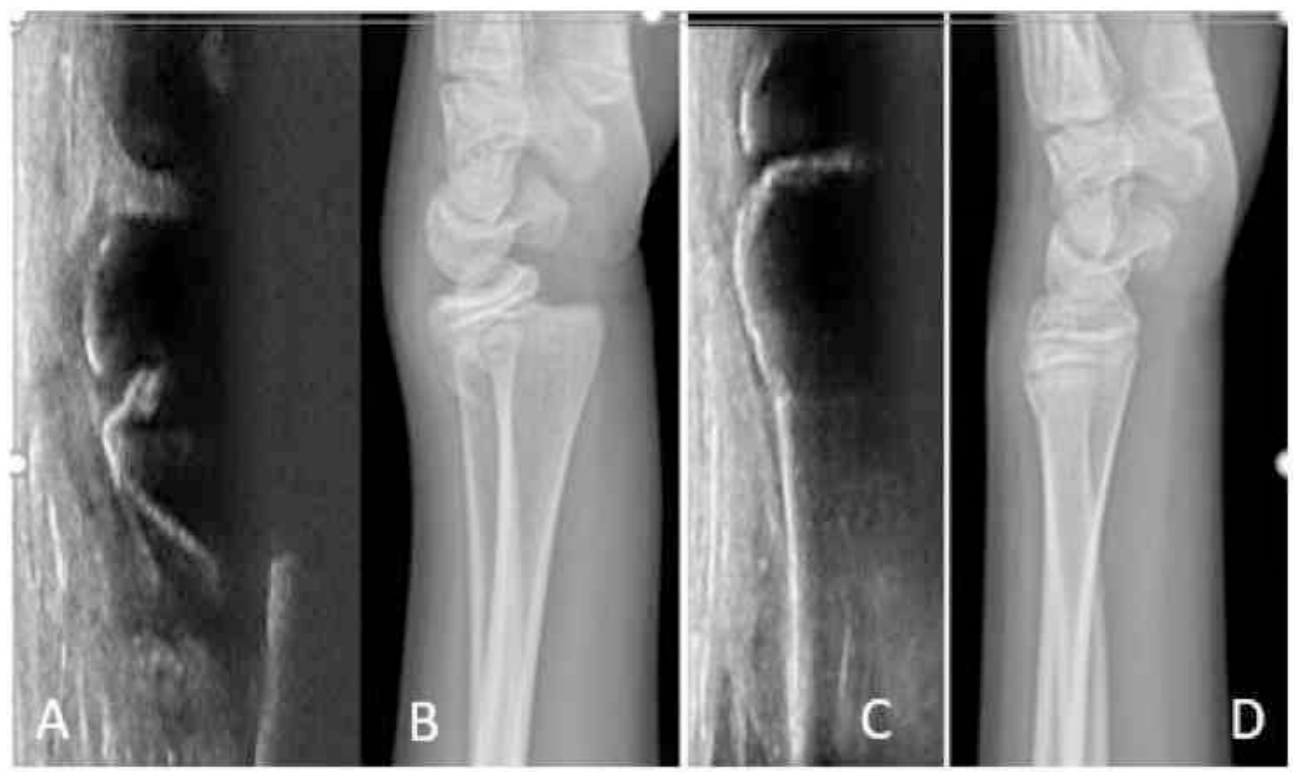

Figure 17. Checking of reduction of a Salter-Harris type II. fracture by X-rays and sonography

A: Dorsal radial (DR)sonographic plane of Salter-Harris type II. epiphyseolysis B: lateral X-ray of Salter-Harris type II. epiphyseolysis C: DR sonographic plane of the radius after reduction D: lateral X-ray of the radius after reduction 
A special problem may be the case of a pathological fracture. Although we have not found such patient in our study, we suppose that the sonographic sign of the inflated or eroded bony cortex would draw attention to the need of other imaging modalities. As a summary, we conclude that most of the paediatric distal forearm fractures could be diagnosed only by US. Negative cases also can be ruled out by sonography. X-rays should only be used for unstable, severely displaced fractures which need operative intervention.

\section{V.4. Short elastic intra-medullary nailing of distal forearm fractures}

The short double nailing technique is a modification of the classic ESIN method. The biomechanical principles are the same as for long diaphysial fractures, which is the concept of symmotrical splinting by 2 elastic nails, each supporting the inner cortex. $(113,114,135,136)$ The main difference is the length and the pre-contoured curve of the nails. Ideally, the highest points of convexity of titanium elastic nails are at the level of the fracture symmetrically opposite to each other. (114) Using long nails, the highest point of the curvature shifts toward the central region of the diaphysis, so in the cases of metaphyseal or diametaphyseal fracture, it would be very eccentric from the fracture line. Using short "c"-shaped and "mini" nails, the maximal curve is at the level of the fracture and the tension within the nail provides an optimal stabilising effect. The 2 nails ensure a long contact area with the inner cortex, which is mandatory for axial stability. Using 2 nails from different entry points, but from the same level, provides rotational, translational, and bending/bowing stability. We hypothesise that "short" ESIN nails inserted at the distal metaphyseal area work the same way as conventional ESIN in a shaft fracture. In an animal study, Johnson et al have shown that at $3 \mathrm{~mm}$ diameters or more beyond the fracture site, the length of the nail does not significantly affect the biomechanical properties of the construct. (134) The first nail is usually thicker $(2.5-3 \mathrm{~mm}$ diameter) then the implants which are used in conventional forearm ESIN techniques. $(2-2.5 \mathrm{~mm})$ This is necessary because short nails have the greatest tensing effect in the broad diametaphyseal zone of the radius. The main role of the second nail is to increase rotational stability. We usually choose a thinner nail for the second one (2-2.5 mm diameter) to minimise the chance of a potential iatrogenic fracture. We have not experienced differences in rotational stability using a 
thinner second nail, but insertion was easier. If we choose a thinner first nail (1.5-2 mm), flexion-extension stability significantly decreases. Stability was tested under intraoperative fluoroscopy in maximally dorsal-extended and palmar-flexed position of the hand. We achieved the best stability with $2.5-3$ and $2-2.5 \mathrm{~mm}$ diameter nail combinations. The insertion points (Lister tubercle and radial dorsal side of the radius) are the well-known insertion places of conventional radial ESIN nails. Both areas are located proximally to the physeal plate thus an iatrogenic growth plate injury can be prevented. $(113,114)$ It is very important to visualise both the dorsal and the radial entry points adequately to avoid iatrogenic injury to the long extensor pollicis tendon and the superficial radial nerve. Incorrect insertion points or malposition of the entry holes can jeopardise the physeal plates, the sensory branch of the radial nerve, or the tendons. $(113,114)$ The insertion of a second nail becomes obsolete in the mono-elastic nailing technique because rotatory stability is given by the End Cap $\left.{ }^{\circledR}\right)$ implant. End Cap ${ }^{\circledR}$ also protects soft tissues. Fixation with one nail reduces the risk of the two insertion points but needs a wider incision, because tendons should be carefully protracted due to the size of the End Cap ${ }^{\circledR}$ implant.

Using double elastic nailing, we have observed only mild complications like skin irritation which was caused by the end of the dorsally inserted and relatively too long nail under the skin. We hypothesise that this problem can be attributed to improper cutoff of nails during the learning curve period of the technique. When nails are cut in a maximally palmar-flexed position of the wrist just below the level of the skin, this irritation problem ceases. The use of End Cap $\mathbb{R}$ implant also eliminated this problem.

Anatomical reduction is not an absolute requirement treating these kinds of fractures due to the remodelling capacity of the distal radius. Although we always strive to achieve an accurate anatomical reduction this is not always possible with closed techniques in the case of oblique fractures. We observed several moderate secondary dislocations in the first postoperative week, but they were in the remodelling range. Further secondary displacement was not observed. One child had a greater secondary dislocation which exceeded the expected remodelling capacity, but he also regained full function to the $24^{\text {th }}$ postoperative week and anatomic reduction after two years. In this case radiological remodellation took a longer time but did not affect functional recovery. Fractures which were stabilised with one nail and soft tissue protectors have not shown tendency for secondary dislocation. By the end of the follow-up, all X-rays showed anatomical reduction. We have not observed any growth disturbances. 
None of the children needed a long rigid cast postoperatively. In our practice we applicate a short rigid splint immediately after operation which was changed to a removable brace in the second postoperative day. The brace was removed when the child dared to start using his hand without pain. Fifteen smaller children (under the age of 7) needed brace treatment for four weeks. In their cases the reason for longer brace treatment was rather the uncertainty of cooperation.

For the time being it is not possible drawing any conclusions about the superiority of the two versions of short elastic intramedullary nailing and percutaneous pinning due to the lack of randomised studies. We think that the greatest advantages of our techniques are the early mobilisation with a short splint, the elimination of potential growth plate injuries and pin-related complications. Further prospective and biomechanical studies are required to verify our initial good experiences.

\section{IV.5. Intra-operative sonography of radial elastic stable intramedullary nailing}

Among the muscles involved in thumb movement, the extensor pollicis longus (EPL) tendon of the hand is considered the most consistent structure with the least variation among individuals. (137) Lister's tubercle is a prominent and easily visible landmark in the dorsal side of the radius by US. (138) The exact ethology of paediatric EPL injury in forearm fractures is still a question of debate. In adult populations direct injury, increased pressure in the third extensor compartment, poor vascularisation, chronic mechanical irritation caused by an implant, callus formation or spontaneous idiopathic rupture may be considered as pathogenic factor theoretically. $(139,140,141,142)$ Most of the paediatric EPL injuries found in the literature are related to dorsal entry elastic nailing, it seems to be a unique complication of this approach. $(143,144,145,146,147,148)$ A small cohort study identified no significant patient characteristics as any predictor of EPL rupture. (145) In a study of 9 paediatric ruptures the nail entry site was directly related to the location of EPL. (149) Direct injury of the tendon during insertion, or chronic irritation caused by the end of the nail can lead to tendon rupture. (148) In a six years period in our institution (between 2010 and 2016) we have performed 354 dorsal entry radial nailing procedures and found 7 EPL injuries retrospectively. Four cases were identified as acute (<one week after surgery) 3 as chronic ( $>$ one week postoperatively) injury. During reoperation, we found 6 complete 
ruptures. In all chronic and in one acute case extensor indicis tendon transfer has been performed. Direct repair was possible in 2 acute cases.

In one case rupture of the EPL tendon was not confirmed intraoperatively: the tendon was mechanically obstructed by the nail, and this caused the block of motion. The reposition of the implant has solved the problem. We hypothesise that a late rupture would have occurred without our early intervention. Cutting and bending the nail under the skin and above the level of the tendon helps to reduce the risk of skin irritation. (150)

Reviewing the literature and our experiences we concluded that optimisation of the insertion points and the position of the extraosseal end of the nails can reduce the risk of both acute and chronic ruptures. Intraoperative ultrasound has been proven an easy and useful tool for visualising these optimal reference points. We found that exact sonographic differentiation of Lister's eminence and transverse view of EPL were easily feasible. The visualisation of the end of the nail, and the determination of its position to Lister's eminence and tendon during insertion is more difficult and technically demanding. Despite this latter fact using sonographic guidance took an average extra 5 minutes during operations. Two times the longitudinal views of tendons were not clearly identifiable. We think this was rather a technical problem in the early learning curve period.

We think that with the increasing application of musculoskeletal ultrasound intraoperative use will also become more common. With appropriate training, an application of IOP-US can be a valuable addition of image intensifier and can become part of the daily surgical routine. 


\section{Conclusions}

US is an effective diagnostic modality in the screening of distal paediatric forearm fractures.

US shows the same diagnostic efficacy as X-rays in the exact identification of fractures without displacements and angulated greenstick fractures.

Occult radius torus fractures in children may be detected more accurately by US.

US can detect unstable and severely displaced distal forearm fractures, but X-rays are mandatory for exact fracture identification and therapeutic plan.

Paediatric elbow fractures can be screened by point of care ultrasound

Using five standardised US planes increases the diagnostic efficacy of paediatric elbow fractures.

Occult paediatric elbow fractures can be detected by US

In younger children US may give more accurate information about the exact nature of the fracture than X-rays.

The differential diagnosis of pulled elbow can be safely confirmed by a standardised twoplanes US method.

Short intramedullary elastic nailing may be an alternative to percutaneous pinning in the treatment of severely displaced paediatric distal metaphyseal fractures.

Using short intramedullary nailing in distal paediatric forearm fractures there is a need only a short cast for one or two weeks postoperatively.

Intraoperative sonography may reduce the risk of extensor pollicis longus tendon injury during dorsal entry elastic intramedullary nailing of the distal radius.

The diagnostic and therapeutic options presented in my dissertation seem very promising in the treatment of paediatric forearm and elbow fractures.

However, it is important to note that our conclusions must be scientifically further strengthened. High level evidences are unavailable in the literature that would clearly demonstrate the effectiveness of ultrasonic fracture diagnostics. There are currently no comparative studies to demonstrate the advantages of short elastic nailing to other techniques. Ultrasound assisted musculoskeletal operations mean new perspective, which utility are confirmed only by a few papers currently. Increasing the evidence of the methods presented in the dissertation to a higher level and creating a legal background is the challenge of the future. 


\section{Acknowledgments}

This work was created with the help of many contributors. I would like to thank the following people.

My mentor, Dr. Sándor Pintér gave me a helping hand, encouragement and constructive criticism.

My colleagues, dr. Nikoletta Gáti, dr. Erika Kalóz, dr. Szilvia Papp, dr. Zsuzsa Bíró, dr. Luca Tóth, have not regret their time to help with the methods presented in my dissertation.

I would like to express my thanks to the nurses and physiotherapists of our paediatric department.

Special thanks to Dr. Tamás Kassai who invited me to the world of paediatric trauma surgery.

Special thanks to Dr. Zsófia Farbaky for the inspiration and the many teachings about musculoskeletal ultrasound.

Without my little family I wouldn't have done anything.

My love, Gyöngyi gave me the starter boost.

My son, Nimród taught me much more than anyone else.

There are four members of my family who are no longer with me. My grandfather showed an example, my mother gave me strength, my grandmother raised me up. My father showed me a way, but I just wander in his footsteps.

I miss you much.

I recommend this work for your memory. 


\section{References}

1.Townsend, DJ; Bassett, GS. (1996) Common elbow fractures in children. Am Fam Physician. vol. 53(6): pp. 2031-41

2. Naranje, SM; Erali, RA; Warner, WC; Sawyer, JR; Kelly, DM (2016) Epidemiology of Pediatric Fractures Presenting to Emergency Departments in the United States J Pediatr Orthop, vol. 36(4): pp. e45-8

3.Shah, NS; Buzas, D; Zinberg, EM (2015) Epidemiologic dynamics contributing to pediatric wrist fractures in the United States. Hand (NY); 10: 266-271.

4. Voth, M; Lustenberger, T; Auner, B; Frank, J; Marzi, I (2017) What injuries should we expect in the emergency room? Injury. Oct;48(10):2119-2124.

5.Camp, MW; Barnes, JR; Damany, M; Donnan, LT (2018) Impact of web-based clinical practice guidelines on paediatric fracture clinics ANZ J Surg, vol. 88(3) pp. 232-235

6. Shrader, MW; Campbell, MD; Jacofsky, DJ (2008) Accuracy of emergency room physicians' interpretation of elbow fractures in children Orthopedics, vol. 31(12)

7. Minnes, BG; Sutcliffe, T; Klassen, TP (1995) Agreement in the interpretation of extremity radiographs of injured children and adolescents Acad Emerg Med, vol. 2(9) pp. 826-30

8. Supakul, N; Hicks, RA; Caltoum, CB; Karmazyn, B (2015) Distal humeral epiphyseal separation in young children: an often-missed fracture-radiographic signs and ultrasound confirmatory diagnosis AJR Am J Roentgenol, vol. 204(2) pp. W192-8

9. Simanovsky, N; Lamdan, R; Hiller, N; Simanovsky, N (2009) Sonographic detection of radiographically occult fractures in pediatric ankle and wrist injuries J Pediatr Orthop, vol. 29(2) pp. $142-5$ 
10. Bae, DS; Howard, AW (2012) Distal radius fractures: what is the evidence? J Pediatr Orthop, vol. 32 Suppl 2 pp. S128-30

11.Joshi, N; Lira, A; Mehta N; Paladino, L; Sinert, R (2013) Diagnostic accuracy of history, physical examination, and bedside ultrasound for dagnosis of extremity fractures in the emergency department: a systematic review Academic Emergency Medicine Vol. 20, No. 1

12. Varga, M; Józsa, G; Fadgyas, B; Kassai, T; Renner, A (2017) Short, double elastic nailing of severely displaced distal pediatric radial fractures: A new method for stable fixation Medicine (Baltimore), vol. 96(14) pp. e6532

13. Varga, M; Gáti, N; Kassai, T; Papp, S; Pintér, S (2018) Intraoperative sonography may reduce the risk of extensor pollicis longus tendon injury during dorsal entry elastic intramedullary nailing of the radius in children Medicine (Baltimore), vol. 97(24) pp. e11167

14. Bonasso, PC; Dassinger, MS; Wyrick, DL; Gurien, LA; Burford, JM; Smith, SD (2018) Review of bedside surgeon-performed ultrasound in pediatric patients J. Pediatr. Surg.,

15. Gleeson, T; Blehar, D Point-of-Care Ultrasound in Trauma (2018) Semin. Ultrasound CT MR, vol. 39(4) pp. 374-383

16. Bastos, MG; Novaes, AKB; Pazeli, JMP Traditional and ultrasound physical examinations: a hybrid approach to improve clinical care (2018) Rev Assoc Med Bras vol. 64(5) pp. $474-480$

17. Kuo-Chih Chen, Aming Chor-Ming LinChee-Fah Chong, Tzong-Luen Wang (2016) An overview of point-of-care ultrasound for soft tissue and musculoskeletal applications in the emergency department Journal of Intensive Care 4:55 
18. Siciliano, R Radiological Examinations in Pediatric Age (2017) Ann Ig, vol. 29(2) pp. $134-140$

19. Leung, RS (2015) Radiation Protection of the Child from Diagnostic Imaging Curr Pediatr Rev, vol. 11(4) pp. 235-42

20. Strauss, KJ; Kaste, SC (2006) ALARA in pediatric interventional and fluoroscopic imaging: striving to keep radiation doses as low as possible during fluoroscopy of pediatric patients--a white paper executive summary J Am Coll Radiol, vol. 3(9) pp. 686-8

21. Barbuto, L; Di Serafino, M; Della Vecchia, N; Rea, G; Esposito, F; Vezzali, N; Ferro, F; Caprio, MG; Vola, EA; Romeo, V; Vallone, G Pediatric musculoskeletal ultrasound: a pictorial essay (2018) J Ultrasound

22. Vanderhave, KL; Brighton, B; Casey, V; Montijo, H; Scannell, B (2014) Applications of musculoskeletal ultrasonography in pediatric patients J Am Acad Orthop Surg, vol. 22(11) pp. 691-8

23. Czyrny, Z (2017) Standards for musculoskeletal ultrasound J Ultrason, vol. 17(70) pp. $182-187$

24. Hedelin, H; Tingström, C; Hebelka, H; Karlsson, J (2017) Minimal training sufficient to diagnose pediatric wrist fractures with ultrasound Crit Ultrasound J, vol. 9(1) pp. 11

25. Minagawa, H; Wong, K. (2014) Musculoskeletal ultrasound, echo anatomy and scan technique, Ohmsha,

26. Pai, DR; Thapa, M (2013) Musculoskeletal ultrasound of the upper extremity in children Pediatr Radiol, vol. 43 Suppl 1 pp. S48-54

27.Leitglieb, N (1986) A new noninvasive quantitative method for fracture diagnosis.

Medical progress through technology. 11, pp 185-190 
28. Leitgeb N, Bodenteich A, Schweighofer F, Fellinger M. (1990) Ultrasonic diagnosis of fractures. Ultraschall Med 1990; 11:206-9.

29. Farbaky, Zs (2004) A mozgásszervi ultrahang vizsgálat alapjai Tordas és társa kft,

30.Tuijthof, GJ; Kok, AC; Terra, MP; Aaftink, JF; Streekstra, GJ; van Dijk, CN; Kerkhoffs, GM (2013) Sensitivity and specificity of ultrasound in detecting (osteo)chondral defects: a cadaveric study Ultrasound Med Biol, vol. 39(8) pp. 1368-75

31.Ramirez-Schrempp, D; Vinci, RJ; Liteplo, AS (2011) Bedside ultrasound in the diagnosis of skull fractures in the pediatric emergency department Pediatr Emerg Care, vol. 27(4) pp. $312-314$

32.Hübner, U; Schlicht, W; Outzen, S; Barthel, M; Halsband, H (2000) Ultrasound in the diagnosis of fractures in children JBJS. 82-B, No. 8,

33. Varga, M; Tóth, L; Ribes, K; Pintér, S;(2019) Ujjtörések vizsgálata ultrahanggal gyermekkorban Magyar Traumatológia, kézsebészet, plasztikai sebészet (Under publication)

34. Yousefifard, M; Baikpour, M; Ghelichkhani, P; Asady, H; Darafarin, A; Esfahani, A; Hosseini, M; Yaseri, M; Safari, S (2016) Comparison of Ultrasonography and Radiography in Detection of Thoracic Bone Fractures; a Systematic Review and Meta-Analysis Emerg (Tehran), vol. 4(2) pp. 55-64

35. Cross K, P; Warkentine F, H; Kim I, K; Gracely M; Paul I, R (2010)

Bedside ultrasound diagnosis of clavicle fractures in the pediatric emergency department Academic Emergency Medicine 17 (7), 687-693,

36.Simanovsky N., Lamdan R., Hiller, N, (2009) Sonographic Detection of Radiographically Occult Fractures in Pediatric Ankle and Wrist Injuries Pediatr Orthop \& Volume 29, Number 2, March 
37. Fukushima, Y; Ray, J; Kraus, E; Syrop, IP; Fredericson, M A Review (2018)

Proposed rationale for the use of ultrasonography as a diagnostic modality in the identification of bone stress injuries J Ultrasound Med, vol. 37(10) pp. 2297-2307

38.Tessaro, MO; McGovern, TR; Dickman, E; Haines, LE (2015) Point-of-care ultrasound detection of acute scaphoid fracture Pediatr Emerg Care, vol. 31(3) pp. 222-4

39. Alexander, JE; Seibert, JJ; Glasier, CM; Williamson, SL; Aronson, J; McCarthy, R; Rodgers, AB; Corbitt, SL (1989) High-resolution hip ultrasound in the limping child J Clin Ultrasound, vol. 17(1) pp. 19-24

40. Palaniappan, M; Indiran, V; Maduraimuthu, P (2017) Ultrasonographic Diagnosis of Slipped Capital Femoral Epiphysis Pol J Radiol, vol. 82 pp. 149-151

41. Bozorgia F, Azarb MS, Montazera SH, Heidaria SF, and Khalilianc A (2017) Accuracy of Ultrasound for Diagnosis of Femur Bone Fractures in Traumatic Patients Journal of Clinical \& Experimental Orthopaedics Vol.3 No.1:27

42. Hile, DC; Morgan, AR; Laselle, BT; Bothwell, JD (2012) Is point-of-care ultrasound accurate and useful in the hands of military medical technicians? A review of the literature Mil Med, vol. 177(8) pp. 983-7

43. Schmid, GL; Lippmann, S; Unverzagt, S; Hofmann, C; Deutsch, T; Frese, T (2017) The Investigation of Suspected Fracture-a Comparison of Ultrasound with Conventional Imaging Dtsch Arztebl Int, vol. 114(45) pp. 757-764

44. Ackerman, O; Eckert, K; (2015) Bone fracture ultrasound EFSUMB Course Book Editor: Dietrich, CF

45. Sconfienza, LM; Albano, D; Allen, G; Bazzocchi, A; Bignotti, B; Chianca, V; Facal de Castro, F; Drakonaki, EE; Gallardo, E; Gielen, J; Klauser, AS; Martinoli, C; Mauri, G; McNally, E; Messina, C; Mirón Mombiela, R; Orlandi, D; Plagou, A; Posadzy, M; de la Puente, R; Reijnierse, M; Rossi, F; Rutkauskas, S; Snoj, Z; Vucetic, J; Wilson, D; 
Tagliafico, AS (2018) Clinical indications for musculoskeletal ultrasound updated in 2017 by European Society of Musculoskeletal Radiology (ESSR) consensus Eur Radiol,

46.Blankstein, A (2011) Ultrasound in the diagnosis of clinical orthopedics: The orthopedic stethoscope World J Orthop February 18; 2(2): 13-24

47.Lee, JE; Kim, JB; Choi, ES (2017) Ultrasonography-guided reduction of pediatric radial neck fractures BMC Musculoskelet Disord, vol. 18(1) pp. 516

48.Soldado, F; Knorr, J; Haddad, S; Diaz-Gallardo, P; Palau-Gonzalez, J; Mascarenhas, VV; Karmali, S; de Gauzy, JS (2015) Ultrasound-guided Percutaneous Medial Pinning of Pediatric Supracondylar Humeral Fractures to avoid Ulnar Nerve Injury Arch Bone Jt Surg, vol. 3(3) pp. 169-72

49.Balfour, GW (2016) Using Ultrasound to Prevent Screw Penetration J Hand Surg Am, vol. 41(3) pp. 453-6

50.Gurbuz, Y; Kucuk, L; Gunay, H; Ozaksar, K; Sugun, TS; Bilge, O (2017)

Comparison of ultrasound and dorsal horizon radiographic view for the detection of dorsal screw penetration Acta Orthop Traumatol Turc, vol. 51(6) pp. 448-450

51.Pattamapaspong, N; Kritsaneephaiboon, A (2017) Effectiveness of sonography assisted minimal invasive plate osteosynthesis (MIPO) compare with fluoroscope assisted in femoral shaft fracture: A cadaveric study Injury, vol. 48(8) pp. 1758-1763

52. Zhe, Z; Jianjin, Z; Fei, S; Dawei, H; Jiuzheng, D; Fang, C; Yongwei, P (2018) Intraoperative ultrasound-guided reduction of femoral shaft fractures using intramedullary nailing: a technical note Arch Orthop Trauma Surg,

53.Petrover, D; Hakime, A; Silvera, J; Richette, P; Nizard, R (2018) Ultrasound-Guided Surgery for Carpal Tunnel Syndrome: A New Interventional Procedure Semin Intervent Radiol, vol. 35(4) pp. 248-254 
54. DeFroda, SF; Hansen, H; Gil, JA; Hawari, AH; Cruz, AI (2017) Radiographic Evaluation of Common Pediatric Elbow Injuries Orthop Rev (Pavia), vol. 9(1) pp. 7030

55.Beckmann, NM; Crawford, L (2017) Salter-Harris I fracture of the distal humerus in a neonate: imaging appearance of radiographs, ultrasound, and arthrography Radiol Case Rep, vol. 12(3) pp. 571-576

56.Courvoisier, A; Calvelli, N; Bourgeois, E; Eid, A; Griffet, J (2016) Pitfalls in the diagnosis of occult elbow fractures in children Arch Pediatr, vol. 23(8) pp. 869-74

57. Zhang, JD; Chen, H (2008) Ultrasonography for non-displaced and mini-displaced humeral lateral condyle fractures in children Chin. J. Traumatol., vol. 11(5) pp. 297-300

58. Davidson RS, Markowitz RI, Dormans J, Drummond DS (1994) Ultrasonographic evaluation of the elbow in infants and young children after suspected trauma J Bone Joint Surg Am, vol. 76(12) pp. 1804-13

59.Cho, KH; Lee, SM; Lee, YH; Suh, KJ (2010) Ultrasound diagnosis of either an occult or missed fracture of an extremity in pediatric-aged children Korean J Radiol, vol. 11(1) pp. 84-94

60.Eckert, K; Ackermann, O; Janssen, N; Schweiger, B; Radeloff, E; Liedgens, P (2014) Accuracy of the sonographic fat pad sign for primary screening of pediatric elbow fractures: a preliminary study J Med Ultrason vol. 41(4) pp. 473-80

61.Eckert, K; Ackermann, O; Schweiger, B; Radeloff, E; Liedgens, P (2013) Ultrasound evaluation of elbow fractures in children J Med Ultrason vol. 40(4) pp. 443-51 
62.Burnier, M; Buisson, G; Ricard, A; Cunin, V; Pracros, JP; Chotel, F (2016) Diagnostic value of ultrasonography in elbow trauma in children: Prospective study of 34 cases Orthop Traumatol Surg Res, vol. 102(7) pp. 839-843

63.Zuazo, I; Bonnefoy, O; Tauzin, C; Borocco, A; Lippa, A; Legrand, M; Chateil, JF (2008) Acute elbow trauma in children: role of ultrasonography J. Pediatr Radiol, vol. 38(9) pp. $982-8$

64.Eckert, K; Janssen, N; Ackermann, O; Schweiger, B; Radeloff, E; Liedgens, (2014) Ultrasound diagnosis of supracondylar fractures in children Eur J Trauma Emerg Surg, vol. 40(2) pp. $159-68$

65.Pistor, G; Graffstädt, H (2003) Sonographic diagnosis of supracondylar fractures of the humerus Ultraschall Med, vol. 24(5) pp. 331-9

66.Irie T, Sono T, Hayama Y, Matsumoto T, Matsushita M. (2014) Investigation on 2331 cases of pulled elbow over the last 10 years Pediatr Rep, vol. 6(2) pp. 5090

67.Illingworth, CM (1975) Pulled elbow: a study of 100 patients Br Med J, vol. 2(5972) pp. $672-4$

68.Mohd Miswan MF, Othman MS, Muhamad Effendi F, Ibrahim MI, Rozali KN (2017) 301 Pulled/nursemaid's elbow Malays Fam Physician. Apr 30;12(1):26-28.

69.Guzel, M. salt, O: Demir:MT: Akdemir, HU: Durukan, P: Yalcin, A (2014) Comparison of hyperpronation and supination-flexion techniques in children presented to emergency department with painful pronation Niger J Clin Pract. Mar-Apr;17(2):201-4.

70.Kaplan, RE; Lillis, KA (2002) Recurrent nursemaid's elbow (annular ligament displacement) treatment via telephone Pediatrics, vol. 110(1 Pt 1) pp. 171-4 
71.Desbiolles, A; Carls, F; Dube, S; Hirsig, J Z (1987) Painful pronation--a diagnostic pitfall in septic arthritis and osteomyelitis of the elbow in infancy Kinderchir, vol. 42(3) pp. $187-9$

72.Gorman, R; Mohammed, A (2009) Osteomyelitis of the ulnar head in a presumed "pulled elbow" Emerg Med J, vol. 26(6) pp. 463-4

73.Kraus, R: Dongowski, N: Szalay, G: Schnettler, R (2010) Missed elbow fractures misdiagnosed as radial head subluxations Acta orthop Belg, vol. 76(3) pp.312-5

74.García-Mata, S; Hidalgo-Ovejero, A (2014) Efficacy of reduction maneuvers for "pulled elbow" in children: a prospective study of 115 cases J Pediatr Orthop, vol. 34(4) pp. 432-6

75. Diab HS, Hamed MM, Allam Y (2010) Obscure pathology of pulled elbow: dynamic high-resolution ultrasound-assisted classification J Child Orthop, vol. 4(6) pp. 539-43

76.Kosuwon, W; Mahaisavariya, B; Saengnipanthkul, S; Laupattarakasem, W; Jirawipoolwon, P (1993) Ultrasonography of pulled elbow J Bone Joint Surg Br. May;75(3):421-2

77. Kim, MC; Eckhardt, BP; Craig, C; Kuhns, LR (2004) Ultrasonography of the annular ligament partial tear and recurrent "pulled elbow" Pediatr Radiol, vol. 34(12) pp. 999-1004

78. Lee, YS; Sohn, YD; Oh, YT (2014) New, specific ultrasonographic findings for the diagnosis of pulled elbow Clin Exp Emerg Med, vol. 1(2) pp. 109-113

79.Sohn, Y; Lee, Y; Oh, Y; Lee, W (2014) Sonographic finding of a pulled elbow: the "hook sign" Pediatr Emerg Care, vol. 30(12) pp. 919-21

80.Khosla, S: Melton, LJ: Dekutoski, MB: Achenbach, SJ: Oberg, AL: Riggs, BL (2003) Incidence of childhood distal forearm fractures over 30 years: a population-based study JAMA, vol.290(11) pp. 1479-85 
81.Chaar-Alvarez FM, Warkentine F, Cross K (2011) Bedside ultrasound diagnosis of nonangulated distal forearm fractures in the pediatric emergency department. Pediatr Emerg Care; 27: 1027-1032.

82.Herren C, Sobottke R, Ringe MJ, (2015) Ultrasound-guided diagnosis of fractures of the distal forearm in children. Orthop Trau- matol Surg Res.; 101: 501-505.

83.Williamson D, Watura R, Cobby M. (2000) Ultrasound imaging of fore-arm fractures in children: a viable alternative? J Accid Emerg Med.17: 2224.

84.Galletebeitia Laka, I; Samson, F; Gorostiza, I; Gonzalez, A; Gonzalez, C (2017) The utility of clinical ultrasonography in identifying distal forearm fractures in the pediatric emergency department Eur J Emerg Med,

85.. Poonai, N; Myslik, F; Joubert, G; Fan, J; Misir, A; Istasy, V; Columbus, M; Soegtrop, R; Goldfarb, A; Thompson, D; Dubrovsky, AS (2017) Point-of-care Ultrasound for Nonangulated Distal Forearm Fractures in Children: Test Performance Characteristics and Patient-centered Outcomes Acad Emerg Med, vol. 24(5) pp. 607-616

86.Varga, M; Gáti, N; Kalóz, E; Bíró, Z; Szeverényi, C; Kardos, D; Józsa, G (2017) Ultrasonographic diagnosis of distal pediatric forearm fractures Orv Hetil, vol. 158(24) pp. 944-948

87.Patel DD, Blumberg, SM, Crain, EF. (2009) The utility of bedside ultra- sonography in identifying fractures and guiding fracture reduction in children. Pediatr Emerg Care 25: 221-225.

88.Dubrovsky AS, Kempinska A, Bank I, (2015) Accuracy of ultrasonography for determining successful realignment of pediatric forearm fractures. Ann Emerg Med. 65: $260-265$ 
89.Auten, JD; Naheedy, JH; Hurst, ND; Pennock, AT; Hollenbach, KA; Kanegaye, JT (2018) Comparison of pediatric post-reduction fluoroscopic- and ultrasound forearm fracture images Am J Emerg Med,

90.Kuba, MHM; Izuka, BH (2017) One Brace: One Visit: Treatment of Pediatric Distal Radius Buckle Fractures with a Removable Wrist Brace and No Follow-up Visit

91.Randsborg, PH; Sivertsen, EA (2009) Distal radius fractures in children: substantial difference in stability between buckle and greenstick fractures Acta Orthop, vol. 80(5) pp. $585-9$

92.Akar, D; Köroğlu, C; Erkus, S; Turgut, A; Kalenderer, Ö (2018) Conservative Followup of Severely Displaced Distal Radial Metaphyseal Fractures in Children Cureus, vol. 10(9) pp. e3259

93.Pien Hellebrekers, Luuk S de Vries and Tim K Timmers (2016) Displaced Distal Forearm Fractures in Children J Trauma Treat 5:4

94. McLauchlan, GJ; Cowan, B; Annan, IH; Robb, JE (2002)

Management of completely displaced metaphyseal fractures of the distal radius in children. A prospective, randomised controlled trial. J Bone Joint Surg Br, vol. 84(3) pp. 413-7

95.Handoll, HH; Elliott, J; Iheozor-Ejiofor, Z; Hunter, J; Karantana, A (2018) Interventions for treating wrist fractures in children Cochrane Database Syst Rev, vol. 12 pp. CD012470

96. Larsen, E; Vittas, D; Torp-Pedersen, S (1988) Remodeling of angulated distal forearm fractures in children Clin. Orthop. Relat. Res., vol. 237 pp. 190-5

97.Zeng, ZK; Liang, WD; Sun, YQ; Jiang, PP; Li, D; Shen, Z; Yuan, LM; Huang, F (2018) Is percutaneous pinning needed for the treatment of displaced distal radius metaphyseal fractures in children? A systematic review Medicine (Baltimore), vol. 97(36) pp. e12142 
98.Satish BR, Vinodkumar M, Suresh M, (2014) Closed reduction and K-wiring with the Kapandji technique for completely displaced paediatric distal radial fractures. Orthopedics $37: 810-6$.

99.Parikh SN, Jain VV, Youngquist J. (2013) Intrafocal pinning for distal radius metaphyseal fractures in children. Orthopedics 36:783-8.

100.Voto, SJ; Weiner, DS; Leighley, B (1990) Use of pins and plaster in the treatment of unstable pediatric forearm fractures J Pediatr Orthop, vol. 10(1) pp. 85-9

101. Tosti R, Foroohar A, Pizzutillo PD, et al. (2015) Kirschner wire infections in paediatric orthopaedic surgery. J Pediatr Orthop 35:69-73.

102.Hargreaves DG, Drew SJ, Eckersley R. (2004) Kirschner wire pin tract infection rates: a randomized controlled trial between percutaneous and buried wires. J Hand Surg Br 29:374-6.

103.Lieber J, Schmid E, Schmittenbecher PP. (2010) Unstable diametaphyseal forearm fractures. transepiphyseal intramedullary Kirschner-wire fixation as a treatment option in children. Eur J Pediatr Surg 6:395-8.

104.Lee SC, Han SH, Rhee SY, (2013) Percutaneous transphyseal pin fixation through the distal physis of the ulna in paediatric distal fractures of the forearm. J Orthop Trauma 27:462-6.

105.Compagnone, L; Ghazal, R; Canavese, F (2016) Minimally Displaced Distal Radius Fracture Treated with Closed Reduction and Percutaneous Fixation Resulting in an Iatrogenic Galeazzi Lesion J Hand Microsurg, vol. 8(3) pp. 165-169

106.Pritchett JW. (1994) Does pinning cause distal radial growth plate arrest? Orthopaedics; 17:550. 
107.Abzug JM, Little K, Kozin SH. (2014) Physeal arrest of the distal radius.

J Am Acad Orthop Surg 22:381-9.

108.Cal, H; Wang, Z; Cai, H (2016) Fixation of distal radial epiphyseal fracture: Comparison of K-wire and prebent intramedullary nail J.J. Int. Med. Res., vol. 44(1) pp. $122-30$

109.Cai, H; Wang, Z; Cai, H (2014) Prebending of a titanium elastic intramedullary nail in the treatment of distal radius fractures in children Int Surg, vol. 99(3) pp. 269-75

110.Kim, BS; Lee, YS; Park, SY; Nho, JH; Lee, SG; Kim, YH (2017) Flexible Intramedullary Nailing of Forearm Fractures at the Distal Metadiaphyseal Junction in Adolescents Clin Orthop Surg, vol. 9(1) pp. 101-108

111.Joulié S, Laville JM, Salmeron F. (2011) Posteromedial elastic stable intra- medullary nailing (ESIN) in volarly displaced metaphyso-diaphyseal distal radius fractures in child. Orthop Traumatol Surg Res; 97:330-4.

112.Schmittenbecher PP. (2005) State-of-the-art treatment of forearm shaft fractures. Injury ;36(suppl 1): A25-34.

113.Lascombes P, Haumont T, Journeau P. (2006) Use and abuse of flexible intramedullary nailing in children and adolescents. J. Pediatr Orthop 26:827-34.

114.Hans-Georg Dietz, Peter P. Schmittenbecher, Theddy Slongo, (2006) Elastic Stable Intramedullary Nailing ((ESIN) in Children AO Manual of Fracture Management. Davos: AO Publishing;

115.Nørgaard SL, Riber SS, Danielsson FB, et al. (2017) Surgical approach for elastic stable intramedullary nail in pediatric radius shaft fracture: a systematic review. J Pediatr Orthop B 27:309-14. 
116. Tokarski, J; Avner, JR; Rabiner, JE (2018) Reduction of Radiography with Point-ofCare Elbow Ultrasonography for Elbow Trauma in Children J. Pediatr.vol. 198 pp. 214219.e2

117.De Maeseneer, M; Jacobson, JA; Jaovisidha, S; Lenchik, L; Ryu, KN; Trudell, DR; Resnick, D (1998) Elbow effusions: distribution of joint fluid with flexion and extension and imaging implications Invest Radiol, vol. 33(2) pp. 117-25

118.Smith, DN; Lee, JR (1978) The radiological diagnosis of posttraumatic effusion of the elbow joint and its clinical significance: the 'displaced fat pad' sign Injury, vol. 10(2) pp. $115-9$

119.Schunk, K; Grossholz, M; Schild, H (1989) The supinator fat pad in fractures of the elbow joint] Rofo, vol. 150(3) pp. 294-6

120.. Zimmers, TE (1984) Fat plane radiological signs in wrist and elbow trauma Am J Emerg Med, vol. 2(6) pp. 526-32

121.. Goswami, GK (2002) The fat pad sign Radiology, vol. 222(2) pp. 419-20

122.Irshad, F; Shaw, NJ; Gregory, RJ (1997) Reliability of fat-pad sign in radial head/neck fractures of the elbow Injury, vol. 28(7) pp. 433-5

123.Hall-Craggs, MA; Shorvon, PJ; Chapman, M (1985) Assessment of the radial headcapitellum view and the dorsal fat-pad sign in acute elbow trauma AJR Am J Roentgenol, vol. $145(3)$ pp. $607-9$

124.de Beaux, AC; Beattie, T; Gilbert, F (1992) Elbow fat pad sign: implications for clinical management J R Coll Surg Edinb, vol. 37(3) pp. 205-6 
125.Miles, KA; Lamont, AC (1989) Ultrasonic demonstration of the elbow fat pads Clin Radiol, vol. 40(6) pp. 602-4

126. Yousefzadeh, DK; Jackson, JH (1978) Lipohemarthrosis of the elbow joint Radiology, vol. $128(3)$ pp. $643-5$

127.Dohi, D (2013) Confirmed specific ultrasonographic findings of pulled elbow J Pediatr Orthop, vol. 33(8) pp. 829-31

128.Eismann, EA; Cosco, ED; Wall, EJ (2014) Absence of radiographic abnormalities in nursemaid's elbows J Pediatr Orthop, vol. 34(4) pp. 426-31

129.Scapinelli, R; Borgo, (2005) A Pulled elbow in infancy: Diagnostic role of imaging Radiol Med, vol. 110(5-6) pp. 655-64

130.Frumkin, K (1985) Nursemaid's elbow: a radiographic demonstration Ann Emerg Med, vol. 14(7) pp. 690-3

131.Rabiner, JE; Khine, H; Avner, JR; Tsung, JW (2015) Ultrasound findings of the elbow posterior fat pad in children with radial head subluxation Pediatr Emerg Care, vol. 31(5) pp. $327-30$

132. Little JT, Klionsky NB, Chaturvedi A, et al. (2014) Pediatric distal forearm and wrist injury: an imaging review. Radiographics 34: 472-490.

133.Kwon, SW; Hong, SJ; Nho, JH; Moon, SI; Jung, KJ (2018) Physeal fracture in the wrist and hand due to stress injury in a child climber: A case report Medicine (Baltimore), vol. $97(34)$ pp. e11571

134. Johnson CW, Carmichael KD, Morris RP, et al. (2009) Biomechanical study of flexible intramedullary nails. J Pediatr Orthop 2009; 29:44-8. 
135.Mahar A, Sink E, Faro F, et al. (2007) Differences in biomechanical stability of femur fracture fixation when using titanium nails of increasing diameter. J Child Orthop 1:2115 .

136.Kaiser MM, Zachert G, Wendlandt R, et al. (2012) Increasing stability by pre- bending the nails in elastic stable intramedullary nailing: a biomechanical analysis of a synthetic femoral spiral fracture model. J Bone Joint Surg Br 94:713-8.

137.Kim YJ, Lee JH, Baek JH. (2016) Variant course of extensor pollicis longus tendon in the second wrist extensor compartment. Surg Radiol Anat 38:497-9.

138.De Maeseneer M, Marcelis S, Osteaux M, et al. (2005) Sonography of a rupture of the tendon of the extensor pollicis longus muscle: initial clinical experience and correlation with findings at cadaveric dissection. AJR Am J Roentgenol 184:175-9.

139. Hu CH, Fufa D, Hsu CC, et al. (2015) Revisiting spontaneous rupture of the extensor pollicis longus tendon: eight cases without identifiable predisposing factor. Hand (N Y) 10:726

140. Lepage D, Tatu L, Loisel F, et al. (2015) Cadaver study of the topography of the musculotendinous junction of the finger extensor muscles: applicability to tendon rupture following closed wrist trauma. Surg Radiol Anat 2015; 37:853-8.

141. Engkvist O, Lundborg G. (1979) Rupture of the extensor pollicis longus tendon after fracture of the lower end of the radius - a clinical and microangiographic study. Hand 1979; $11: 76-86$.

142.Lee SK, Bae KW, Choy WS. (2013) Use of the radial groove view intra-operatively to prevent damage to the extensor pollicis longus tendon by protruding screws during volar plating of a distal radial fracture. Bone Joint J 95-B:1372-6.

143Song D, Evans R, Arneja JS. (2013) Delayed extensor pollicis longus tendon rupture following nondisplaced distal radius fracture in a child. Hand (N Y) 2013; 8:242 4 . 
144.Mansour AA, Watson JT, Martus JE. (2013) Displaced dorsal metaphyseal cortex associated with delayed extensor pollicis longus tendon entrapment in a pediatric Smith's fracture. J Surg Orthop Adv 22:173-5.

145.Lee AK, Beck JD, Mirenda WM, et al. (2016) Incidence and risk factors for extensor pollicis longus rupture in elastic stable intramedullary nailing of pediatric forearm shaft fractures. J Pediatr Orthop 36:810-5.

146.Kay RM, Khounganian GS, Stevanovic M. (2004) Late extensor pollicis longus rupture following displaced distal radius and ulna fractures in a child. J Orthop Trauma 18:53-6.

147. Kruppa C, Bunge P, Schildhauer TA, et al. (2017) Low complication rate of elastic stable intramedullary nailing (ESIN) of pediatric forearm fractures: a retrospective study of 202 cases. Medicine (Baltimore)

148. Stahl S, Calif E, Eidelman M. (2007) Delayed rupture of the extensor pollicis longus tendon following intramedullary nailing of a radial fracture in a child. J Hand Surg Eur Vol $32: 67-8$.

149. Brooker B, Harris PC, Donnan LT, et al. (2014) Rupture of the extensor pollicis longus tendon following dorsal entry flexible nailing of radial shaft fractures in children. J Child Orthop 8:353-7

150.Gibbon E, Beranger JS, Bachy M, et al. (2015) Influence of the bending of the tip of elastic stable intramedullary nails on removal and associated complications in pediatric both bone forearm fractures: a pilot study. Int J Surg 16:19-22. 


\title{
Short, double elastic nailing of severely displaced distal pediatric radial fractures
}

A new method for stable fixation

\author{
Marcell Varga, MDa , Gergổ Józsa, MD ${ }^{\mathrm{c},}$, Balázs Fadgyas, MD ${ }^{\mathrm{b}}$, Tamás Kassai, MDª, Antal Renner, MDª
}

\begin{abstract}
Rationale: Short double elastic nailing is a minimal invasive, modified ESIN (elastic stable intramedullary nailing) technique for severely displaced distal radial fracture in children. The aim of this technical report is to introduce our new method and eva uate the final results of the procedure.

Patient concerns: We reviewed retrospectively 24 patients who underwent short double elastic nailing due to distal radial fractures between November 2012 and December 2015. Indications for surgery included closed, severely displaced, unstable metaphyseal or diametaohyseal fractures of the radius.

Intervention: The fractures were stabilized by 2 prebent short elastic titanium nails inserted from the distal side of the fracture. In cases of associated unar fracture, a classic anterograd ESIN nailing was also performed. Patients were mobilized immediately in a removable short splint which was removed after 1 to 2 weeks. There has been no additional splinting or casting.

Outcomes: There were 17 males and 7 females with an average age of 9.8 years (range, 4-16 years). The right hand was involved in 16 cases and the left hand in 8 cases. The average follow-up was 17.8 months (range, $7-28$ months). Of the 24 patients, 3 presented irritation of the skin, which resolved after removal of the radial nail. All the patients regained full range of motion without any complications.

Lessons: Our technique is an effective, safe, and easily learnable procedure for unstable fractures of the distal third of the radius. It achieves good functional and radiological results, and allows early mobilization without the need of casting. Avoiding the physeal plates, we reduce the risk of iatrogenic postoperative deformity. Further prospective and biomechanical investigations are necessary to verify our experience.
\end{abstract}

Abbreviations: $\mathrm{ESIN}=$ elastic stable intramedullary nailing, $\mathrm{K}$-wire $=$ Kirschner wire.

Keywords: children, ciametaphyseal radial fracture, distal forearm fracture, elastic nail

\section{Introduction}

Distal and severely displaced pediatric metaphyseal radial fractures with total rupture of the periosteum are generally considered unstable. ${ }^{|1|}$ Although the remodeling potential of distal radius fractures is very good in childhood, a subgroup of severely displaced and unstable distal pediatric forearm fractures are candidates for operative fixation because acceptable reduction cannot be maintained in a conservative way.

\section{Editor: Johannes Mayr.}

The authors have no funding and conflicts of interest to disclase.

a Sándor Péterfy Street Hospital and Casualty Centre, ${ }^{b}$ Surgical Department of Heim Pál Children's Hospital, Budapest, ' Department of Pediatrics, Surgical Unit, University of Pécs, Pécs, Hungary.

"Correspondence: Gergö Józsa, Department of Pediatrics, Surgical Unit. University of Pécs, 7 Júzsef A. Sir. Pécs H.7623, Hungary

(e-maî: dr.jozsa.gergo@gmail.com)

Copyright 92017 the Author(s). Published by Wolters Kuwer Health, Inc. This is an open access article distnbuted under the Creative Commons Attribution License 4.0 (CCBY), which permits unrestricted use, distribution, and reproduction in any medium, provided the original work is properly cited.

Medicine (2017) 96:14(e6532)

Received: 2 January 2017 / Received in final form: 10 March 2017 / Accepted: 14 March 2017

http://2x.dol.org/10.1097/MD.0000000000006532
These injuries are usually candidates for closed reduction and minimal invasive fixation. ${ }^{[1-5]}$ Operative osteosynthesis technique of pediatric wrist fractures is optimally minimally invasive, physis sparing, and maintains an acceptable and painless reduction.

Many of these techniques do not respect physeal plates. ${ }^{[2,6]}$ Most operative methods need complementary 4 to 6 weeks of postoperative immobilization by casting. ${ }^{[1-7]}$

Current available techniques (modifications of Kirschner wiring or conventional elastic stable intramedullary nailing [ESIN]) have about the same rate of mild complications. Growth disturbance is a rare, but represents a very rare severe complication of transepiphyseal wire placement. Considering this fact and the drawback of the 4 to 6 weeks of cast immobilization of the conventional techniques, we looked for a solution which eliminates these problems.

In our report, we would like to introduce our modified ESIN method for operative treatment of severely displaced pediatric distal metaphyseal or metadiaphyseal radial fractures.

With 2 short and prebent, retrograde elastic titanium nails inserted proximal to the distal radial physis, a very stable stabilization can be achieved without the need for a prolonged period of cast immobilization. The nails do not cross the physeal plates, so the possibility of postoperative physeal arrest is reduced. 


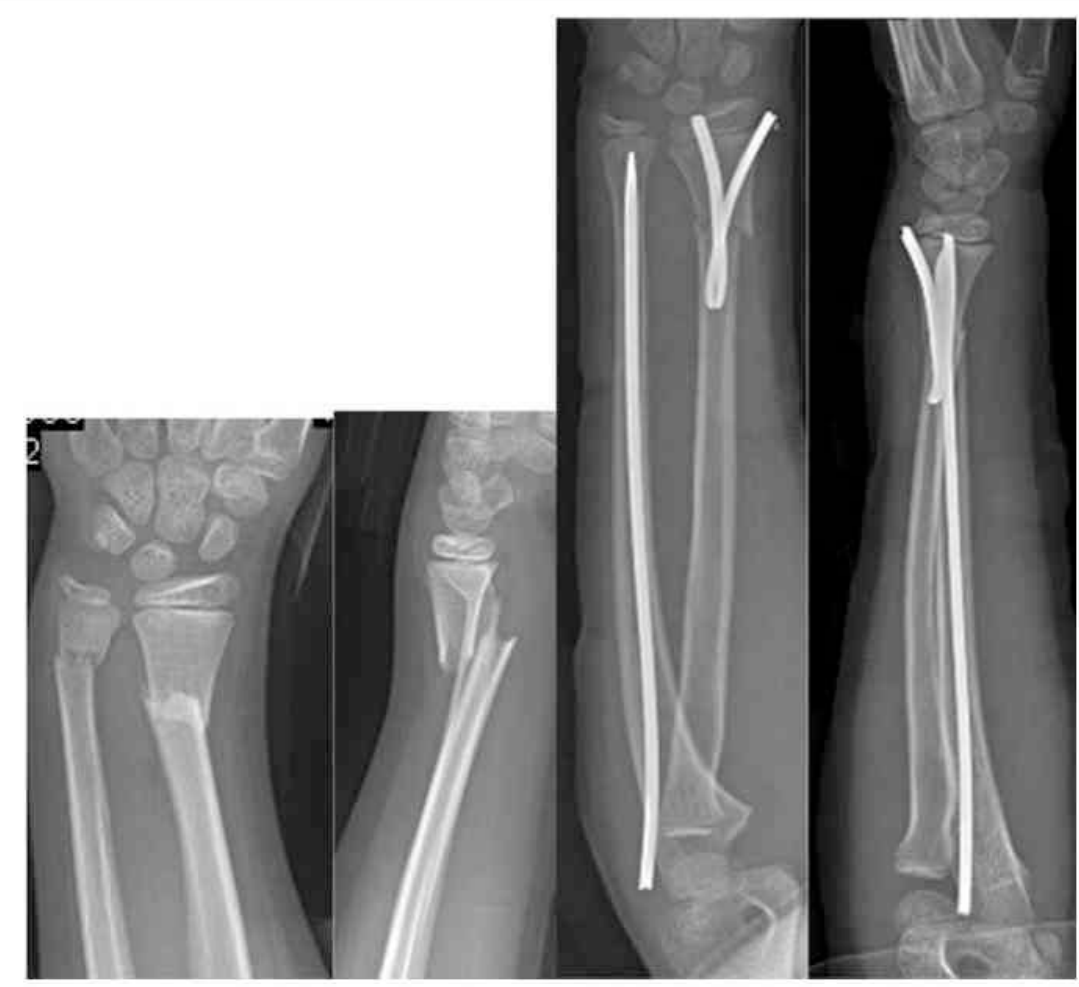

Figure 1. Pre- and postoperative $x$-rays of displaced distal forearm fracture.

\section{Patients and methods}

We reviewed retrospectively 24 patients who underwent operations due to severely displaced distal forearm or diametaphyseal radial fracture between November 2012 and December 2015. All patients were treated with short double prebent intramedullary nails. Fifteen patients had isolated radial, and 9 children had associated ulnar fracture as well. There were 17 boys and 7 girls with an average age of 9.8 years (range, 6-16 years). The right hand was involved in 16 cases and the left hand in 8 cases. Indications for surgery included closed fractures with total radial or dorsal displacement and shortening. We excluded open fractures, physeal injuries, and pathological fractures. All procedures were performed under general anesthesia and C-arm image intensifier control. A single-shot antibiotic prophylaxis was routinely used. All children were treated by 3 surgeons experienced in the ESIN and percutaneous pinning technique as well. The parents were informed about other treatment options. We began immediately with a postoperative mobilization program and applied a short removable splint. The degree of anatomic reduction was confirmed on plain radiographs obtained at the first, fourth week, and sixth month postoperatively. Nails were removed 6 to 36 weeks after the operation in general anesthesia or in local anesthesia. Average follow-up was 17.8 months (range, 7-28 months).

Considering the fact that our method is a modification and special application of the conventional and existing ESIN technique, an ethical approval was not requested by the Ethical Committee of our institutions for this retrospective study. Clinical application of the modified technique has been accepted and permitted in 2009 by our medical review board by the Hungarian
Pediatric Trauma Committee and by the Hungarian Pediatric Surgery Committee. Possible benefits, risks, and complications, along with other methods, were explained to all parents of each child, and an informed consent was obtained by them.

\section{Operative technique}

Patients are under general anesthesia. The arm is extended and placed in a pronated position on a fluoroscopically translucent table. X-ray images of the lateral position and anteroposterior position before operation are shown in (Figs. 1 and 2). The first step is closed reduction under image intensifier. If reduction cannot be achieved by single manual manipulation a 2 to $3 \mathrm{~mm}$ diameter Kirschner wire ( $\mathrm{K}$-wire) or sharp elastic nail is inserted to the fracture gap from a dorsal stab incision. Using the pin as a lever arm, the distal fragment is raised up and slid forward onto the proximal end. After successful reduction, we determine the insertion points of the short elastic nails. The first is the dorsal site of distal radius, the area of Lister tubercle, just proximal to the physeal line of the radius. After skin incision, we gently dissect the soft tissues, and with an awl we open the medullary canal. A " $\mathrm{C}$ "shaped prebent short and relatively thick $(8-12 \mathrm{~cm}$ long and $2.5-3.5 \mathrm{~mm}$ diameter) titanium elastic nail is inserted into the distal medullary canal of the radius. The nail is gently moved forward along its curvature until its distal end enters the medullary canal of the proximal fragment. Then moderate force is applied, and the nail tip becomes impacted. In this position, the convex side of the nail faces the fracture line of the anterior cortex when observing from a lateral view. After insertion of the first nail, we determine the entry point for the second one. It is the distal radial site of the radius, just proximal to the growth plate. 


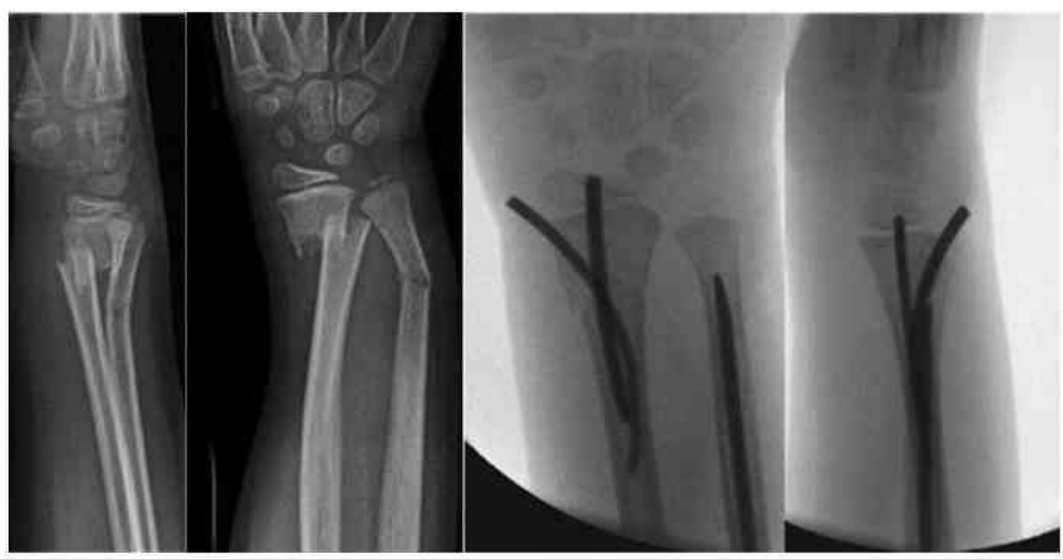

Figure 2. Pre- and postoperative $x$-rays of displaced distal forearm fracture.

The second nail is usually thinner $(2-2.5 \mathrm{~mm}$ in diameter) and also prebent to a "C"-form shape. Similarly to the technique described above, this nail is advanced forward along a radioulnar and distal to proximal curvature. After reaching the medullary canal of the proximal fragment, the nail is pushed further with a controlled force, until tightness is achieved. Observing from an $\mathrm{AP}$-view, the convex side of the nail faces the ulnar cortex of the radius (Fig. 3). If the prebent curve of the short nail is not sufficient (the " $\mathrm{C}$ " shape is too flat), the end of the nail will get stuck in the ventral cortex. An overbent nail end, however, cannot be inserted into the proximal medullary canal. In this situation, the nail is pulled back, and the degree of the curvature is corrected. By pushing forward a malpositioned nail, an additional iatrogenic ventral or dorsal cortical fracture can occur, so it is forbidden to use uncontrolled force during nail insertion.

\subsection{Postoperative care}

The first 1 to 2 weeks, a short, removable splint is applied. Sport and hard physical activity is restricted for 6 weeks, but full range of movement can begin within a few days.

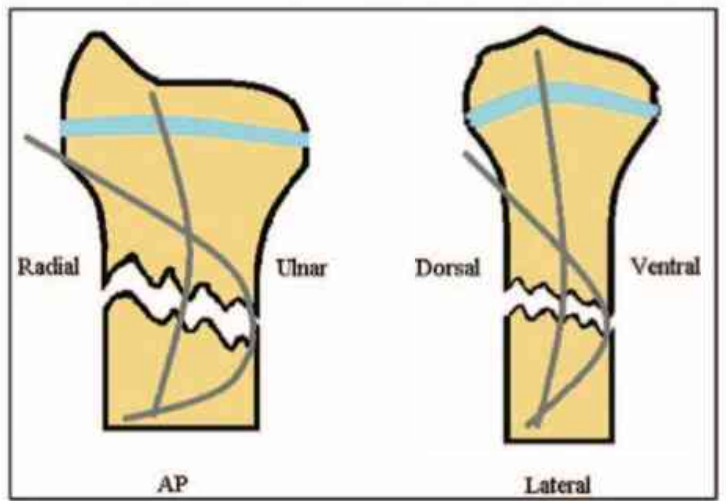

Figure 3. Position of the prebend short elastic nail is shown in the semantic picture.

\section{Results}

Of the 24 patients, 3 presented irritation of the skin, which resolved after a relatively early removal of the radial nail. In the sixth postopertive week, all patients regained full range of motion. We have not observed any infection, tendon, nerve, or growth plate injury during the follow-up time. Average operational time was 19 minutes (range, 7-53 minutes). The necessary splinting time was reduced to an average 1 to 2 weeks. Usually, a short removable splint was sufficient for early pain-free mobilization. In the follow-up x-rays of the patients, 20 cases were considered as anatomic, 2 as good, and 2 as acceptable reduction. All the $\mathrm{x}$-rays made 6 months postoperatively showed anatomic reduction, and there has been no sign of growth disturbance at the area of the distal radius.

\section{Discussion}

The gold-standard operative method for pediatric distal radial fracture is closed reduction and percutaneous pinning. ${ }^{\mid 2-8]}$ Although the many variations of percutaneous pinning are simple and effective in unstable distal radial fractures, they bear many potential complications and disadvantages as well..$^{[8-12]}$ Kirschner-wire-related complications are well known: migration of the pins, superficial infections, damage to the growth plate, skin irritation, and insufficient biomechanical ability to maintain the reduction without casting. ${ }^{[8-10,13-15]}$ This latter fact is the main drawback of this technique: in addition to the discomfort associated with operation, it is usually necessary to wear a long or short cast at least for 4 to 6 weeks postoperatively..$^{\mid 2,3,5-9]}$ Fractures in the area of the diametaphyseal junction represents a special problem: they are usually located too distally to be treated by classic ESIN and too proximal for conventional Kirschner wire fixation. ${ }^{[2,6]}$ Lieber et al ${ }^{[2]}$ used transepiphyseal pinning in these cases. Although the chance of a iatrogenic physeal injury is very small, a physeal arrest and progressive deformity can be a potential complication of any transepiphyseal stabilization. ${ }^{[13-15]}$ Others suggest a specially prebent long, physis-sparing elastic nail to eliminate this problem. ${ }^{[16-18]}$ All of these methods require postoperative plaster-cast immobilization..$^{[2,6,16-18]}$ Analyzing our own cases of pediatric distal radial fractures treated by percutaneous pinning between 2008 and $2014(\mathrm{n}=184)$, we found a total complication rate of $16.84 \%$ retrospectively. 
Superficial infection occurred in 8 children, skin irritation in 14 , migration of the wires in 5 cases, unacceptable redislocation in 2 cases, and growth disturbance and postoperative deformity in 2 cases.

Using double elastic nailing, we have observed only mild complications like skin irritation which was caused by the end of the dorsally inserted and relatively too long nail under the skin. We hypothesize that this problem can be attributed to improper cutoff of nails during the learning curve period of the technique. When nails are cut in a maximally palmar-flexed position of the wrist just below the level of the skin, this irritation problem ceases.

Cutting off the nails outside the skin is also a possibility to eliminate this complication, although until now we sank each nails under the skin.

Anatomical reduction is not an absolute requirement treating these kinds of fractures due to the remodeling capacity of the distal radius. More severe dislocations (more than $30-40^{\circ}$ ) and older children (boys aged $>12$ years and girls aged $>10$ years) need reduction to the range of the remodeling capacity. K-wire osteosynthesis needs additional cast immobilization. Redislocation can occur even with properly applied casting and wiring because certain types of fractures (i.e., diametaphyseal configuration) are highly unstable. The x-ray results of our technique were all within the remodeling range, and they did not show even minimal tendency of redislocation. This indicates the superior stability of double elastic nailing to percutaneous pinning.

Our technique is a modification of the classic ESIN method. The biomechanical principles are the same as for long diaphyseal fractures, which are symmetrical splinting by 2 elastic nails, each supporting the inner cortex. ${ }^{[19-23]}$ The main difference is the length and the precontoured curve of the nails.

Ideally, the highest point of convexity of titanium elastic nails is at the level of the fracture symmetrically opposite each other. ${ }^{[23]}$ By long nails, it is directed toward the central region of the diaphysis, so in the cases of metaphyseal or diametaphyseal fracture, it would be very eccentric from the fracture line. Using short "C-shaped and mini" nails, the maximal curve is at the fracture, and the tension within the nail provides an optimal memory effect. The 2 nails ensure a long contact area with the inner cortex, which is mandatory for axial stability. Using 2 nails from different entry points, but from the same level, provides rotational, translational, and bending/bowing stability. We hypothesize that "short" ESIN nails inserted at the distal metaphyseal area works the same way as conventional ESIN in a shaft fracture. In an animal scudy, Johnson et $\mathrm{al}^{[19]}$ have shown that at $3 \mathrm{~mm}$ diameters or more beyond the fracture site, the length of the nail does not significantly affect the biomechanical properties of the construct.

We use thicker nails compared to conventional techniques. This is necessary because short nails have the greatest tensing effect in the broad diametaphyseal zone of the radius. For the second nail, we usually choose a smaller one because its main role is to add more rotational stability and thus we minimize the chance of a potential iatrogenic fracture. We have experienced differences in rotational stability using a thinner $(2-2.5 \mathrm{~mm})$ second nail, but insertion was easier. If we choose a thinner first nail $(1.5-2 \mathrm{~mm})$, flexion-extension stability significantly decreased. Stability was tested under intraoperative fluoroscopy in maximally dorsal-extended and palmar-flexed position of the hand. We achieved the best stability with combination of 2.5 to 3 and 2 to $2.5 \mathrm{~mm}$ nail diameters.
The insertion points (Lister tubercle and radiodorsal side of the radius) are the classic places for the insertion of conventional ESIN nails, located proximal to the physis, thus avoiding the possibility of iatrogenic growth plate injury. It is very important to visualize the dorsal and radial entry point adequately to avoid iatrogenic injury to the long extensor pollicis tendon and the superficial radial nerve. Incorrect insertion points or malpositions of the entry holes can jeopardize the physeal plates, the sensory branch of the radial nerve, or the tendons, which are also potential complications of the classic ESIN method..$^{[24-27]}$ Advantages of our technique are the early mobilization with a short splint and the elimination of potential growth plate injury. We think that our technique is a minimally invasive, easily learnable alternative operative method, when compared to percutaneous pinning in metaphyseal, and plate or transepiphyseal osteosynthesis in cases of diametaphyseal-displaced fractures of the forearm of radius. Further prospective and biomechanical studies are required to verify our initial experience.

\section{References}

[1] Bae DS, Waters PM. Pediatric distal radius fractures and triangular fibrocartilage complex injuries. Hand Clin 2006;22:43-53.

[2] Lieber J, Schmid E, Schmittenbecher PP. Unstable diametaphyseal forearm fractures. transepiphyseal intramedullary Kirschner-wire fixation as a treatment option in children. Eur J Pediarr Surg 2010;6:395-8.

[3] Satish BR, Vinodkumar M, Suresh M, et al. Closed reduction and Kwiring with the Kapandji technique for completely displaced paediatric distal radial fractures. Orthopedics 2014;37:810-6.

[4] Sano K, Hashimoto T, Kimura K, et al. Percutaneous flexible double pinning (Py-Desmanet's procedure) for paediarric distal radius fractures. Hand 2013;8:392-6.

[5] Parikh SN, Jain VV, Youngquist J. Intrafocal pinning for distal radius metaphyseal fractures in children. Orthopedics 2013;36:783-8.

[6] Lieber J, Sommerfeldt DW. Diametaphyseal forearm fracture in childhood. Pitfalls and recommendations for treatment. Unfallchirurg 2011;114:292-9.

[7] Lee SC, Han SH, Rhee SY, et al. Percutaneous transphyseal pin fixation through the distal physis of the ulna in paediatric distal fractures of the forearm. J Orthop Trauma 2013;27:462-6.

[8] Wendling-Keim DS, Wieser B, Dietz HG. Closed reduction and immobilization of displaced distal radial fractures. Method of choice for the treatment of children? Eur J Trauma Emerg Surg 2015;41:421-8.

[9] Tosti R, Foroohar A, Pizzutillo PD, et al. Kirschner wire infections in paediatric orthopaedic surgery. J Pediatr Orthop 2015;35:69-73.

[10] Subramanian P, Kantharuban S, Shilston S, et al. Complications of Kirschner-wire fixation in distal radius fractures. Tech Hand Up Extrem Surg 2012;16:120-3.

[11] Hargreaves DG, Drew SJ, Eckersley R. Kirschner wire pin tract infection rates: a randomized controlled trial between percutaneous and buried wires. J Hand Surg Br 2004;29:374-6.

[12] Schmittenbecher PP. State-of-the-art treatment of forearm shaft fractures. Injury 2005;36:A25-34.

[13] Abzug JM, Little K, Kozin SH. Physeal arrest of the distal radius. J Am Acad Orthop Surg 2014;22:381-9.

[14] Boyden EM, Peterson HA. Partial premature closure of the distal radial physis associated with Kirschner wire fixation. Orhopedic 1991;14:585-8.

[15] Pritchett JW. Does pinning cause distal radial growth plate arrest? Orthopaedics 1994;17:550.

[16] Cai H, Wang Z, Cai H. Prebending of a titanium elastic intramedullary nail in the treatment of distal radius fractures in children. Int Surg 2014;99:269-75.

[17] Joulié S, Laville JM, Salmeron F. Posteromedial elastic stable intramedullary nailing (ESIN) in volarly displaced metaphyso-diaphyseal distal radius fractures in child. Orthop Traumatol Surg Res 2011;97:330-4.

[18] Ge YH, Wang ZG, Cai HQ, et al. Pre-bent elastic stable intramedullary nail fixation for distal radial shaft fractures in children. Orthop Surg 2010;2:229-33. 
[19] Johnson CW, Carmichael KD, Morris RP, et al. Biomechanical study of flexible intramedullary nails. J Pediatr Orthop 2009;29:44-8.

[20] Mahar A, Sink E, Faro F, et al. Differences in biomechanical stability of femur fracture fixation when using titanium nails of increasing diameter. J Child Orthop 2007;1:211-5.

[21] Mehlman CT, Nemeth NM, Glos DL. Antegrade versus retrograde titanium elastic nail fixation of paediatric distal-third femoralshaft fractures: a mechanical study. J Orthop Trauma 2006;20:608-12.

[22] Kaiser MM, Zachert G, Wendlandr R, et al. Increasing stability by prebending the nails in elasticstable intramedullary nailing: a biomechanica analysis of a synthetic femoral spiral fracture model. J Bone Joint Surg Br 2012;94:713-8.
[23] Dietz HG, Schmittenbrecher P, Slongo T, et al. Elastic Stable Intramedullary Nailing in Children. Thieme, Switzerland:2006.

[24] Bukvić N, Marinović M, Bakota B, et al. Complications of ESIN osteosynthesis-experience in 270 patients. Injury 2015;46:\$40-3.

[25] Nisar A, Bhosale A, Madan SS, et al. complications of elastic stable intramedullary nailing for treating paediatric long bone fractures. J Orthop 2013;10:17-24.

[26] Brooker B, Harris PC, Donnan I, et al. Rupture of the extensor pollicis longus tendon following dorsal entry flexible nailing of radial shaft fractures in children. J Child Orthop 2014;8:353-7.

[27] Stahl S, Galif E, Eidelman M. Delayed rupture of the extensor pollicis longus tendon following intramedullary nailing of a radial fracture in a child. J Hand Surg Eur Vol 2007;32:67-8. 


\title{
Intraoperative sonography may reduce the risk of extensor pollicis longus tendon injury during dorsal entry elastic intramedullary nailing of the radius in children
}

\author{
Marcell Varga, MD ${ }^{a}{ }^{*}$, Nikoletta Gáti, MDa ${ }^{a}$ Tamás Kassai, MDa ${ }^{a}$ Szilvia Papp, MD ${ }^{a}$, Sándor Pintér, MD, PhD
}

\begin{abstract}
Extensor pollicis longus tendon (EPL) injury is a potential complication of dorsal entry radial elastic nailing technique in children. The aim of this study was to investigate if intraoperative ultrasonographic guidance can reduce the risk of (EPL) injury.

Correlation between sonographic and operative findings were examined first in 6 adult cadavers. Position of Lister's tubercle, EPL, and extraosseal end of the elastic nail were detected by ultrasound imaging during a minimally invasive dorsal entry nailing. Radial slope of Lister's eminence was determined as a safe and easily identifiable entry point for opening the medullary canal. Extraosseal ends of the nails were bended in a slight radial direction and cut immediately beneath the skin in a maximally palmar-flexed wrist position. Cadaveric dissections followed our procedures all correlated with ultrasonographic findings, we have not seen tendon damage, obstruction or friction by the implant's end.

After cadaveric experiments, we began using intraoperative sonography for monitoring elastic nail insertion in pediatric radial fractures

Between January 2015 and November 2016, 77 pediatric closed diaphyseal radial fractures were operated by dorsal aoproach ESIN under intraoperative sonographic checking.

Procedures were executed by 2 orthopedic surgeons experienced in ESIN technique with basic musculoskeletal ultrasonographic qualifications.

Sonographic identification of EPL and Lister's tubercle in the transverse view was possible in all cases. Determination of the position of the nail end to EPL was also possible in all cases. Mean distance of the transverse view center of the EPL and nail was $0.49 \mathrm{~cm}$ (range $0.3-0.62 \mathrm{~cm}, S D=0.66$ ). Based on the sonographic transverse view, the operator decided repositioning the nails by 2 patients.

We have not found EPL injury postoperatively. All patients were followed for at least 12 months after operations. Nails were removed in all children without further complications.

Intraoperative sonography helps determining optimal insertion point and the risk of EPL injury may be reduced during dorsal entry approach.

Although the procedure is relatively easy, authors take note that surgical and sonoanatomic knowledge, basic sonographic skills and experience in the ESIN technique are equally necessary for its successful application. A greater number of cases is necessary to confirm our initial promising experiences.
\end{abstract}

Abbreviations: $E C R B=$ extensor carpi radialis brevis tendon, $E C R L=$ extensor carpi radialis longus tendon, $E P L=e x t e n s o r$ pollicis longus tendon, ESIN = elastic stable intramedullary nailing, LT = Lister's tubercule.

Keywords: children, corsal entry elastic nailing, EPL, ESIN, extensor pollicis longus tendon injury, radius fracture

\section{Introduction}

Flexible intramedullary nailing (ESIN) of displaced and unstable forearm diaphyseal fractures has become the gold standard operative method in children in the past decades. ${ }^{[1,2]}$

\section{Editor: Johannes Mayr.}

Level of evidence: $N$. Therapeutic

The authors have no conflicts of interest to disclose.

a Peterty Hospital, Department of Pediatric Trauma Surgery, Budapest,

${ }^{b}$ Department of Trauma Surgery, University Of Szeged, Hungary.

Correspondence: Marcell Varga Péterfy Hospital, Department of Pediatric Trauma Surgery, Budapest, Hungary (e-mail: drvmarcel@mail.com). Copvright $@ 2018$ the Author(s). Published by Wolters Kluwer Health, Inc. This is an open access article distributed under the Creative Commons Attribution License 4.0 (CCBY), which permits unrestricted use, distribution, and reproduction in any medium, provided the original work is property cited.

Medicine (2018) 97:24(e11167)

Received: 3 January 2018 / Accepted: 17 May 2018

http://2x.dol.org/10.1097/MD.0000000000011167
Elastic stable intramedullary nailing of the radius can be carried out from 2 entry points. These are the radial (distal radial side proximally from physis) and the dorsal approaches (through Lister's tubercle) ${ }^{[3]}$ (Fig. 1A and B).

Both approaches have potential complications. Radial entry point can cause a $2.9 \%$ rate of transient and $0.3 \%$ rate of permanent injury to the superficial branch of the radial nerve whereas dorsal approach can have a $2.6 \%$ rate of extensor pollicis longus tendon rupture. ${ }^{[4]}$ Due to the consequences of these complications, recent studies and the original description advocate using the lateral approach. ${ }^{\{3,5,6]}$

Considering that lateral entry ESIN technique is disadvantageous in distal radial diaphyseal fractures and radial nerve may be a source of painful neuroma, ${ }^{[4,7]}$ we were searching for safer ways to reduce the risk of the dorsal approach.

We hypothesized that ultrasonographic checking of the EPL and positioning the end of the nail during insertion in a safe zone can reduce the risk of any damage. 

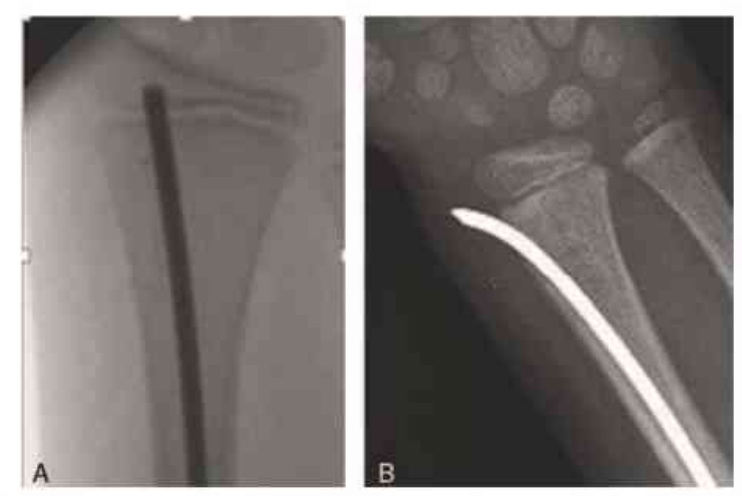

Figure 1. (A) $X$-ray of dorsal entry elastic nailing. (B) $X$-ray of radial entry elastic nailing.

\section{Methods}

Approval of the cadaveric and intraoperative diagnostic study was permitted by our Institutional Medical Board in 2014 November. Ethical permission for cadaveric experiments and clinical use of intraoperative sonography was approved by the Ethics Committee of Péterfy Hospital, in 2014, December.

First, we performed cadaveric examinations on six adult humans.

EPL and Lister's tubercle was visualized by high frequency (14$20 \mathrm{MHz}$ ) ultrasound imaging.

After sonographic determination of the insertion points, we positioned an elastic nail through Lister's tubercle according to standard dorsal technique. Position of the EPL relative to the elastic nail was examined from transverse and longitudinal planes.

We bent the extraosseal end of the nail in a slight radial direction and cut beneath the skin in a maximally palmar-flexed wrist position.

This was followed by preparation of the area and comparing the sonographic and anatomic findings (Fig. 2).

Cadaveric dissections all correlated with ultrasonographic findings: distance of EPL and nail was median $0.5 \mathrm{~cm}$ (range: $4.4-$ $5.2 \mathrm{~cm}$ ) clinically, and $0.48 \mathrm{~cm}$ (range: $0.44-0.5 \mathrm{~cm}$ ) sonographically. There was no tendon damage, obstruction or friction.

Following our cadaveric experience, we began using intraoperative ultrasound during elastic nailing of pediatric radial fractures.

A written informed consent was obtained from the parents of all patients.

Between January 2015 and November 2016, 77 radial fractures were operated by dorsal entry elastic nailing with ultrasonic guidance. Inclusion criteria were children with closed and displaced radial or forearm fractures which were candidates for operative ESIN technique. We excluded children with closed growth plates, open fractures and comminuted fractures which could not be stabilized by intramedullary nailing. Patients' age were between 4 and 15 years and had closed and displaced radial or forearm fractures with open growth plates.

We used aseptically isolated high frequency linear probes and sterile gel for the intraoperative technique. First, we determined the insertion point. After skin incision and soft tissue separation, we targeted the radial slope of Lister's tubercle with a sharp

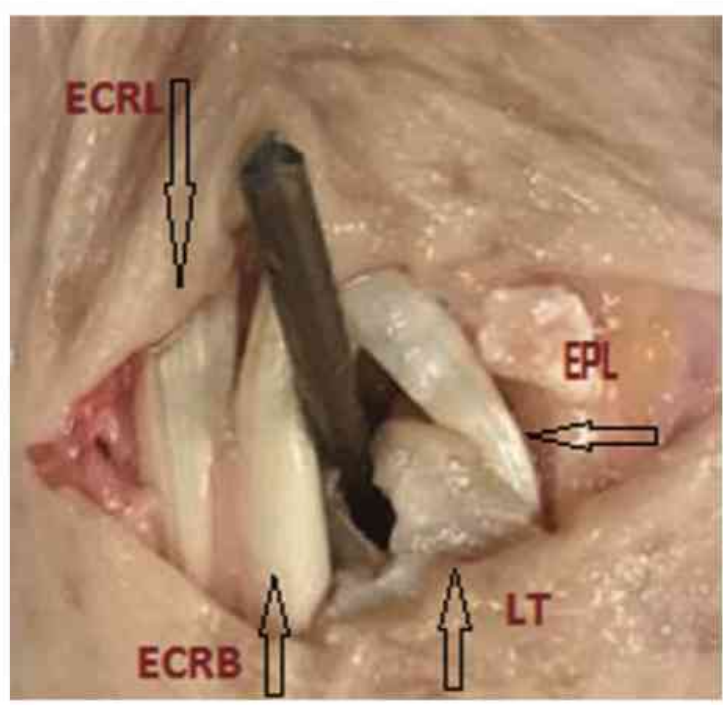

Figure 2. Relation of the end of the nail to the surrounding structures in dorsal approach. (adult cadaveric preparation) $E C R L=e x t e n s o r$ carpi radialis longus tendon, $E C R B=$ extensor carpi radialis brevis tendon, $L T=$ Lister's tubercule.

Kirschner wire (Fig. 3). After we pressed the wire softly to the bone we checked its position with image intensifier and ultrasound. Medullary canal opening with a sharp awl was also monitored sonographically and an elastic nail of 2 to $2.5 \mathrm{~mm}$ diameter was inserted.

Operative technique and fracture reduction were made according to standard protocol. ${ }^{|3|}$

After cutting the end of the nail, we rechecked its position relatively to Lister's tubercle.

EPL has been also checked in longitudinal and transverse plane, we analyzed its relation to the extraosseal part of the nail (Figs. 4-6).

Continuity of the tendon has been checked by dynamic examination while passively flexing and extending the wrist and the thumb.

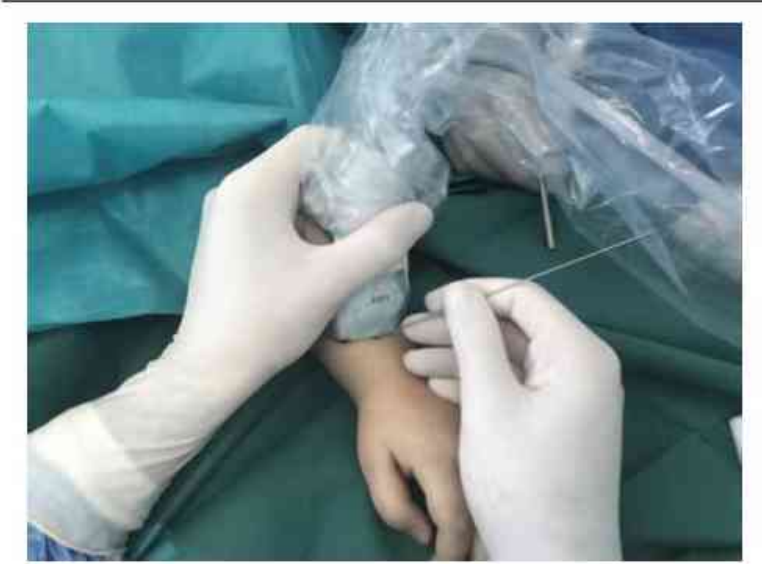

Figure 3. Sonography-assisted aiming of the radial side of Lister's tubecule with a K-wire. 


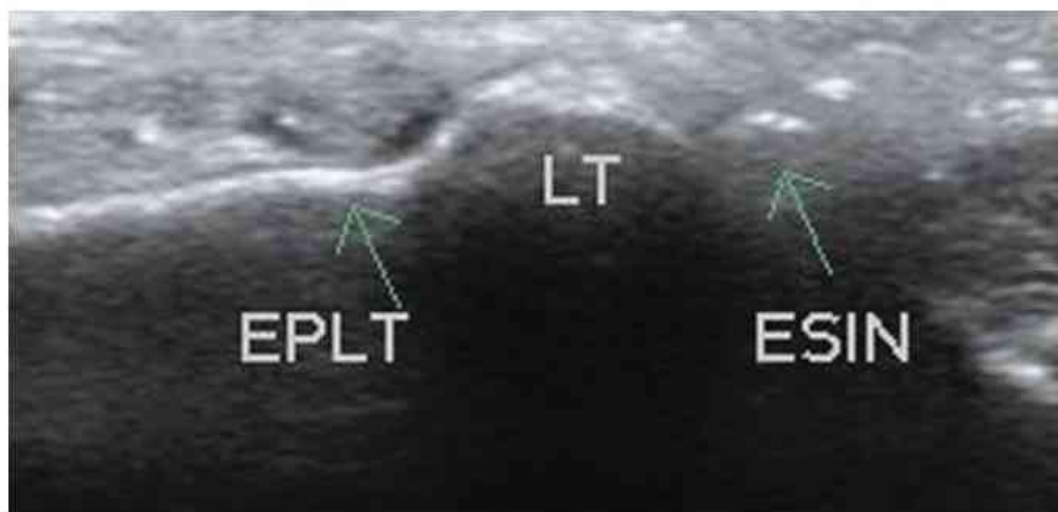

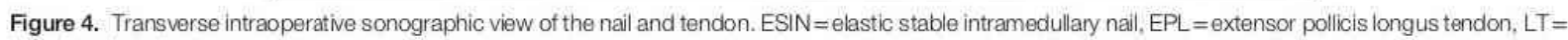
Lister's tubercule.

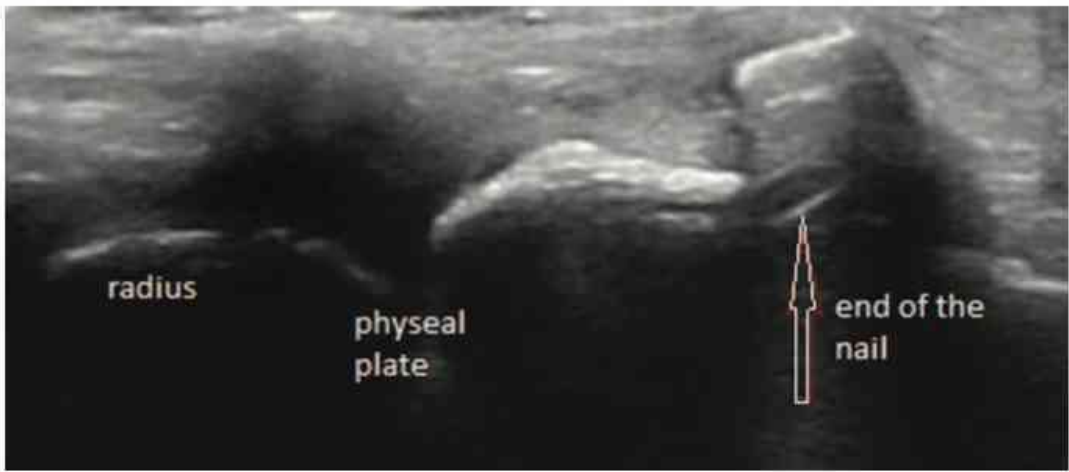

Figure 5. Longitudinal intraoperative sonographic view of the nail and the radius: Extensor pollicis longus tendon is not visualized.

In patients where we found that the nail was too close to the tendon or the EPL got stock during dynamic assessment), we corrected its position.

Procedures were executed by 2 orthopedic surgeons experienced in ESIN technique and with musculoskeletal ultrasonographic qualifications.

\section{Results}

Ultrasonographic identification of EPL and Lister's tubercle in the transverse view was possible in all children.

Determination of the position of the nail to EPL was also possible in all patients. Mean sonographically measured distance

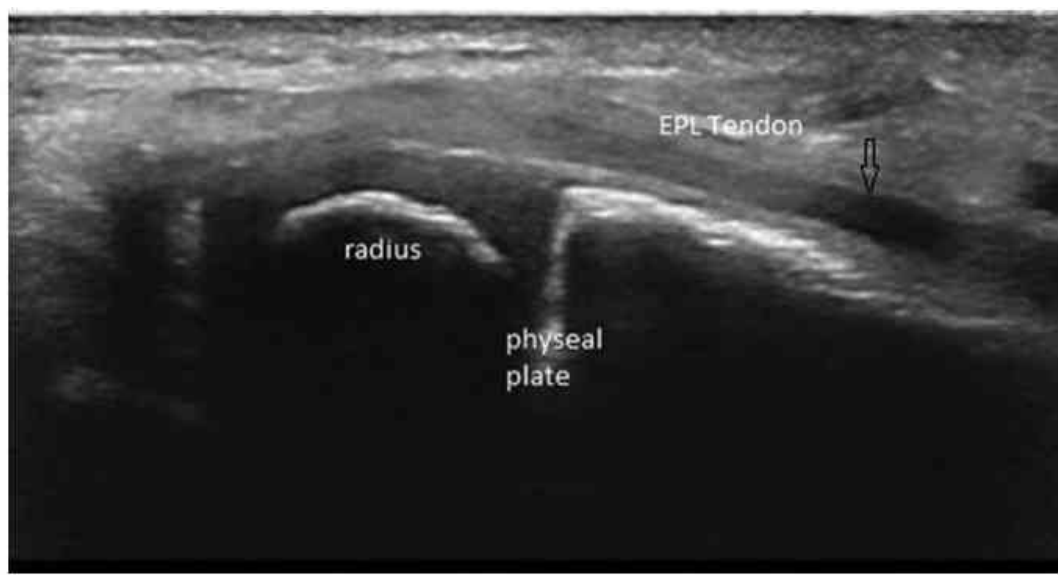

Figure 6. Longitudinal intraoperative sonographic view of the radius and the EPL tendon. Nail is not visualized in this plane. EPL=extensor pollicis longus. 


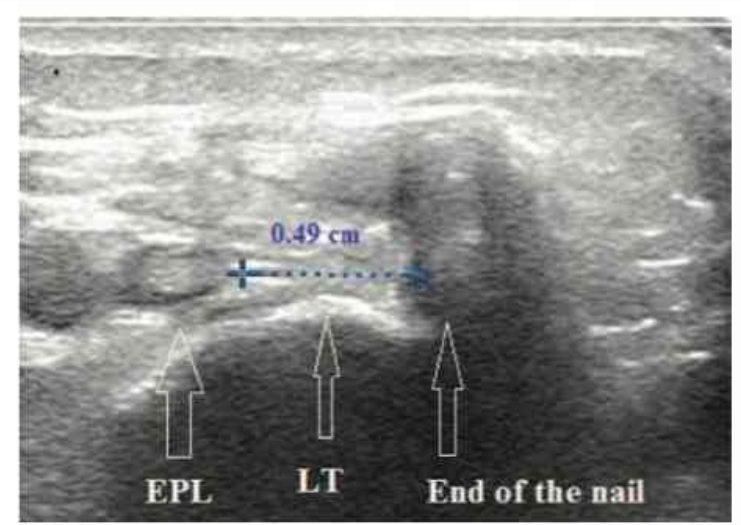

Figure 7. Measurement of the distance of the nail and the tendon in transverse sonographic view. $L T=L i s t e r ' s$ tubercule, $E P L=e x t e n s o r$ pollicis longus tendon.

of the transverse view center of the EPL and nail was $0.49 \mathrm{~cm}$ (range: $0.3-0.62 \mathrm{~cm}, \mathrm{SD}=0.66$ ) (Fig. 7).

Longitudinal view of EPL was not clearly defined in 2 cases.

Based on the sonographic transverse view (insertion points were 2 close $(<0.3 \mathrm{~cm})$ to EPL) the operator decided repositioning the nails by 2 patients.

On one occasion EPL movement was not seen with dynamic assessment, although the tendon was clearly identifiable. In this case, we decided re-bending the end of the nail. After correction, we were able to identify normal tendon movement.

Sonographic procedures took average 5 minutes (range: $2-8$ min. mean $=4.8 \mathrm{~min}$ ) extra time during operations.

We have not found EPL injury or septic complications postoperatively. All patients were followed for at least 12 months after operation. Nails were removed in all children without further complications.

\section{Discussion}

Among the muscles involved in thumb movement, the extensor pollicis longus (EPL) tendon of the hand is considered the most consistent structure with the least variation among individuals. ${ }^{[8]}$ Lister's tubercle is a prominent and sonographically easily visible landmark in the dorsal side of the radius. ${ }^{|9|}$

Intra-and postoperative usage of high-frequency ultrasound in musculoskeletal trauma is a relatively new method for various purposes. ${ }^{[10,11]}$ Recently, few authors have reported good initial results with sonography in different musculoskeletal operations. ${ }^{\lfloor 12,13\rfloor}$

Using sonography is advantageous due to the visualization of the relationship of various soft tissues (i.e. tendons, nerves, arteries) and implants which are invisible to $\mathrm{x}$-rays, and the lack of radiation. ${ }^{[10-13]}$ Ultrasound is also a reproducible tool for identification of EPL and its pathologies. ${ }^{[9]}$

The exact etiology of pediatric EPLT injury in forearm fractures is still a question of debate.

In adult populations direct injury, increased pressure in the third extensor compartment, poor vascularization, chronic mechanical irritation caused by an implant, callus formation or spontaneous idiopathic rupture may be considered as pathogenic factor theoretically. ${ }^{[14-17]}$ Although, there may be other causes, ${ }^{[18,19 \mid}$ since most of the pediatric EPL injuries found in the literature are related to dorsal entry elastic nailing, it seems to be a unique complication of the dorsal approach. ${ }^{[20-23]}$

A small cohort study identified no significant patient characteristics as any predictor of EPL rupture. ${ }^{[20]}$ In a study of 9 pediatric ruptures the nail entry site was directly related to the location of EPL. ${ }^{[5]}$ Direct injury of the tendon during insertion, or chronic irritation caused by the end of the nail can lead to tendon rupture. ${ }^{[23]}$

In a six years period in our institution (between 2010 and 2016) we have performed 354 dorsal entry radial nailing procedures and found 7 EPLT injuries retrospectively. Four cases were identified as acute (<one week after surgery) 3 as chronic (>one week postoperatively) injury. During reoperation, we found 6 complete ruptures. In all chronic and in one acute case extensor indicis tendon transfer has been performed. Direct repair was possible in 2 acute cases. In one case rupture of the EPL tendon was not confirmed intraoperatively: the tendon was mechanically obstructed by the nail, and this caused the block of motion. The reposition of the implant has solved the problem. We hypothesize that a late rupture would have occurred without our early intervention.

Cutting and bending the nail under the skin and above the level of the tendon helps to reduce the risk of skin irritation. ${ }^{\mid 24]}$ Reviewing the literature and our experiences we came to the conclusion that optimisation of the insertion point and the position of the extraosseal end of the nails can reduce the risk of both acute and chronic ruptures. Intraoperative ultrasound has been proven an easy and useful tool for visualizing these optimal reference points. We found that exact sonographic differentiation of Lister's eminence and transverse view of EPLT were easily feasible. The visualization of the end of the nail, and the determination of its position to Lister's eminence and tendon during insertion is more difficult and technically demanding. In spite of this latter fact using sonographic guidance took an average extra 5 minutes during operations. Two times the longitudinal views of tendons were not clearly identifiable. We think this was rather a technical problem in the early learning curve period.

Although the procedure seems very easy, the authors take note that surgical and sonoanatomic knowledge, sonographic skills, and experience in the ESIN technique are equally necessary for its successful application.

\section{Conclusion}

We came to the conclusion that intraoperative sonography may reduce the risk of the dorsal entry ESIN technique. The method is simple, harmless and only slightly increases the surgical time.

A greater number of cases is necessary to confirm our initial promising experiences.

\section{Author contributions}

Conceptualization: Marcell Varga, Sándor Pintér.

Data curation: Szilvia Papp.

Investigation: Marcell Varga, Nikoletta Gáti, Tamás Kassai, Szilvia Papp.

Methodology: Marcell Varga.

Project administration: Marcell Varga.

Resources: Marcell Varga.

Supervision: Sándor Pintér.

Writing - original draft: Marcell Varga.

Writing - review \& editing: Marcell Varga. 


\section{References}

[1] Schmittenbecher PP. State-of-the-art treatment of forearm shaft fractures. Injury 2005;36 (suppl 1):A25-34.

[2] Lascombes P, Haumont T, Journeau P. Use and abuse of flexible intramedullary nailing in children and adolescents. J Pediatr Orthop 2006;26:827-34.

[3] Hans-Georg Dietz, Perer P. Schmittenbecher, Theddy Slongo, et al. Elastic Stable Intramedullary Nailing ((ESIN) in Children AO Manual of Fracture Management. Davos: AO Publishing; 2006.

[4] Norgaard SL, Riber SS, Danielsson FB, et al. Surgical approach for elastic stable intramedullary nail in pediatric radius shaft fracture: a systematic review. J Pediatr Orthop B 2017;27:309-14.

[5] Brooker B, Harris PC, Donnan LT, et al. Rupture of the extensor pollicis longus tendon following dorsal entry flexible nailing of radial shaft fractures in children. J Child Orthop 2014;8:353-7.

[6] Murphy HA, Jain VV, Parikh SN, et al. Extensor tendon injury associated with dorsal entry flexible nailing of radial shafr fractures in children: a report of 5 new cases and review of the literature. J Pediatr Orthop 2016;DOI: 10.1097:BPO.0000000000000897. [Epub ahead of print].

[7] Lyman A, Wenger D, Landin L. Pediatric diaphyseal forearm fractures: epidemiology and treatment in an urban population during a 10-year period, with special attention to titanium elastic nailing and its complications. J Pediatr Orthop B 2016;25:439-46.

[8] Kim YJ, Lee JH, Baek JH. Variant course of extensor pollicis longus tendon in the second wrist extensor compartment. Surg Radiol Anat 2016;38:497-9.

[9] De Maeseneer M, Marcelis S, Osteaux M, et al. Sonography of a rupture of the tendon of the extensor pollicis longus muscle: initial clinical experience and correlation with findings at cadaveric dissection. AJR Am J Roentgenol 2005;184:175-9.

[10] Williams D, Singh J, Heidari N, et al. Assessment of penetration of dorsal screws after fixation of the distal radius using ultrasound: cadaveric study. Ann R Coll Surg Engl 2016;98:138-42.

[11] Owers KL, Grieve PP, Mee S, et al. Ultrasound changes in the extensor pollicis longus and flexor pollicis longus tendons following open reduction and internal fixation of displaced intra-articular fractures of the distal radius. J Hand Surg Eur Vol 2013;38:129-32.

[12] Watchmaker ID, Daley R.A, Watchmaker GP, et al. Ultrasound imaging improves identification of prominent hardware in the surgical treatment of distal radius fractures: a cadaveric and prospective clinical study. J Wrist Surg 2016;5:36-41.
[13] Soldado F, Knorr J, Haddad S, et al. Ultrasound-guided percutaneous medial pinning of pediatric supracondylar humeral fractures to avoid ulnar nerve injury. Arch Bone Jt Surg 2015;3:169-72.

[14] Hu CH, Fufa D, Hsu CC, et al. Revisiting spontaneous rupture of the extensor pollicis longus tendon: eight cases without identifiable predisposing factor. Hand (N Y) 2015;10:726-31.

[15] Lepage D, Tatu L, Loisel F, et al. Cadaver study of the topography of the musculotendinous junction of the finger extensor muscles: applicability to tendon rupture following closed wrist trauma. Surg Radiol Anat 2015;37:853-8.

[16] Engkvist O, Lundborg G. Rupture of the extensor pollicis longus tendon after fracture of the lower end of the radius-a clinical and microangiographic study. Hand 1979;11:76-86.

[17] Lee SK, Bae KW, Choy WS, Use of the radial groove view intraoperatively to prevent damage to the extensor pollicis longus tendon by protruding screws during volar plating of a distal radial fracture. Bone Joint J 2013;95-B:1372-6.

[18] Song D, Evans R, Arneja JS. Delayed extensor pollicis longus tendon rupture following nondisplaced distal radius fracture in a child. Hand $(\mathrm{N}$ Y) $2013 ; 8: 242-4$

[19] Mansour AA, Watson JT, Martus JE. Displaced dorsal metaphyseal cortex associated with delayed extensor pollicis longus tendon entrapment in a pediatric Smith's fracture. J Surg Orthop Adv 2013;22:173-5.

[20] Lee AK, Beck JD, Mirenda WM, et al. Incidence and risk factors for extensor pollicis longus rupture in elastic stable intramedullary nailing of pediatric forearm shaft fractures. I Pediatr Orthop 2016;36:810-5

[21] Kay RM, Khounganian GS, Stevanovic M. Late extensor pollicis longus rupture following displaced distal radius and ulna fractures in a child. J Orthop Trauma 2004;18:53-6.

[22] Kruppa C, Bunge P, Schildhauer TA, et al. Low complication rate of elastic stable intramedullary nailing (ESIN) of pediatric forearm fractures: a retrospective study of 202 cases. Medicine (Baltimore) 2017:96:e6669.

[23] Stahl S, Calif E, Eidelman M. Delayed rupture of the extensor pollicis longus tendon following intramedullary nailing of a radial fracture in a child. J Hand Surg Eur Vol 2007;32:67-8.

[24] Gibbon E, Beranger JS, Bachy M, et al. Influence of the bending of the tip of elastic stable intramedullary nails on removal and associated complications in pediatric both bone forearm fractures: a pilot study. Int J Surg 2015;16:19-22. 


\title{
Gyermekkori csuklótáji törések diagnosztikája ultrahanggal
}

\author{
Varga Marcell dr. ${ }^{1}$ - Gáti Nikolett dr. ${ }^{1}$ - Kalóz Erika dr. ${ }^{1}$ \\ Bíró Zsuzsanna dr. ${ }^{1}$. Szeverényi Csenge dr. ${ }^{2}$ \\ Kardos Dániel dr. ${ }^{3}$ " Józsa Gergó dr. ${ }^{3}$ \\ Péterfy Sándor Utcai Kórház-Rendelőintézet, Baleseti Központ, Gyermektraumatológiai Osztály, Budapest \\ ${ }^{2}$ Debreceni Egyetem, Általános Orvostudományi Kar, Klinikai Központ, Ortopédiai Klinika, Debrecen \\ ${ }^{3}$ Pécsi Tudományegyetem, Általános Orvostudományi Kar, Gyermekgyógyászati Klinika, Manuális Tanszék, \\ Sebészeti Osztály, Pécs
}

\begin{abstract}
Bevezetés és célkitîzés: Prospektív tanulmányunk célja a gyermekkori csuklótörések ultrahang-diagnosztikájának ismertetése és két mozgásszervi centrum eredményének bemutatása.

Módszer: 2011 januárja és 2015 decembere között 467, 1-15 év közötti gyermek ultrahangvizsgálatát végeztük el. Valamennyi gyermek zárt sérülést szenvedett el és nyitott epiphysisfugával rendelkezett. Az ultrahangvizsgálatot rezidensek és ortopéd-traumatológus, illetve gyermeksebész szakorvosok végezték közvetlenül az elsốdleges fizikális vizsgálatot követően, $7-14 \mathrm{MHz}$ frekvenciatartományú lineáris transzducerekkel. Az eredményeket hagyományos kétirányú csukló-röntgenfelvételekkel hasonlitottuk össze.

Eredmények: 97\%-os szenzitivitást és 96\%-os specificitást találtunk. Elmozdulással és komolyabb klinikai konzekvenciával járó törések ultrahanggal is mind felismerésre kerültek.

Következtetés: A mozgásszervi ultrahangvizsgálat a gyermekkori csuklótáji törések igazolásának vagy kizárásának rendkívül hatékony eszköze a napi gyakorlatban.
\end{abstract}

Orv Hetil. 2017; 158(24): 944-948.

Kulcsszavak: ultrahang, gyermekkor, csuklótörés

\section{Ultrasonographic diagnosis of distal pediatric forearm fractures}

Introduction and aim: The aim of our prospective study was to evaluate the effectivity of sonographic diagnosis of pediatric wrist fractures and analyzing the results of two pediatric musculoskeletal centers.

Method: Between 2011 January and 2015 December 467 children aged 0-15 with closed wrist injuries and open growth plates were sonographically and radiologically evaluated by an orthopaedic surgeon or a resident in trainee. Sonography was performed immediately after physical examination with linear probes of 7-14 Mhz frequency. Results were compared to conventional two plane wrist $x$-rays.

Results: We found 97 sensitivity and 96 specificity of the sonographic evaluation. Fractures with dislocations and more serious clinical consequences were never missed.

Conclusion: Musculoskeletal ultrasound is a very effective tool in daily routine for diagnosing or excluding pediatric wrist fractures.

Keywords: sonography, pediatric, wrist fracture

Varga M, Gáti N, Kalóz E, Bíró Zs, Szeverényi Cs, Kardos D, Józsa G. [Ultrasonographic diagnosis of distal pediatric forearm fractures]. Orv Hetil. 2017; 158(24): 944-948.

(Beérkezett: 2017. március 21,; elfogadva: 2017. április 13.) 
A csuklótáji törések világszerte a gyermekkor leggyakoribb sérülései közé tartoznak, illetve növekvó tendenciát mutatnak [1-4].

A Péterfy Sándor Utcai Kórház-Rendelóintézet és Baleseti Központ Gyermekambulanciáján évente mintegy 1500 gyermek ambuláns vizsgálata történik csuklótáji sérülés miatt. A pontos diagnózis felállítása az esetek túlnyomó részében röntgen- (RTG-) képalkotással történik $[4,5]$. A hagyományos kétirányú RTG-felvétel elhanyagolható egészségügyi kockázatot jelent, ugyanakkor világszerte hangsúlyozott törekvés az ionizáló sugárzás lehetôség szerinti minimalizálása $[6,7]$.

Az utóbbi években számos közlemény jelent meg a gyermekkori csuklótáji törések „point of care" ultrahangos (UH-) diagnosztikájáról [8-12]. A legtöbb szerző egyetért abban, hogy a módszerrel nemcsak a törés ténye, hanem konfigurációja és elmozdulásának mértéke is a RTG-vizsgálatokkal lényegében egyezó effektivitással értékelhetổ [13].

Magyarországon - tudomásunk szerint - gyermekkori törésdiagnosztika céljából ultrahangot rutinszerüen, elfogadott protokoll szerint sehol nem alkalmaznak, illetve magyar nyelvú beszámoló ilyen irányú alkalmazásról eddig nem jelent meg.

A Péterfy Sándor Utcai Kórház-Rendelóintézet és Baleseti Központ Gyermektraumatológiai Osztályán 2011, a Pécsi Tudományegyetem Gyermeksebészeti Centrumában 2014 óta végzünk gyermekkori ultrahangos törésdiagnosztikát.

Prospektív tanulmányunk célja a módszer ismertetése és a két mozgásszervi centrum eredményének bemutatása.

\section{Betegek és módszer}

Vizsgálatunk során a gyermekeket - az ambulanciára való beérkezésüket követően, a primer fizikális vizsgálattal egy idốben - lineáris fejjel ellátott ultrahangkészülékkel is megvizsgáltuk. A vizsgálatok során összesen három különbözổ típusú ultrahangkészüléket használtunk. A lineáris fejek frekvenciatartománya 7-14 MHz-ig terjedt.

A két gyermektraumatológiai centrumban 2011. december és 2015. december között 467 dokumentált esetben végeztünk $\mathrm{UH}$-diagnosztikát. A vizsgálatokat a két intézetben összesen hat orvos végezte (két ortopédtraumatológus szakorvos, két ortopéd-traumatológus szakorvosjelölt, egy gyermeksebész szakorvos, valamint egy gyermeksebész rezidens) „point of care" módon, azaz közvetlenül a fizikális vizsgálatot követöen, a RTGfelvételek elkészülése elött.

A vizsgálatba csak olyan gyermekeket vontunk be, akiknél a fizikális vizsgálat és a klinikum alapján kizárólag kétirányú csuklófelvétel indikációja állt fenn. Kizárólag nyitott növekedési porcok mellett értékeltük az eredményeket. Kizártuk a vizs gálatból azokat az eseteket, ahol a fájdalom nem pontos lokalizációja, a kooperáció hiánya vagy az anamnézis alapján egyéb testtájék RTG-vizsgálata is szükségessé vált (os scaphoideum törése miatt négyirányú felvétel, alkartörés gyanúja miatt alkar-RTG-felvétel stb.).

A vizsgálat háton fekve vagy ülö pozícióban történt. Az érintett végtagot a gyermek hasára vagy az előtte lévő vizsgálóasztalra helyeztük (1. és 2. ábra).

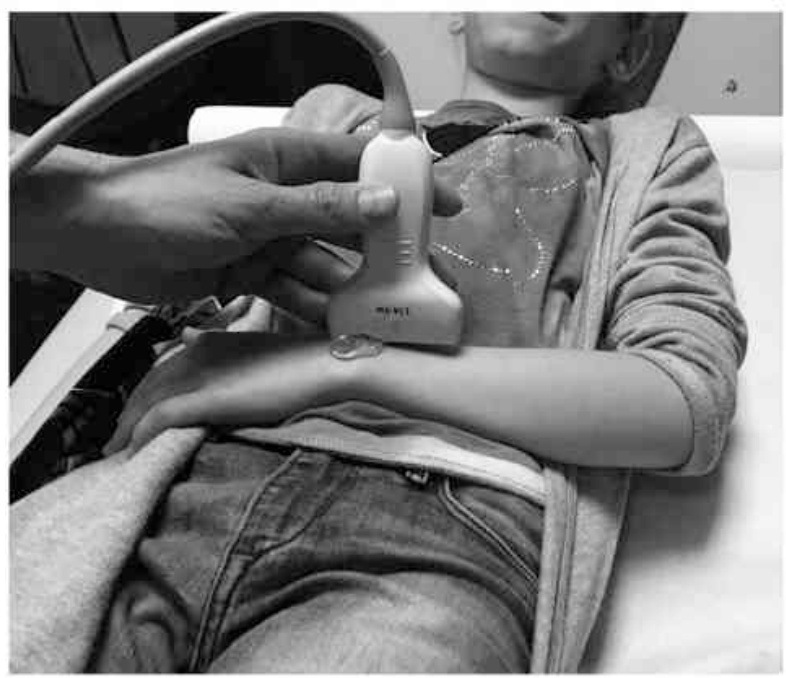

1. ábra | Háton fekvổ gyermek csuklósćrülésénck vizsgálata ultrahanggal

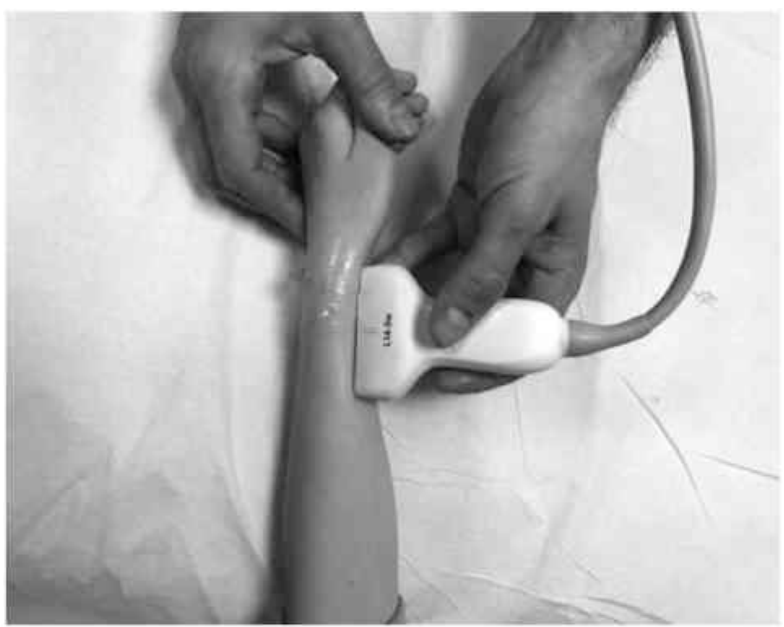

2. ábra

| Transzducertartás ventralis radialis sikban

A transzducerrel hat különbözô, a végtag tengelyével megegyező, longitudinális síkban jártuk körül a csuklót, így egy dorsoulnaris, dorsoradialis, lateroradialis, medioulnaris és két ventralis leképezést nyertünk (3. ábra).

Az ellátás ezután a hagyományos protokoll szerint (kétirányú csukló-röntgenfelvétel) folytatódott.

Az ultrahang- és fizikális vizsgálat által felállított diagnózis pontosságát a RTG-felvételekkel összevetve értékeltük (4. és 5. ábra). 


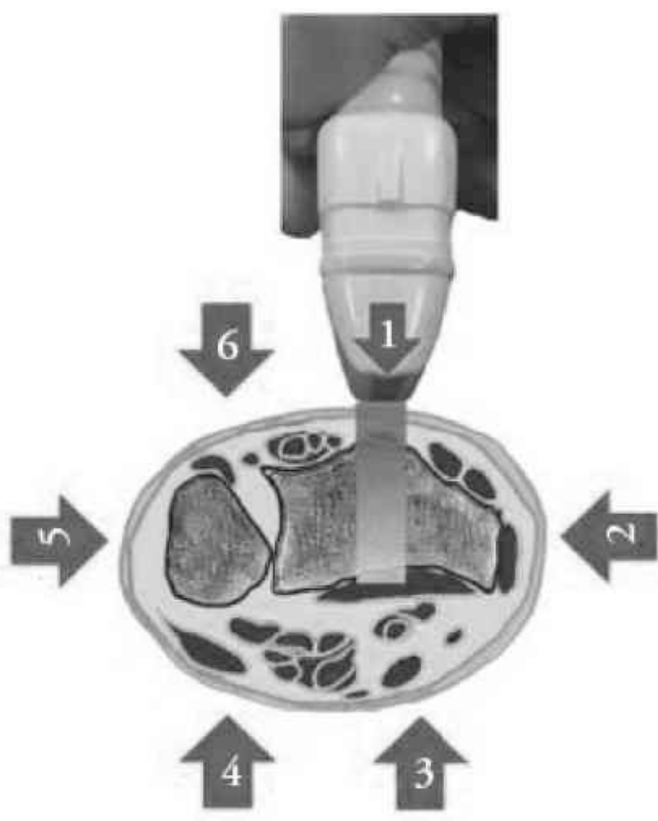

3. ábra |A transzducer által leképzetr síkok sémás ábrája

A vizsgálatok eredményeinek pontos feldolgozásához egy értékelólapot szerkesztettünk. A lapon a vizsgáló személy - a beteg adatainak kitöltése után - a primer vizsgálatot követốen bejelölte, hogy a klinikum és az ultrahangvizsgálat alapján véleményez-e törést, ha igen, milyen jellegünek ítélte meg azt. A RTG-felvétel elkészültét követően felvezetésre került a klinikus által a röntgen alapján véleményezett diagnózis. A radiológus által kiadott lelet szintén felvezetésre került, így a vizsgálati eredményeket objektíven tudtuk összehasonlítani.

A fenti kritériumoknak megfelelóen 467 esetet értékeltünk.

\section{Eredmények}

$270(57,8 \%)$ esetet a primer RTG alapján pozitívnak, 197-et $(42,2 \%)$ negatívnak találtunk. Ultrahangvizsgálattal 263 esetet értékeltünk pozitívnak és 204-et negatívnak (1. táblázat).

\begin{tabular}{l|l} 
1. táblázat & $\begin{array}{l}\text { A RTG- és UH-vizsgálattal értékelt pozitiv és negatív esctek } \\
\text { megoszlása (n }-467)\end{array}$
\end{tabular}

\begin{tabular}{lcl}
\hline & RTG & UH \\
\hline Pozitiv & 270 & 263 \\
Negativ & 197 & 204 \\
\hline
\end{tabular}

Az észlelt töréseket a klinikai konzekvenciát illetően (konzervatív kezelés, repozíciós igény, mütéti igény) három csoportba osztottuk. Az álnegatív és álpozitív esetek megoszlását az egyes csoportokon belül is vizsgáltuk (2. táblázat).
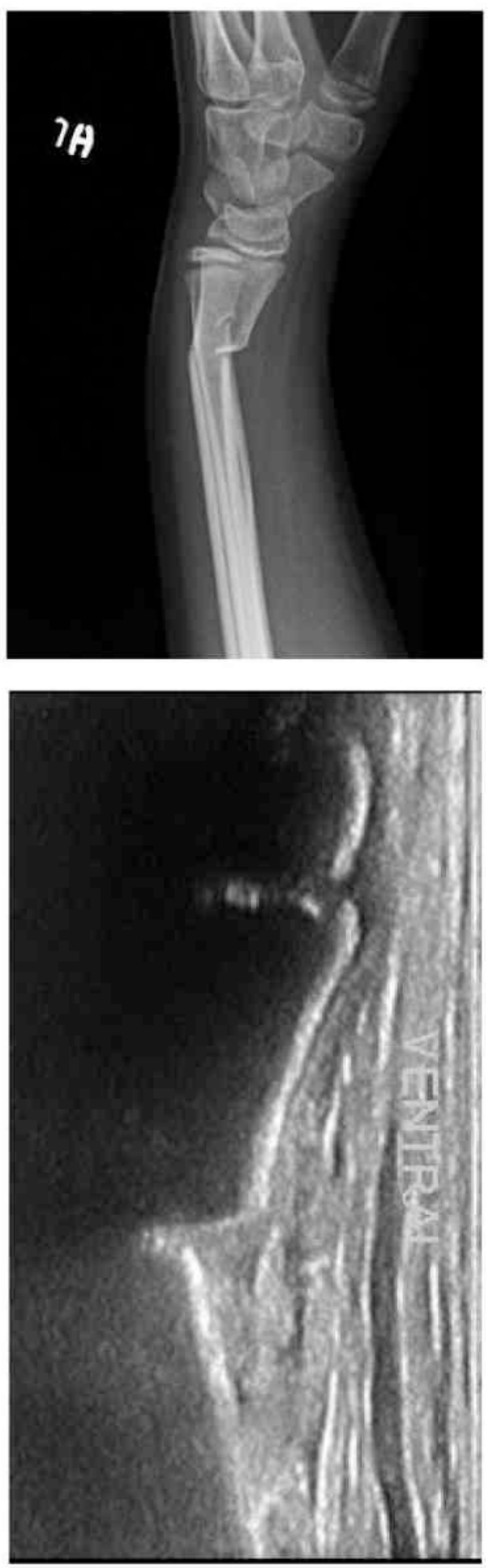

4. és 5. ábra | OIdalirányú csukló-RTG- ćs ennek mcgfclcló UH-felvétel

Az álnegatív eseteket, amikor ultrahanggal nem sikerült a RTG-felvételeken látható törést igazolni $(n=7)$, az elmozdulás nélküli, klinikai konzekvenciával nem járó csoportokban észleltük. Álpozitív eredményeket, amikor az ultrahanggal törésnek véleményezett törés RTG-fel- 
2. táblázat |Az álpozitiv és álncgativ ultrahangos esctek megoszlása az cgyes klinikai csoportokon bclül

\begin{tabular}{|c|c|c|c|}
\hline $\begin{array}{l}\text { Az észlelt törések felosztása klinikai } \\
\text { konzekvencia alapjân, } \mathrm{n}=270\end{array}$ & $\begin{array}{l}\text { RTG } \\
\text { pozitiv }\end{array}$ & $\begin{array}{l}\text { UH } \\
\text { âlnegativ }\end{array}$ & $\begin{array}{l}\text { UH } \\
\text { álpozitiv }\end{array}$ \\
\hline $\begin{array}{l}\text { Csckély klinikai konzckvenciával } \\
\text { járó esetek, átmeneti rögzítést, } \\
\text { fäjdalomesillapítást, gipszet vagy } \\
\text { rögzítố brace-t igénylö } \\
\text { torustörésck és elmozdulás nélküli } \\
\text { metaphysistörések }\end{array}$ & $\begin{array}{l}\mathrm{n}=188 \\
(70 \%)\end{array}$ & $\mathrm{n}=7$ & $\mathrm{n}=7$ \\
\hline $\begin{array}{l}\text { Helyi érzéstelenítésben vagy } \\
\text { narkózisban való helyretételt, } \\
\text { gipszrögzítést igénylố } \\
\text { szöglettöréssel járó } \\
\text { metaphysistörések a csontcorticalis } \\
\text { folytonosságával }\end{array}$ & $\begin{array}{l}\mathrm{n}=52 \\
(20 \%)\end{array}$ & 0 & 0 \\
\hline $\begin{array}{l}\text { Mütéti ellátást igénylö, } \\
\text { a periosteum-szakadással járó nagy } \\
\text { fokban elmozdult törések }\end{array}$ & $\begin{array}{l}\mathrm{n}=30 \\
(11 \%)\end{array}$ & 0 & 0 \\
\hline
\end{tabular}

vételen nem igazolódott $(\mathrm{n}=7)$, szintén csak ebben a csoportban találtunk. A fentiek alapján a szenzitivitást 97\%-nak, a specificitást 96\%-nak találtuk.

Három, primeren álpozitív esetben a nem szünó fájdalmak miatt késóbb végzett ismételt RTG-vizsgálat callusképzôdést igazolt, emiatt ezeket utólag pozitívnak minősítettük.

A diagnosztikát végző személyek hatékonysága között szignifikáns különbséget nem találtunk. A RTG-és UHvizsgálattal észlelt 14 ellentmondó diagnózist a tanulási fázis elején, az elsố 100 eset során állították fel.

\section{Megbeszélés}

A gyermekkori csuklótáji törések diagnózisát, illetve a további terápiás terv felállítását hagyományosan RTG alapján végezzük. A RTG-vizsgálattal igazolható a törés, epiphyseolysis ténye, tengelyeltérésének mértéke [14, 15]. További terápiás tervet a gyermek korának, az elmozdulás mértékének figyelembevételével állítjuk fel.

Gyermekkori ultrahangos törésdiagnosztikát rutinszerû́en kevés helyen végeznek a világon. Ennek szervezési, szakmai és anyagi okai is lehetnek - a gyermeksérültek elsódleges ellátása világszerte más-más rendszer alapján történik. A sürgôsségi osztályok személyi és tárgyi felszereltsége is jelentốs különbséget mutat $[16,17]$.

A sikeres diagnosztikához gyermektraumatológiában és musculoskeletalis szonográfíban is jártas szakember szükséges. A módszer előnyei ugyanakkor egyértelműek. Gyors, a beteg számára fájdalmatlan, noninvazív és talán a legfontosabb, hogy ionizáló sugárzással nem jár [8-13, $17,18]$.

Vizsgálataink és a nemzetközi irodalom alapján ultrahanggal a terápiás konzekvenciával járó törések jelenléte, illetve hiánya egyértelmúen detektálható és a RTG-nel csaknem megegyező objektív információ nyerhető [8$13,19]$.

Az ultrahangos törésvizsgálat lehetósé gét a régió gyermekkori sajátosságai teremtik meg. Tizennégy éves kor alatt, illetve nyitott növekedési porcok mellett a felnóttkorra jellemzó ízületi lépcsóképzódéssel járó, illetve öszszetett darabos distalis radiustörések nagyon ritkák. A típusos gyermekkori csuklótáji törések (epiphyseolysisek, metaphysis-, torustörések stb.) konfigurációja jellegzetes, a csontcorticalis megváltozásának típusos képével jár.

\section{A vizsgálati technikáról}

A lineáris transzducer által kibocsátott, a csontról teljes egészében visszaverōdő ultrahangnyalábok által képzett rajzolat, az adott sík csontcorticalis vonalát a röntgenhez hasonlóan jeleníti meg. Különbség, hogy míg a RTGfelvételen szummációs képet látunk, az UH által alkotott kép mindig a transzducer vastagságának megfelelő területrôl mutat egy szeletet. Ezért fontos, hogy a vizsgálófejet mindig merôlegesen, billentés nélkül helyezzük a csontok hossztengelyére, hogy a képalkotás pontos legyen. A klinikai gyakorlatban a hat standard sík alkalmazása (radiodorsalis, ulnodorsalis, ulnoulnaris, radioradialis, radiopalmaris és ulnopalmaris) elegendő, bár elméletben a csuklót a transzducerrel körbejárva korlátlan számú szelet leképezhetô. További különbség, hogy a dorsalis, illetve palmaris irányból felhelyezett transzducer az oldalirányból készült, az ulnaris, illetve radialis irányból képzett szonográfiával pedig az ap. RTG-felvétellel nyerünk analógiába vonható képet (2. ábra). A vizsgálat során a gyermekek karját csak minimálisan kell mobilizálni, ez az alkar és a csukló egyidejü rögzítésével minden esetben probléma nélkül kivitelezhetô.

Vizsgálatainkban "hagyományos”, alacsonyabb felbontású fejet $(7 \mathrm{MHz})$ és "high resolution”, magas felbontású transzducert $(14 \mathrm{MHz})$ is használtunk. Bár a magas felbontású fejekkel értelemszerúen részletgazdagabb kép nyerhetô, a distalis radius- és ulnatörések diagnosztikai hatékonyságának tekintetében nem találtunk különbséget a gépek között. A nagy elmozdulással, teljes periosteum-átszakadással járó, általában operatív indikációt jelentő esetek ultrahangos pontos értékelése nehezebb, ilyenkor a szonográfiás kép alapján a törés ugyan egyértelmủen megállapítható, de annak pontos konfigurációjára nehéz következtetni. Ugyanakkor tapasztalataink azt mutatják, hogy a megfelelő gyakorlat megszerzését követốn a diagnosztikai hatékonyság is növekszik.

A tévesen felállított diagnózisoknak (álpozitív, illetve álnegatív esetek) a terápiára kiható érdemi konzekvenciája elméletileg nincs, mivel gyakorlatunk alapján a végtag rögzítése (gipszsín, brace) még töréssel nem járó csuklóés alkarsérülések esetében is indokolt a gyermek panaszai függvényében, és kontrollvizsgálattal az ilyen esetek kiszürhetőek.

Érdemi terápiát igénylő, elmozdulással járó esetek vizsgálata során nem találtunk különbséget az ultrahang- 
és a röntgendiagnosztika hatékonysága közt. Az eltérő diagnózisok az elsố 100 esetszám során születtek, így az eljárás „tanulási görbéjének” szerepe sem elhanyagolható.

Figyelemre méltó, hogy három betegnél az ultrahangvizs gálattal a klinikus törést diagnosztizált, míg a primer röntgen negatívnak bizonyult. Mivel ezeknek a gyermekeknek elhúzódó panaszai voltak, ismételt RTG-vizsgálatot végeztünk. A négy héttel később készült RTGfelvételen periostealis callus ábrázolódott, amely egyértelmúen korábban lezajlott okkult törésre utal. Ezek alapján feltételezhető, hogy bizonyos esetekben az ultrahang- a röntgenvizsgálatnál szenzitívebb is lehet.

Elvileg differenciáldiagnosztikai problémát jelenthetnek a patológiás (például juvenilis ciszta) alapon kialakuló törések. Bár a vizsgált betegek között ilyen jellegú elváltozás nem fordult elő, feltételezzük, hogy a csontcorticalis felfújt szerkezetének, illetve az esetleges lágyrész-folyamat jelenlétének egyértelműen fel kell hívnia a figyelmet a további képalkotás (CT, MRI stb.) szükségességére.

\section{Következtetés}

Megfeleló helyi, tárgyi és személyi feltételek megléte esetén (rendelkezésre álló UH-készülék, amelynek segítségével a vizsgálat a primer fizikális vizsgálattal egy időben és egy helyen elvégezhetô, gyermektraumatológiai ellátásban jártas szakember mozgásszervi ultrahangkezelési ismeretekkel) a fenti módszer segítségével az ellátás gyorsasága és hatékonysága jelentősen növelhető. Az irodalomban fellelhetô tanulmányok hasonló eredményekről számolnak be, ugyanakkor nagy esetszámú fẹldolgozást keveset találtunk [13].

Hangsúlyozni szeretnénk, hogy tanulmányunkkal nem azt szándékoztuk sugallni, hogy a gyermekkori csuklótörések cllátásában a RTG-vizsgálat felesleges, hanem azt, hogy tapasztalataink alapján az UH-vizsgálat nagyon effektív, hasznos kiegészítôje lehet a napi ambuláns ellátásnak, illetve bizonyos feltételek teljesülése esetén a röntgenvizsgálat alternatívája is lehet.

A diagnosztikai módszer esetleges önálló alkalmazása, illetve kiterjesztése ugyanakkor számos jogi és gyakorlati kérdést is felvet (mikor, milyen dokumentácó szükséges az objektív értékeléshez, milyen képesítéssel lehetne végezni stb.), amelyek megválaszolása, illetve a megfelelő protokollok kidolgozása még várat magára. A szerzők további prospektív vizsgálatokat terveznek ezek eldöntésére.

Anyagi támogatás: A kézirat megírása anyagi támogatásban nem részesült.

Szerzôi munkamegosztós: V. M.: A hipotézis kidolgozása, a vizsgálat lefolytatása, a kézirat elkészítése. J. G.: A vizsgálat lefolytatása, a kézirat elkészítése. B. Zs., K. E.,
G. N., K. D.: A vizsgálat lefolytatása. A cikk végleges változatát valamennyi szerző elolvasta és jóváhagyta.

Érdekeltségek: A szerzóknek nincsenek érdekeltségeik.

\section{Irodalom}

[1] Naranje SM, Erali RA, Warner, WC Jr, et al. Epidemiology of pediatric fractures presenting to emergency departments in the United States. J Pediatr Orthop. 2016; 36: c45-c48.

[2] Shah NS, Buzas D, Zinberg EM. Epidemiologic dynamics contributing to pediatric wrist fractures in the United States. Hand (NY) $2015 ; 10: 266-271$.

[3] de Putter CE, van Beeck EF, Looman CW, et al. Trends in wrist fractures in children and adolescents, 1997-2009. J Hand Surg Am. 2011; 36: 1810-1815.e2

[4] Gornitzky AL, Milby AH, Gunderson MA, et al. Referral patterns of emergent pediatric hand injury transfers to a ter tiary carc center. Orthopedies 2016; 39: e333-c339.

[5] Slaar A, Walenkamp MM, Bentohami A, et al. A clinical decision rule for the use of plain radiography in children after acute wrist injury: development and external validation of the Amsterdam Pediatric Wrist Rules. Pediatr Radiol. 2016; 46: 50-60.

[6] Herren C, Sobottke R, Ringe MJ, et al. Ultrasound-guided diagnosis of fractures of the distal forcarm in children. Orthop Traumatol Surg Res. 2015; 101: 501-505.

[7] Little JT, Klionsky NB, Chaturvedi A, et al. Pediatric distal forearm and wrist injury: an imaging review. Radiographics 2014; 34: $472-490$.

[8] Dubrovsky AS, Kempinska A, Bank I, et al. Accuracy of ultrasonography for determining suceessful realignment of pediatric forearm fractures. Ann Emerg Med. 2015; 65: 260-265.

[9] Eckert K, Ackermann O. Sonographic fracture diagnosis in children. Unfallchirurg. 2014; 117; 355-368.

[10] Chaar-Alvarez FM, Warkentine F, Cross K, et al. Bedside ultrasound diagnosis of nonangulated distal forearm fractures in the pediatric emergency department. Pediatr Emerg Care 2011; 27: $1027-1032$

[11] Patel DD, Blumberg, SM, Crain, EF. The utility of bedside ultrasonography in identifying fractures and guiding fracture reduction in children. Pediatr Emerg Care 2009; 25: 221-225.

[12] Williamson D, Watura R, Cobby M. Ultrasound imaging of forearm fractures in children: a viable alternative? J Accid Emerg Med. 2000; 17: 2224 .

[13] Chartier LB, Bosco L, Lapointe-Shaw L. Use of point-of-care ultrasound in long bone fractures: a systematic review and metaanalysis. CJEM 2017; 19:131-142.

[14] Ruffing T, Danko T, Henzler T, et al. Number of positive radiographic findings in pediatric trauma patients. Emerg Radiol. 2017 Jan 26. doi: 10.1007/s10140-017-1482-x. [Epub ahead of print]

[15] Chia B, Kozin SH, Herman, MJ, et al. Complications of pediatric distal radius and forearm fractures. Instr Course Lect. 2015; 64: 499-507.

[16] Matheny JM, Brinker MR, Elliott MN, et al. Confidence of graduating family practice residents in their management of musculoskcletal conditions. Am J Orthop. 2000; 29: 945-952.

[17] Wellsh BM, Kuzma JM. Ultrasound-guided pediatric forcarm fracture reductions in a resource-limited ED. Am J Emerg Med. 2016, 34: 40-44.

[18] Ng L, Saul T, Lewiss RE. Sonographic baseline physeal plate width measurements in healthy, uninjured children. Pediatr Encrg Care 2014; 30: 871-874.

[19] Wong CE, Ang AS, $\mathrm{Ng}$ KC. Ultrasound as an aid for reduction of paediatric forearm fractures. Int J Emerg Med. 2008; $1: 267-$ 271.

(Varga Marcell dr., e-mail: drvmarcell@gmail.com) 


\title{
Gyermekkori csonttörések vizsgálata ultrahanggal
}

\author{
DR. VARGA MARCELL', DR. TÓTH LUCA1, DR. GARANCSY GLÓRIA², \\ DR. RIBES KITT12, DR. PINTÉR SANDOR ${ }^{2}$
}

\section{ÖSSZEFOGLALÁS}

Bár az ultrahanggal végzett törésdiagnosztika lehetôsége évtizedek óta ismert, a módszer mégsem terjedt el rutinszerüen. A magas frekvenciájú transzducerek, illetve nagy felbontású készülékek elterjedésével, továbbá a klinikusok által végzett „point of care” vizsgálatok egyre népszerủbbé válásával a szonográfiás törésdiagnosztika ismét az érdeklődés középpontjába került. Gyermekkorban szerepe felértékelốdik, mert csökkentheti a felesleges röntgenvizsgálatok számát, illetve gyorsíthatja az akut ellátást. A kedvezó tapasztalatok és az egyre növekvố számú tanulmány ellenére ugyanakkor a mai napig nem állnak rendelkezésünkre magas szintû evidenciák. Cikkünkben összefoglaljuk az akut gyermektraumatológiai ellátás során alkalmazható ultrahangos törésdiagnosztikai lehetőségeket, ezek előnyeit és potenciális klinikai alkalmazásukat. A szerzők megjegyzik, hogy a bemutatott módszerek kiegészitó lehetôségek, céljuk nem a röntgenvizsgálatok teljes helyettesítése, hanem a diagnosztikus hatékonyság növelése, biztonságosabbá tétele, valamint a felesleges sugárexpozíció csökkentése.

\section{Kulcsszavak: Diagnosztika; Gyermekkor; Radiográfia; Törések; Ultrahang;}

M. Varga, L. Tóth, G. Garancsy, K. Ribes, S. Pintér: Ultrasound diagnostics of fractures in children

Although ultrasound diagnostics of bone fractures has been known for decades, the method has not spread widely. With the development of high-frequency and high-resolution devices, as well as the growing popularity of point-of-care examinations by clinicians, sonographic fracture diagnostics have once again become the focus of interest. It is particularly important in childhood, by reducing the number of unnecessary $x$-ray examinations and speeding up acute care. Despite the positive experiences and the increasing number of studies, we still have no high-level evidence to date. In our article, we summarize the ultrasonic diagnostic options for paediatric bone fractures, their benefits and their potential clinical application. The authors note that the methods presented are complementary and not intended to replace $\mathrm{X}$-ray examinations, but to increase diagnostic efficacy, make it safer and reduce unnecessary radiation exposure.

Keywords:

Child; Fractures, bone - Diagnostic imaging; Point-of-Care Systems;

Radiography; Ultrasonography - Methods; 


\section{BEVEZETÉS}

A magas frekvenciájú transzducerekkel végzett mozgásszervi ultrahang diagnosztika az elmúlt években jelentős fejlódésen esett át, és egyre általánosabbá vált használata az akut ellátás során is $(8,9)$. A nemzetközi irodalom az ultrahang ilyen iranyú alkalmazását sokszor a „point of care” jelzővel illeti (22). A fenti kifejezést magyarra fordítani nehéz, de általánosságban olyan, klinikus által végzett ultrahangos gyorsdiagnosztikát jelent, ami célzott klinikai kérdésre keresi a választ. Intézetünkben 2011 óta alkalmazunk klinikus által végzett akut mozgásszervi ultrahang diagnosztikát a gyermektraumatológiai ellátás során.

A csonttörések szonográfiás diagnosztikai lehetőségéröl Leitgeb számolt be először 1986-ban (31). Magyarországon Farbaky Zsófia és munkatársai írtak elöször a csonttörések szonográfiás vizsgálatáról (20). Bár azóta számos tanulmány született, amely az egyes testtájékok ultrahangos törésdiagnosztikájának effektivitását igazolta, a módszer nem terjedt el rutinszerüen $(7,10,12,25,41,45)$. Ennek több oka is lehet. Egyrészt az ultrahang diagnosztika nem alkalmazható valamennyi töréstípusnál egységesen, másrészt speciális jártasságot, szervezést igényel használata az akut ellátás során $(7,10,12,25)$. A magas frekvenciájú, nagy felbontású készülékek klinikai gyakorlatban való elterjedésének köszönhetően ugyanakkor a közelmúltban ismét az érdeklődés középpontjába került (11).

A legtöbb tanulmányt angolszász rendszerú sürgősségi osztályok végezték, a szonográfiás törésdiagnosztikát itt általában az ellátást gyorsító triage, illetve további képalkotás igénybevételének eldöntéséhez való szúrés céljából alkalmazzák (11). További kutatások igazolták az ultrahang törések észlelésében való diagnosztikus elönyeit harctéri övezetekben, illetve forrásaiban korlátozott egészségügyi ellátó helyeken $(7,12,11)$. Az ultrahang ugyanakkor egyéb kiegészítő képalkotást szükségtelenné tevő definitiv diagnosztikaként is használható, föleg bizonyos gyermekkori töréstípusok esetén. Ilyen irányú, hagyományosan inkább ortopéd-traumatológus által végzett diagnosztikáról a német típusú ellátási rendszerekben számoltak be leginkább $(2,16-18,24,27)$.

Gyermekkorban a mozgásszervi ultrahang szerepe felértékelődik, mivel ionizáló sugárzással nem jár, relatíve olcsó, non-invazív diagnosztikai módszerröl van szó. Cikkünkben áttekintést nyújtunk a gyermekkori ultrahangos törésdiagnosztika módszeréröl, illetve bemutatjuk a lehetséges alkalmazási területeket.

\section{FIZIKAI ALAPOK}

A csontot érő ultrahangnyaláb lényegében teljes egészében reflektálódik. A csöves csontok corticalisát, arra merólegesen és hossztengelyére párhuzamosan tartott lineáris transzducerról kibocsátott ultrahangnyalábokkal, egyenes vonalként lehet leképezni. A modern készülékekkel akár már néhány tizedmilliméter nagyságú corticalis megszakadás is vizualizálható (12). A gyermekkorra jellemző, csontcorticalis deformációval járó sérülések (torus törések, angulatióval járó zöldgally törések) típusos mintázatot adnak (7). A törési résben képződő fokozatosan csontosodó, kezdetben lágy callus jelenléte az ultrahangnyalábok részleges visszaverése miatt jóval hamarabb látható. Ezt a törésgyógyulás korai detektálásában, illetve callodiastasis ellenőrzésében (végtaghosszabbítás) lehet kihasználni (1. ábra) $(26,50)$. A nagyrészt porcos elemeket tartalmazó, még minimális ossificatiót mutató, hagyományos rontgen számára sokszor "láthatatlan" izületi alkotóelemek (apophysis magok, avulsiós fragmentumok) is sokszor vizualizálhatóak ultrahanggal (46). 


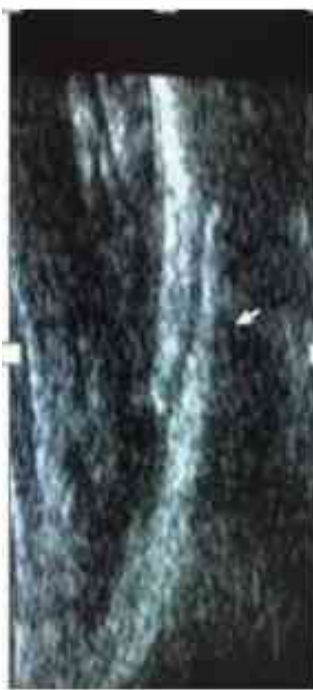

a

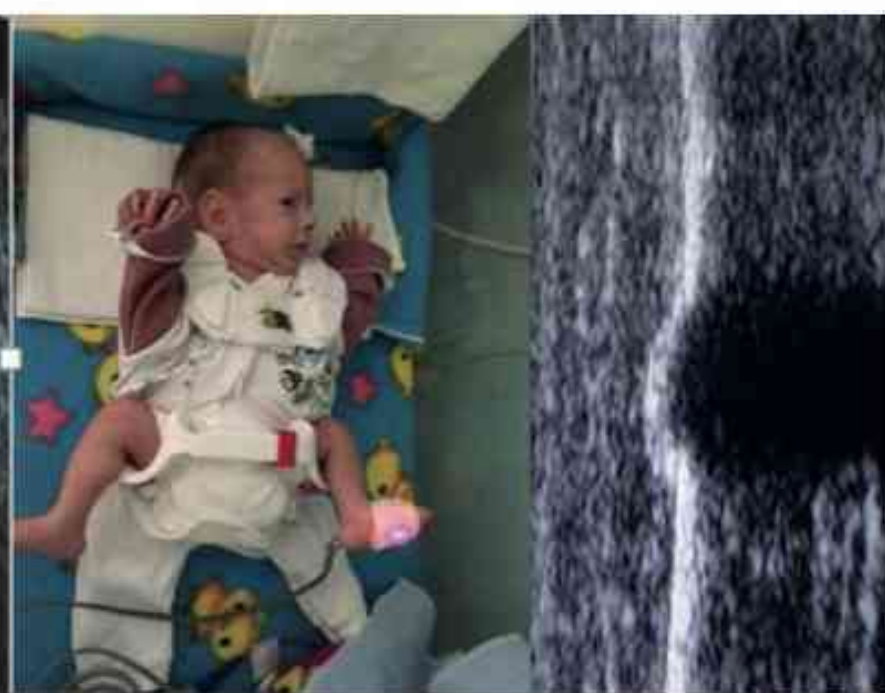

b c

\section{1. ábra}

a) Koraszülött gyermek femur diaphysis törése

b) A femurtörés ebben az életkorban 1-2 hét alatt konszolidálódik, a kezelés konzervativ c) Két héttel kẻsóbb készült ultrahangfelvételen a csont corticalison kialakuló dombszerü elóboltosulás szolid callus jelenlétére utal, a felhelyezett brace biztonsággal eltávolítható, röntgen kontroll nem szükséges

\section{SZEMÉLYI ÉS TÁRGYI FELTÉTELEK}

A célzott törésdiagnosztikára irányuló ultrahangvizsgálathoz a szonográfiás alapképzettség már elegendő lehet, ugyanakkor fontos szempont a gyermektraumatológiai ellátásban való jártasság is. Bár a csontok corticalisa egyszerübb, alacsonyabb frekvenciájú $(10-12 \mathrm{MHz})$ lienáris transzducerekkel is leképezhető, a környező lágyrészek vizsgálata, illetve az egyes rétegek határozott elkülönítése csak magasabb frekvenciájú (>10-18 MHz), nagyfelbontású készülékkel valósitható meg. Az ellenoldal vizsgálatát összehasonlítás céljából általában érdemes elvégezni. A modern készülékekben a betegek rögzitett ultrahangos képei tárolhatók, visszakereshetők.

\section{ALKALMAZÁSI LEHETÓSÉGEK TESTTÁJÉKOK SZERINT}

\section{Koponyatörések}

Gyermekkorban a fejsérülés az egyik vezetô halálok. A gyermekkori koponya trauma optimális diagnosztikus algoritmusa, illetve a potenciálisan súlyos következményekkel járó esetek kiszúrése a mai napig szakmai vita tárgya. A hagyományos kétirányú koponyaröntgen-felvételek alacsony szenzitivitásuk, míg a CT felvételek magas sugárterhelésük miatt nem alkalmazhatóak minden esetben és rutinszerúen. Boltozati, körülírt duzzanat, illetve fluktuáló terime esetén az ultrahang értékes kiegészitő képalkotó eljárás a koponyacsont-folytonosság megszakadásának igazolásában. Hátránya, hogy csak akkor informativ, ha a törés az erőbehatás területén alakul ki. A vizsgálatokat legalább két, egymásra merőleges síkban el kell végezni. Bár fejsérülés esetén az ultrahang csak kiegészítő diagnosztikus metódus, prioritását a hagyományos röntgenfelvételekkel szemben számos tanulmány igazolta $(13,36,39)$. (2-3. ábra). 


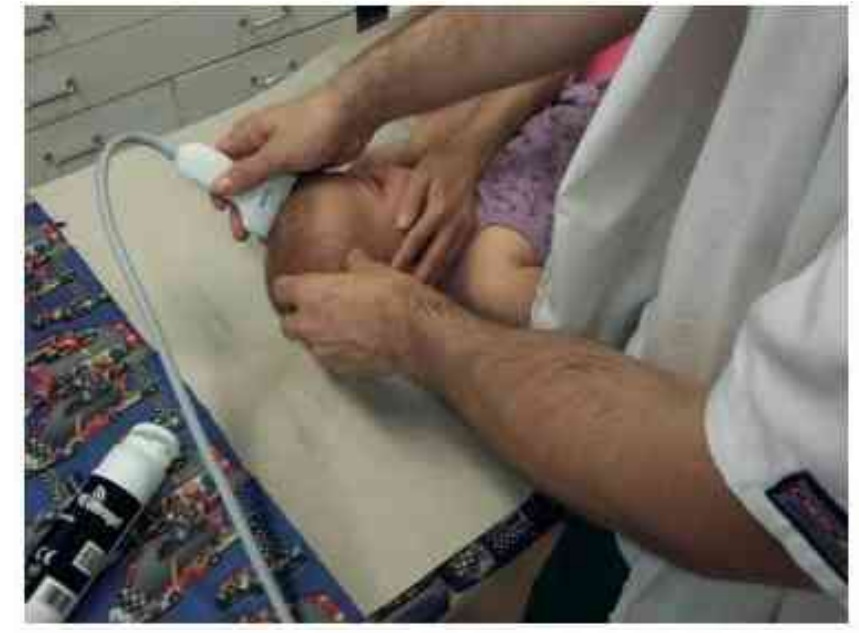

2. ábra Koponya vizsgálata ultrahanggal

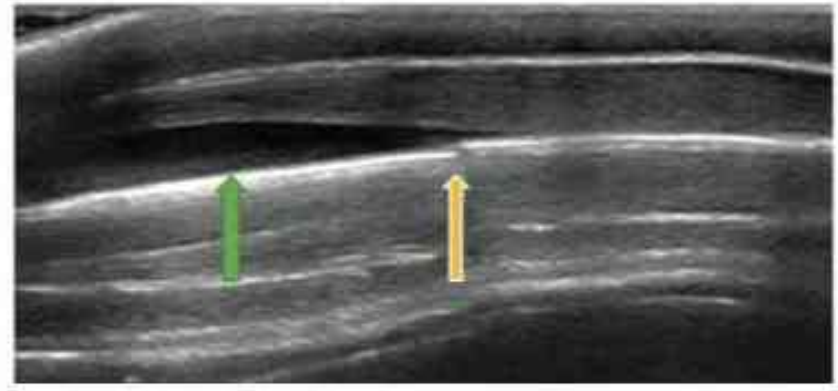

3. ábra Koponya boltozati csont törése. Az ultrahang felvételen jól látszik a csont corticalis megszakadása (sárga nyil), illetve a subgalealis haematoma (zöld nyil)

\section{Clavicula törések, proximalis humerus törések}

A gyermekkori kulcscsont- és proximalis felkarcsont-törések többnyire típusos mintázatot mutatnak, és a legtöbb esetben konzervatívan kezelhetőek. A humerus, illetve proximalis metaphysis periostealis folytonosság

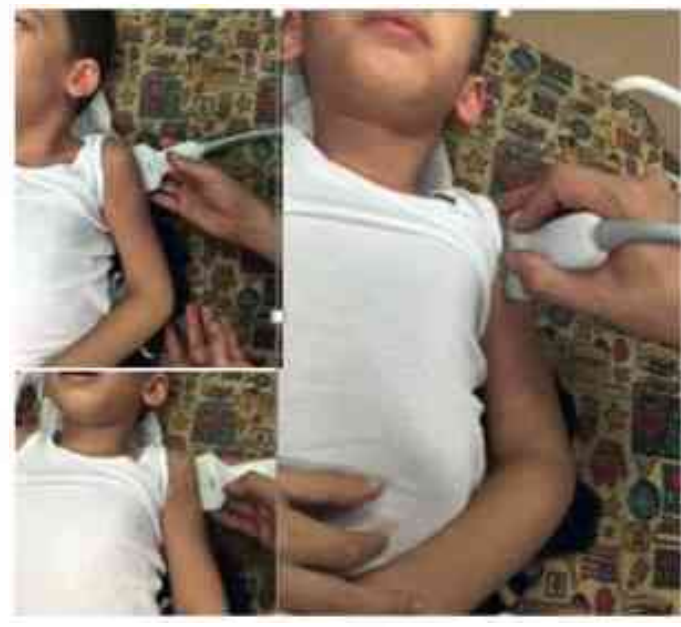

4. ábra

Proximalis humerus törés vizsgálata. A három síkból végzett vizsgálat a gyermek vállának fájdalmas mobilizációja nélkül elvégezhetö megtartottságával járó angulált, vagy torus törései, valamint a clavicula hasonló sérülései a röntgenfelvételekkel lényegében egyezô effektivitással igazolhatóak. Nagy dislocatióval járó, esetlegesen mútéti ellátást igénylő sérülések során az ultrahang igazolja a súlyosság fokát, de a pontos konfiguráció megitéléséhez a röntgen elengedhetetlen $(1,15)(4-5$. ábra).
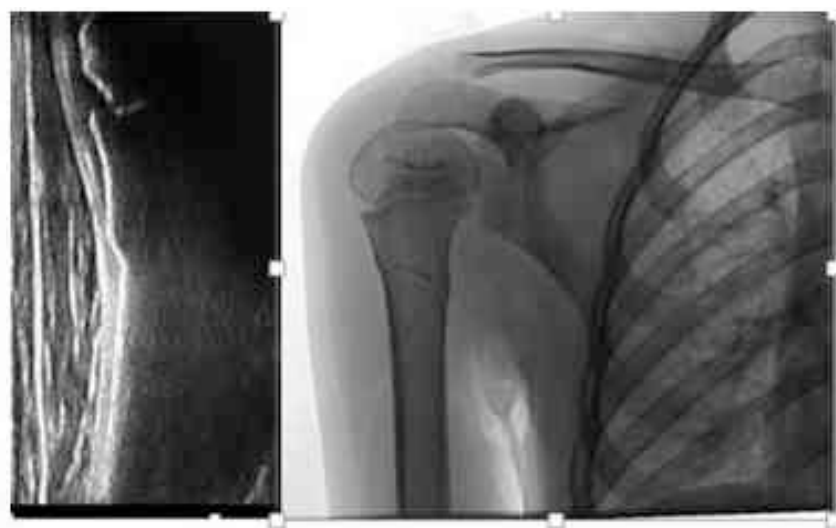

\section{5. dibra}

Proximalis humerus metaphysis torus jellegü törésének ultrahang-és röntgenkèpe.

A fehèr nyil az epiphysis fúgára, a piros nyil a torus törésre mutat. 


\section{Könyöktáji törések}

A gyermekkori könyöktáji törések nagyon gyakoriak tízéves kor alatt. A diagnosztikát nehezíti, hogy a könyökízület több csontosodási magból fejlődik, amelyek megjelenése változó. A könyökízület porcos részeit érintő törések röntgenfelvételen sokszor egyáltalán nem láthatóak, pedig akár mútéti indikációval is járhatnak. Ultrahang segitségével vizsgálható a dorsalis szonográfiás zsírpárna jel (az intraarticularis és extrasynovialis zsírpárna kóros elhelyezkedésének, a zsírpárna dislocatiójának) jelenléte, illetve hiánya, amely a radiológiai zsírpárna jelnél sokkal szenzitívebb. A vizsgálat során a fossa olecrani fölé helyezett transzducerrel igazolható, hogy a zsirpárna dislocatiójakor, annak előboltosulása a humerus corticalisának szintjét meghaladja-e. Negativ esetben a klinikai konzekvenciával járó intraarticularis törés jelenléte lényegében kizárható. További standard sikok vizsgálatával a diagnosztika még hatékonyabbá tehető $(1,17$, 18) (6-7. ábra).

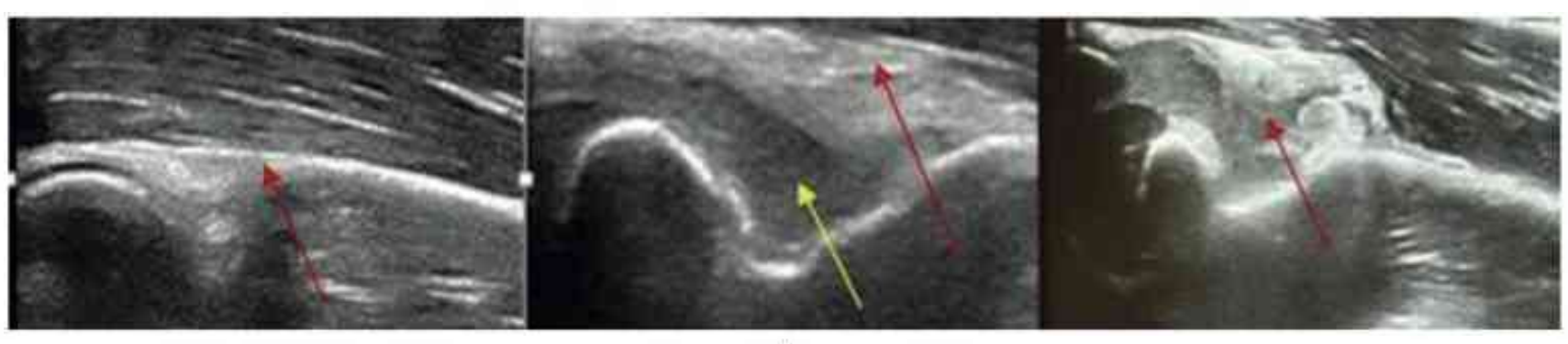

a c

6. ábra

a) Szonográfiás zsirpárna jelek a fossa olecraniban (longitudinális metszet). A szabályos elhelyezkedésü dorsalis echodús zsirpárna (normális zsirpárna jel)) lényegében az intraarticularis törés jelenlétét kizárja (piros nyil)

b) Elevált zsirpárna jel. A normál echodús zsirpárna (piros nyil) kiemelkedik a kóros izületi folyadékgyülem (sárga nyil) miatt. (zületi vérzésre, illetve okkult könyöktäji törésre utal.

c) Lipohaemarthros. A fossa olecraniban inhomogén bevérzésre jellemzö, belsó echokat tartatmazó, kóros folyadékgyülem megjelenése könyöktáji törés jele (piros nyil)

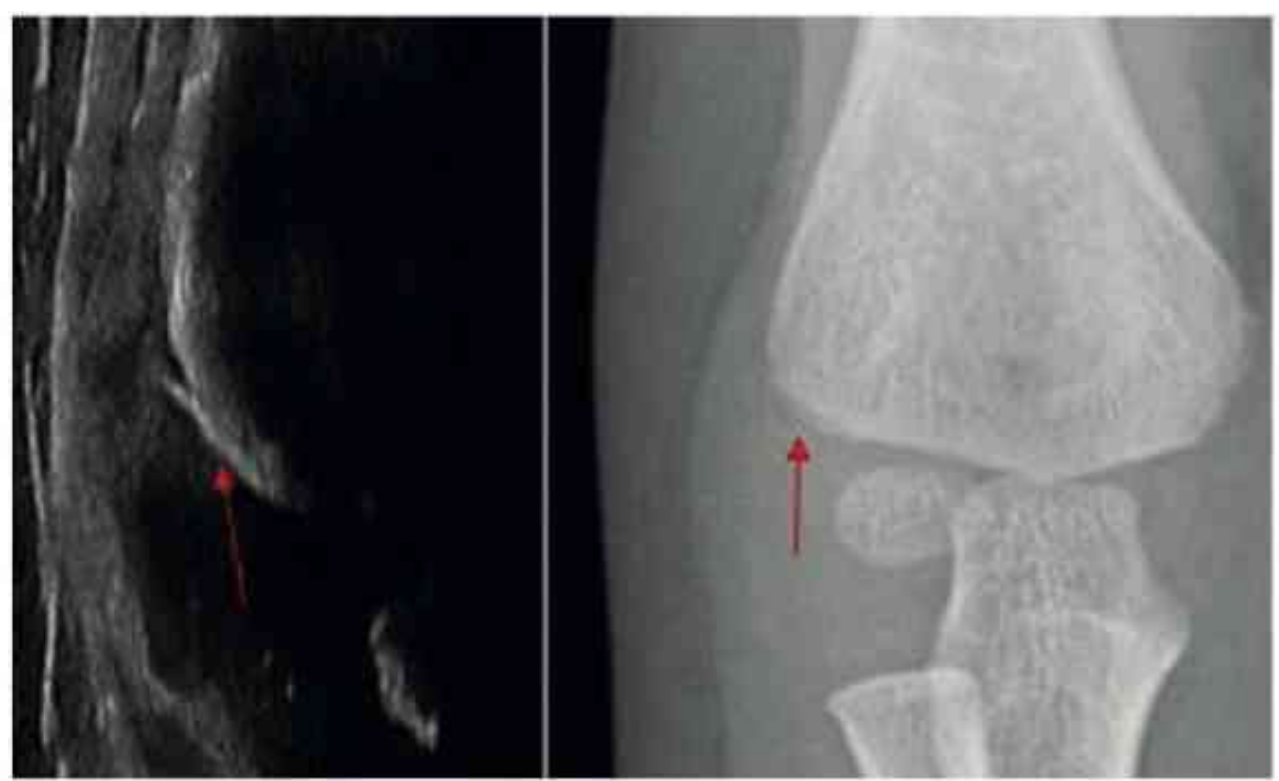

7. ábra

Elmozdulás nélküli radialis condylus törés ultrahang-és röntgenképe. 


\section{Distalis alkartörések}

A gyermekkori csuklótáji törések a gyermekkor leggyakoribb sérülései. A szonográfiás törésdiagnosztika legáltalánosabban tanulmányozott régiója. Több tanulmány is igazolta, hogy a szonográfia ugyanolyan hatékony, mint a röntgen a gyermekkori distalis radius és ulnatörések esetén (1, 44, 48, 51). A vizsgálat hat standard sík felvételével néhány perc alatt elvégezhetô (48). Remodellációs kapacitást meghaladó angulációval járó tôrések, vagy dislocált epiphyseolysisek esetén a repozíció eredményessége röntgen helyett ultrahangvizsgálattal is ellenőrizhető (51) (8-9. ábra).

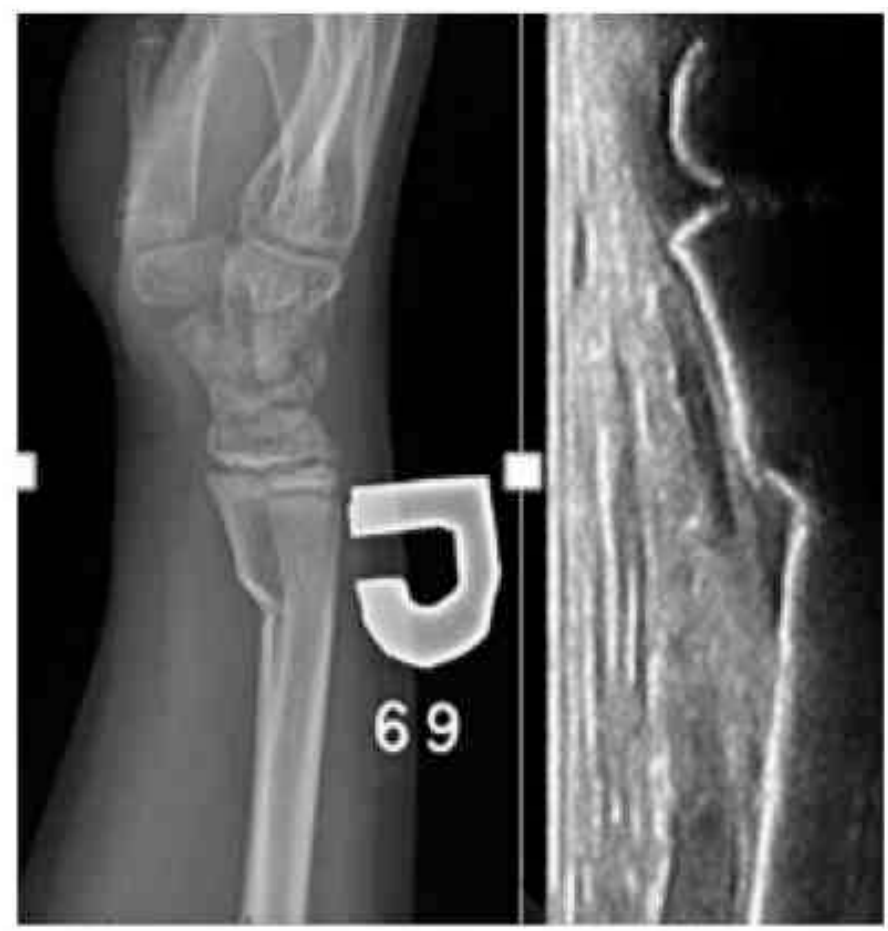

8. ábra

Jelzett ventraiis billenéssel járó distalis radius metaphysis törés röntgen-és ultrahangképe
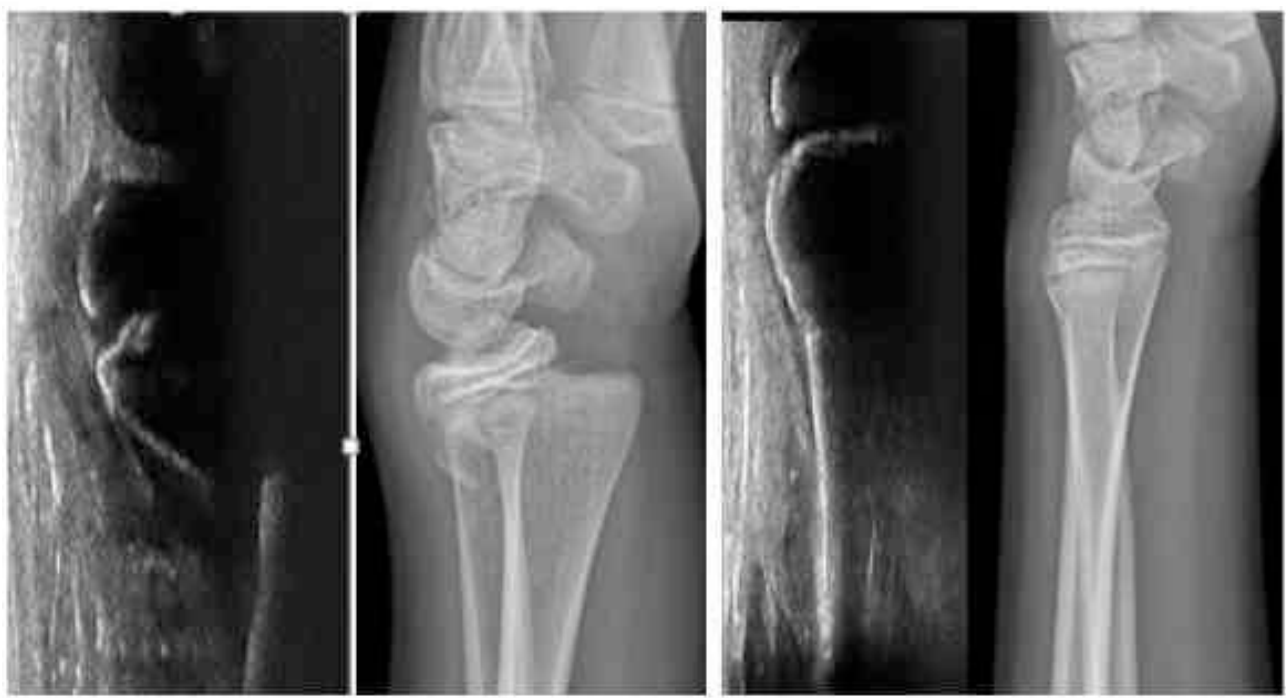

9. ábra

Salter-Harris II-es epiphyseolysis ultrahang-és röntgenképe, valamint a repozició után készült ultrahang-és röntgenfelvételek 


\section{Kézközépcsont és ujjtörések}

A hosszú ujjak PIP és DIP ízületi avulsiói, epiphyseolysisei, illetve a metacarpusok diaphysisét, végpercét érintổ törések egyaránt jól vizualizálhatóak gyermekkorban. Hasonlóan a csuklótájékhoz az V-ös metacarpus fej billenéssel járó törései reponálhatóak is szonográfiás ellenőrzés mellett. A mütéti indikációt képezó tengelyeltérések, diastasisok ugyancsak észlelhetőek, de ezekben az esetekben pontos ábrázolás csak röntgen igénybevétele mellett lehetséges $(4,47)$.

\section{Csipótáji sérülések}

Számos gyermekkori, a csípôt érintő patológiás folyamattal elöször baleseti ambulancián jelentkeznek elsődleges ellátásra, mert sokszor valamilyen sérüléssel hozzák összefüggésbe. A csípő elülső ferde síkból végzett ultrahangos gyorsdiagnosztikájának a hagyományos röntgendiagnosztika mellett számos elönye lehet. Bár a csipőizületi folyadékszaporulat ritkán utal traumára, jelenléte, rutin szürése, gyermekkori csípö- és térdtáji fájdalmak esetén nagyon sok segitséget nyújthat egyes kórképek megerósítésében, illetve kizárásában.

A három leggyakoribb gyermekkori csípótáji folyamat - transitorius coxitis, Legg-Calvé-Perthes kór, illetve serdülökori combfej epiphyseolysis - fennállása jóval hamarabb megállapító. Serdülőkori combfej epiphyseolysis kezdeti stádiumában az ultrahangon látható lehet az ízületi folyadékszaporulat, valamint az epiphysis fúga kiszélesedése, igy szenzitivebb lehet a röntgennél, amely ilyenkor gyakran még semmilyen elváltozást nem mutat $(14,35)$.

A részben elcsontosodott medencetáji apophysis magok serdülökori avulsiós törései többnyire sportolás, illetve hirtelen nagy energiájú izomtevékenység során alakulnak ki, hagyományos röntgenfelvételekkel gyakran nagyon nehéz a megitélésük és differenciáldiagnosztikai problémát jelenthetnek. Célzott ultrahangvizsgálat megerősitheti a klinikai gyanút (10. ábra).

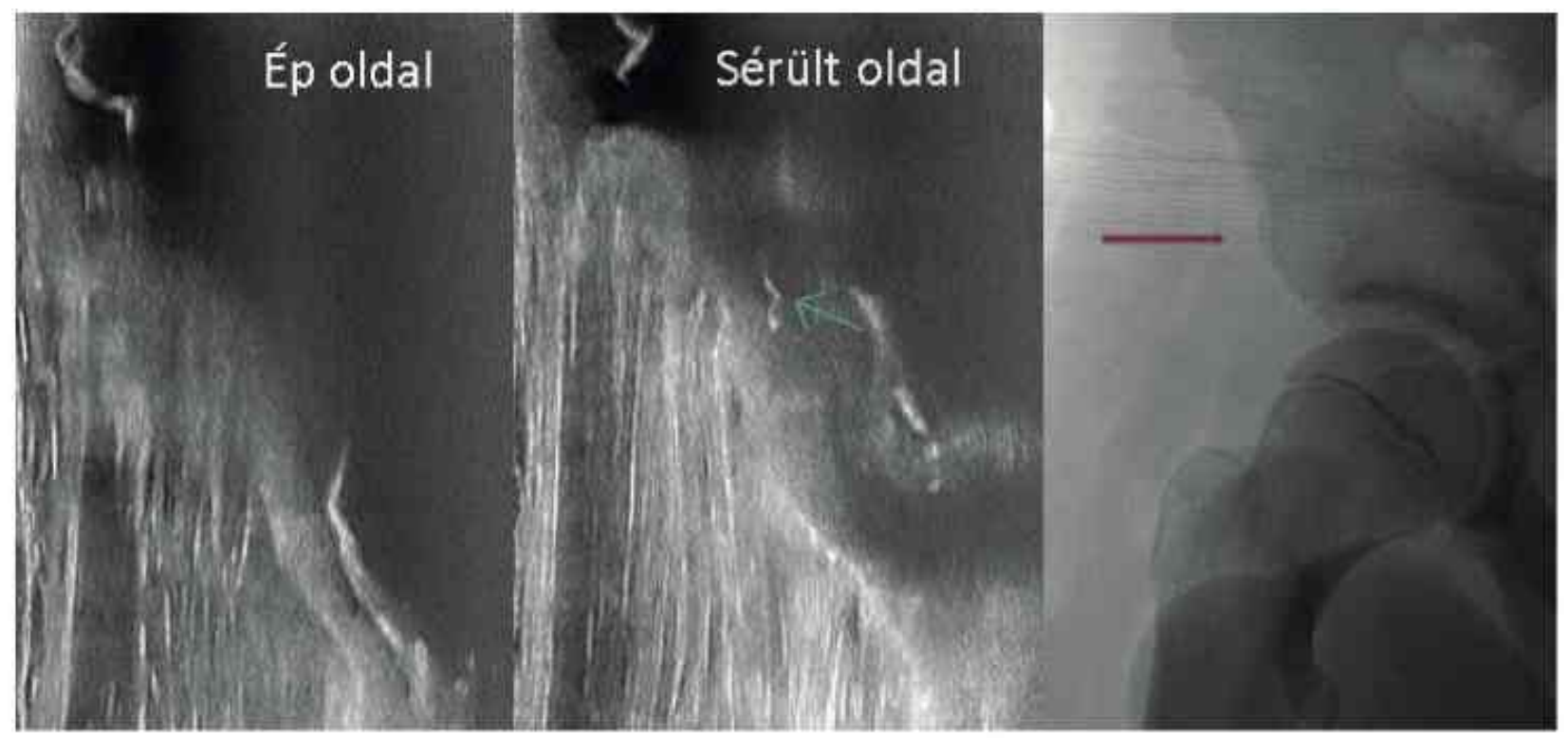

10. ábra

Spina iliaca anterior inferior avulsiós törése 15 éves sportoló gyermeknél. Míg a röntgenfelvételen csak sejthetó a törés (piros nyil), az összehasonlitó ultrahangképen az ép oldallal összehasonlitva egyértelmüen látható az avulsiós fragmentum (zöld nyil). 


\section{Térdtáji sérülések}

A gyermekkorban jelentkező térdtáji panaszok hátterében számos patológiás folyamat húzódhat. A diagnosztikát nehezíti, hogy a gyermekek elsődleges vizsgálata sokszor egyáltalán nem mozgásszervi specialista által történik. Hasonlóan a csípőizülethez, a térdízületi folyadékszaporulat - amely szonográfiával nagyon szenzitiven, egyszerủen igazolható - mindig patológiás folyamatra (törés, szalagsérülés, gyulladás) utal. Röntgenfelvétellel nem igazolható okkult törések, porcfelszín sérülés, retinaculum avulsiós törések, amelyek terápiás konzekvenciát jelenthetnek is észlelhetőek „point of care” ultrahanggal. A fenti esetekben a legföbb elöny, hogy a gyors, sugárterheléssel nem járó és olcsó vizsgálat felhivhatja a figyelmet a további relatív sürgős diagnosztika (MRI) és terápia (artroszkópia) s7ükségességére $(3,6,28,29)(11-12$ ábra).

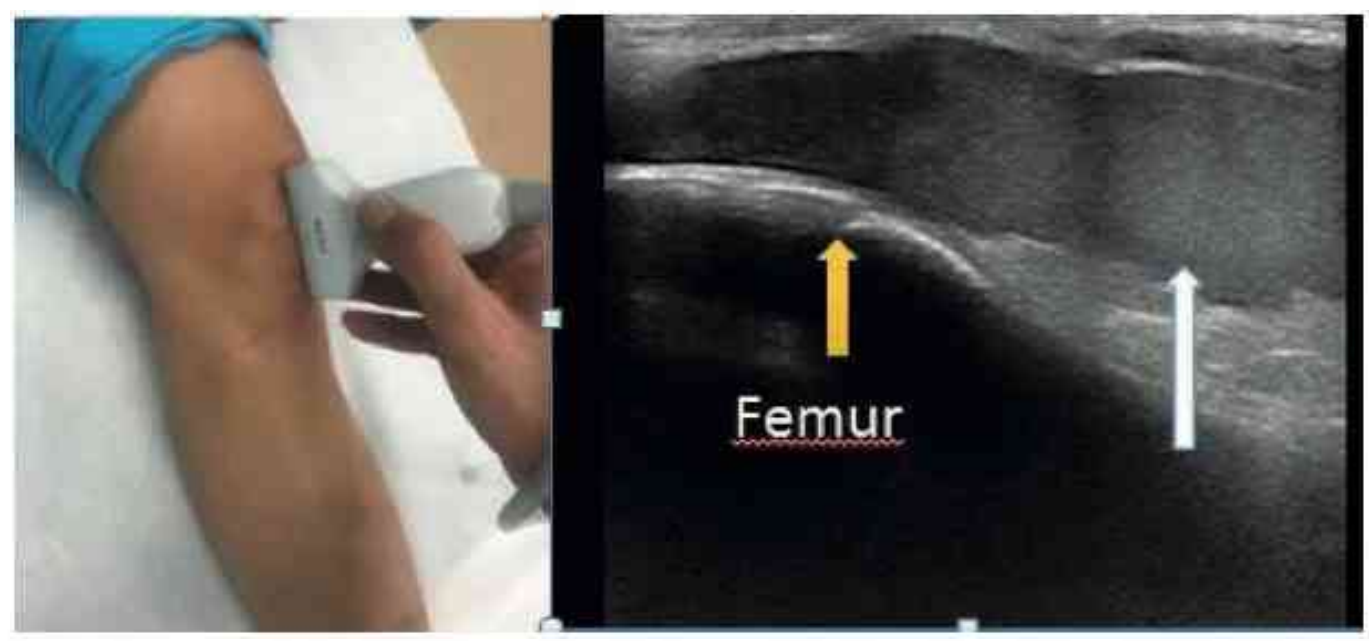

11. ábra

Haemarthros genus vizsgálata és ultrahangképe. A longitudinális sikban végzett vizsgálattal látható a femur corticalisa, illetve a növekedési zóna (sárga nyil), valamint a recessus suprapatellarisban elhelyezkedo jelentös mennyiségü, sürü, csaknem homogén izületi folyadékgyülem (fehér nyil)

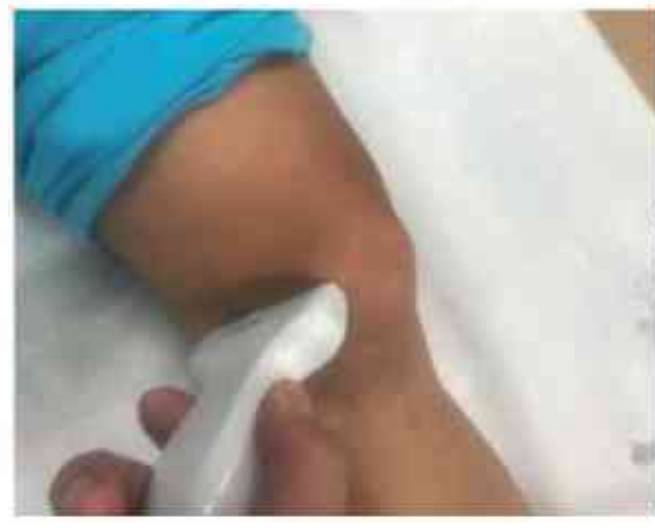

Patellaficam utáni állapot, medialis retinaculum vizs gálata. Az ép oldallal összehasonlitva látható, hogy a medialis retinaculum szabályos szerkezete (fehér nyil) a sérült oldalon a patellán történô topadásnál, a kis avulsiós fragmentum (piros nyil). A retinaculum alatt folyadékgyülem lätható (sárga nyil) 


\section{Lábszártörések}

Gyermekkori lábszársérülések esetén az ultrahang effektíven alkalmazható a nagy dislocatióval járó törések primer rögzítése, vagy helyretétele során a megfelelő tengelyállás ellenôrzésére, illetve konzervatív kezelés során a redislocatio kizárására.

A még csak részleges csontosodást mutató tuberositas tibiae avulsiós töréseinél is fontos szerepe lehet az ultrahangnak a sérülés fokának megítélésében.

Speciális eset a kisgyermekkori kis traumára kialakuló izolált tibia infractiós sérülés (Toddler's fracture), amely a primeren sokszor negativ röntgenfelvételek miatt sokszor kifejezett differenciáldiagnosztikai problémát jelent. A csont corticalis megszakadása ezekben az esetekben általában szonográfiával igazolható $(32,37,38)$

\section{Bokatáji törések}

A gyermekkori bokatáji sérülések rutinszerüen alkalmazott diagnosztikus vizsgálata a háromirányú röntgenfelvétel. Ismert tény

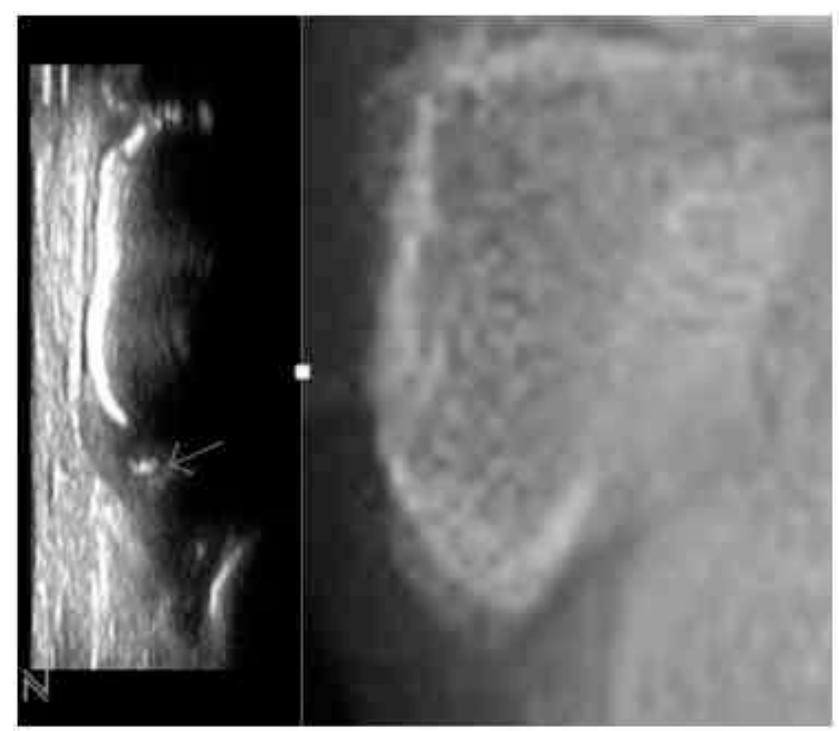

13. ábra

Külboka avulsiós törés ultrahangképe. A röntgenfelvételen csak sejthetö, hogy a külboka csúcsából egy kis fragmentum kiszakadt (nyii) ugyanakkor, hogy gyermekkorban csak az esetek kevesebb, mint 5\%-ában igazolódik csontos eltérés. Emiatt egyes ajánlások csak a járásképtelenséggel és nagy duzzanattal járó esetekben javasolják egyáltalán a röntgen képalkotás igénybevételét. Néhány szerzố a röntgenhez hasonló diagnosztikus értékűnek találta az ultrahangot a külbokatörések kizárásában. A gyermekkora jellemző fibula distalis vég héjszerú szalagos avulsiói sokszor csak ultrahanggal vizualizálhatóak. A fentiek alapján járásképességüket megtartott, bokasérült gyermekek esetén sokkal inkább az ultrahang lenne optimális az elsődlegesen választandó képalkotó eljárásnak $(19,33)(13$ ábra).

\section{Lábcsont-törések}

A lábujjak, metatarsusok sérülései a kéz ujjaihoz hasonló effektivitással vizsgálhatóak. $\mathrm{Az}$ ultrahang kifejezett segítséget nyújthat az V. metatarsus bázistörések megítélésében, valamint a törés, illetve korcsoportra jellemzö apophysis magok elkülönitésében $(30,40)$ (14. ábra), illetve az avulsiós sérülések diagnosztizálásában.

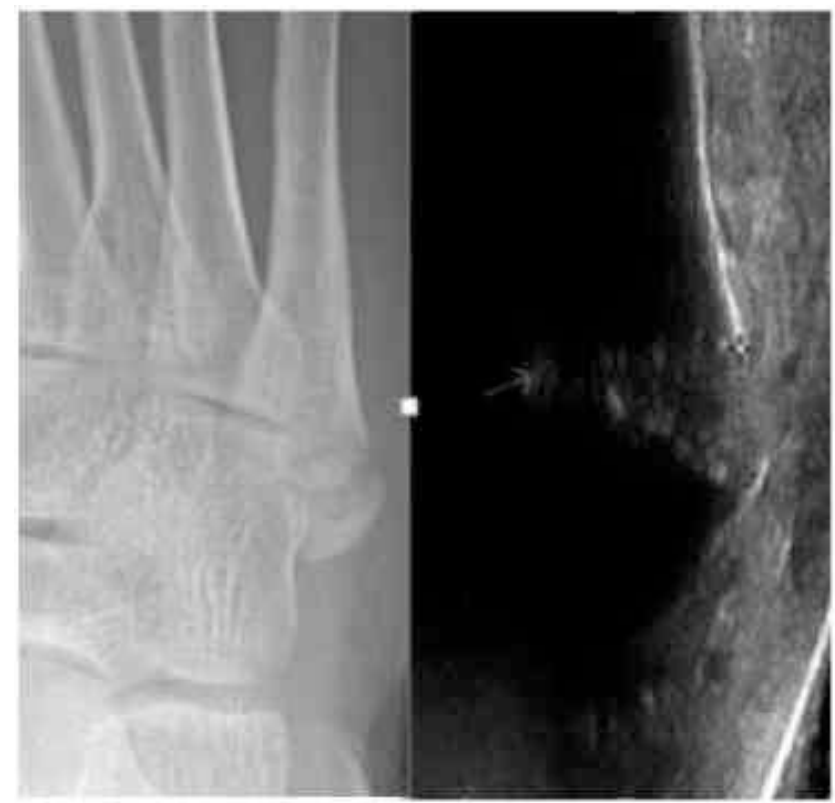

14. ábra

Metatarsus bázistörés röntgen-és ultrahangképe. A törésben kialakult diastasis megitélése hagyományos röntgenfelvételen sokszor nehéz. A lateralis sikból felhelyezett transzdúcer segítségével az elmozdulás mértéke ultrahangvizsgálattal pontosan meghatározható (nyil) 


\section{SPECIÁLIS ESETEK}

\section{Gyermekbántalmazás}

Gyermekbántalmazás gyanúja esetén az ultrahang jelentôs segítséget nyújthat egyéb régebbi, addig nem felismerésre került törések detektálásában. Szonográfiával a csöves csontok további potenciális sérüléseinek szürése effektiven végezhetö el, ennek különösen kisdedek, kisgyermekek subperiostealis töréseinek esetén van jelentốsége. Ezekben az esetekben a callusképződés gyorsan bekövetkezik, így a törés klinikailag már kevésbé észlelhetô, ha a gyermeket később viszik orvoshoz
- ugyanakkor az ossificálódó csonthártya alatti haematoma jellegzetes ultrahang képe sokáig vizualizálható $(34,49)$.

\section{Stressztörések}

Az ultrahangnak nagy szerepe lehet különböző stressztörések korai identifikálásában. Stressztörésre utalhat a megvastagodott periosteum, a corticalis vonalának disruptiója, illetve Doppler aktivitâs fokozódása, a hypervascularisatio megjelenése az érintett csontszegmens környezetében. Ezek a jelek akár hetekkel korábban is kimutathatóak, mint a röntgenfelvételen legkorábban látható morfológiai elváltozások $(21,23)(15 . a ́ b r a)$.

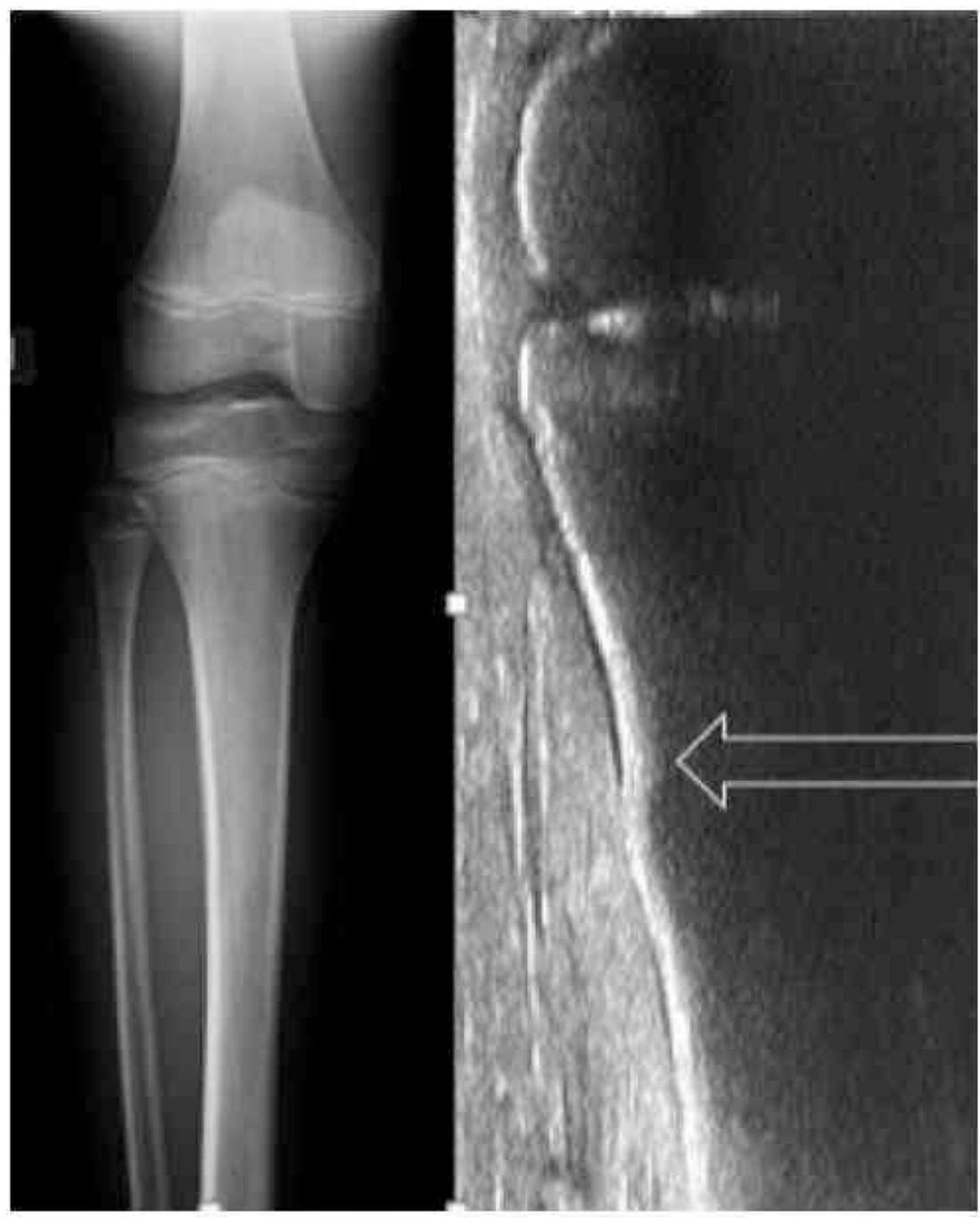

15. ábra

Élsportoló gyermek lateralis térdfájdalmát okozó proximalis fáradásos fibulatörés. A csont corticalison látható megvastagodás már a callusképzódés jele (nyil) 


\section{MEGBESZÉLÉS}

A fentiekben több olyan régiót soroltunk fel, ahol a gyermekkori ultrahangos törésdiagnosztika relative egyszerüen és sürgősségi ellátásban alapszintú képesitéssel is alkalmazható lenne. $\mathrm{Az}$ irodalomban számos beszámolót találunk egyéb csonttörések sikeres diagnosztikájáról is - ezek azonban vagy magasabb szintû szonográfiás képzettséget igényelnek, vagy jóval alacsonyabb szenzitivitású, specificitású egyedi esetek - semmiképpen nem a rutin részei (42). Az akut gyermektraumatológiai ellátás során ugyanakkor minimum az esetek 70-80\%-ában a fenti régiók valamelyike sérül, igy az ultrahangnak különösen nagy szerepe lehetne az ellátás gyorsításában, a differenciáldiagnosztikában, illetve a fölösleges röntgenvizsgálatok redukciójában (42).

Bár az ultrahang törésdiagnosztikai hatékonysága évtizedek óta ismert, a mai napig nem állnak rendelkezésünkre magas szintű evidenciák, amelyek a fentiekben részletezett alkalmazási lehetőségeket tudományosan alátámasztanák. $\mathrm{Az}$ irodalomban fellelhetố számos közlemény jelentős része sürgősségi osztályok vagy egy-egy centrum által végzett relativ kisebb esetszámok alapján vonta le következtetéseit (42).

Az Európai Musculoskeletalis Radiológiai Társaság (European Society of Musculoskeletal Radiology - ESSR) 2017-ben kiadott egy közleményt, amely a mozgásszervi ultrahangvizsgálatok egyes kórképekre vonatkozó jelenlegi evidenciáit is tartalmazza. A konszenzus szerint több régió törése (könyök, térd, proximalis humerus, tibia) is vizsgálhato ultrahanggal, de a jelenlegi információk birtokában ez többnyire egyéb képalkotó lehetőségek hiányában ajánlott, és az ultrahangos törésdiagnosztika hatékonyságáról egyáltalán nem állnak rendelkezésre A-típusú bizonyítékok (43).

Az Európai Orvosi és Biológiai Ultrahang Társaságok Szövetsége (EFSUMB) 2016-ban kiadott egy kifejezetten gyermekkorra vonatkoztatott ajánlást, amely egyaránt tartalmazza a módszertani, dokumentációs, személyi és tárgyi feltételeit a legbiztonságosabban alkalmazható gyermekkori proximalis és distalis humerus, valamint distalis alkari törések szonográfiás diagnosztikájának, de a módszer egyelóre nem elfogadott rutineljárás része sehol a világon (1).

Eddig egy hazai közlemény jelent meg a témában, amely distalis alkartörések ultrahangos vizsgálata során két centrum, összesen 437 esetszámát elemezve, a nemzetközi irodalomban fellelhetőekhez hasonlóan kedvezó eredményre jutott (48).

$\mathrm{Az}$ Országos Traumatológiai Intézetben 2011 óta foglalkozunk gyermekkori szonográfiás törésdiagnosztikával, az utóbbi években több gyermektraumatológiai centrum (Budapest, Heim Pál Kórház, Pécs, Szeged) is elkezdte alkalmazását. A módszer hazai protokolljának és jogi hátterének megteremtése még várat magára.

$\mathrm{Az}$ egyes anatómiai régiók további nagy esetszámú, prospektiv és multicentrikus vizsgálatán és a tárgyi feltételek megteremtésén túl a rutin ultrahangos törésdiagnosztika további feltétele az alapszintű musculoskeletalis ultrahangos oktatás ortopéd-traumatológiai szakképzésbe való iktatása is. A szerzók hangsúlyozzák, hogy az ultrahangos törésdiagnosztika célja nem a röntgenfelvételek mellózése, hanem egy, a hagyományos rutin radiológiai eljárásokat kiegészitő, azt ésszerüen redukáló, ellátást gyorsitó, esetenként további információkat adó költséghatékony metódus megteremtése. 


\section{IRODALOM}

1. Ackermann I., Eckert K.: Bone fracture ultrasound. EFSUMB Course Book. 07. 07. 2015. 12: 48.

2. Ackermann 0 ., Liedgens P., Eckert K., Chelangattucherry E., Ruelander C, Emmanouilidis I., Ruchholtz S.: Uitrasound diagnosis of juvenile forearm fractures. 1. Med. Uitrason. (2001). 2010. 37. (3): 123-127.

3. AcunaJ., Situ-LaCasse E., Jamplis R. P., Amini R., Adhikari S.: Point-of-care ultrasound evaluation of tibial avulsion fractures. Cureus, 2018. 10. (5): e2677 hittosi//doi.ora/10.7759/cureus.2677

4. Aksay E., Kilic T. Y., Yesilaras M., Tur F. C., Sever M., Katenderer O.: Accuracy of bedside ultrasonagraphy for the diagnosis of finger fractures. Am. 1. Emerg. Med. 2016. 34. (5): 809-812. hittps://dol,ora/10.1016/1. ajem.2016.01.010

5. Alexander J. E., Seibert J. J., Glasier C. M., Williamson S. L., Aronson J., McCarthy R. E. Rodgers A. B., Corbitt S. L.: High-resolution hip ultrasound in the limping child. J. Clin. Ultrasound, 1989. 17. (1): $19-24$. hites://dol, ora/10.1002/icu.1870170105

6. Aponte E. M., Novik J.I.: Identification of lipohemarthrosis with point-of-care emergency ultrasonography: case report and brief literature review. I. Emerg. Med. 2013. 44. (2): 453-456. httos:l/doi.org/10.1016/1.jemermed.2012.07.062

7. Barata I, Spencer R, Suppiah A, Raio C, Ward MF, Sama A.: Emergency ultrasound in the detection of pediatric long-bone fractures. Pediatr. Emerg. Care, 2012. 28. (11): 1154-1157. hitos://doi.org/10.1097/PEC.0b013e3182716fb7

8. Blankstein A.: Uitrasound in the diagnosis of clinical orthopedics: The orthopedic stethoscope World J. Orthop. 2011. 2. (2): 13-24. bitps://dolore/10.5312/wio.v2.12.13

9. Bonasso P. C, Dassinger M. S., Wrick D. L, Gurien L. A., Burford I. M., Smith S. D.: Review of bedside surgeon-performed

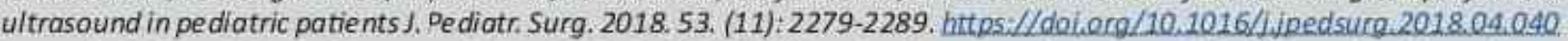

10. Bozorgia F., Azarb M. S., Montazera S. H., Heidaria S. F, Khalilianc A. Accuracy of ultrasound for diagnosis of femur bone fractures in traumatic patients. 1. Clin. Exp. Orthop. 2017. 3:27.

11. Chartier L. B., Bosco L., Lapointe-Shaw L, Chenkin J.: Use of point-af-care ultrasound in long bone fractures: a systematic review and meta-analysis. CIEM, 2017. 19. (2): 131-142. https://doi.org/10.1017/cem. 2016.397

12. Chen K. C., Lin A. C., Chong C. F., Wang T. L: An overview of point-of-care ultrasound for soft tissue and musculoskeletal applications in the emergency department. I. Intensive Care, 2016, 4:55, https://dolora/10,1186/540560-016-0173-0

13. Choi J. Y., Lim Y. S., Jang J. H., Park W. B., Hyun S. Y., Cho J. S.: Accuracy of bedside ultrasound for the diagnosis of skull fractures in children aged 0 to 4 years. Pediatr. Emerg. Care, 2018. Apr 24. [Epub ahead of print] hittos://dolorg/10.1097/PEC0000000000001485

14. Cook P. C.: Transient synovitis, septic hip, and Legg-Calvé-Perthes disease: an approach to the correct diagnosis. Pediatr. Clin. North Am. 2014. 61. (6): 1109-1118. httos://dojorg/10.1016/i.pcl.2014.08.002

15. Cross K. P., Warkentine F. H., Kim I.K., Gracely E., Paul R. I. Bedside ultrasound diagnosis of clavicle fractures in the pediatric emergency department. Acad. Emerg. Med. 2010. 17. (7): 687-693. httos://doi ora/10.1211/1.1553-2212.2020.00788. X

16. Eckert K., Ackermann O., Schweiger B., Radeloff E., Liedgens P. Sonographic diagnosis of metaphyseal forearm fractures in children: $a$ safe and applicable alternative to standard x-rays Pediatr. Emerg. Care, 2012. 28. (9): $851-854$. hittos: /dotora/10.1097/PEC.0b013e318267a73d

17. Eckert K., Ackermann O., Schweiger B., Radeloff E, Liedgens P.: Ultrasound evaluation of elbow fractures in children. J. Med. Uitrason. (2001). 2013, 40. (4):443-451.

18. Eckert K., Ackermann O.: Sonographische Frakturdiagnostik. Radiologe, 2015. 55. (11): 992-924, 996-999.

19. Ekinci S., Polat O., Günalp M., Demirkan A., Kaca A.: The accuracy of ultrasound evaluation in foot and ankle trauma. Am. 1. Emerg. Med. 2013. 31. (11): 1551-1555. hittpsil/doi.ora/10.1016/1 ajem.2013,06.008

20. Farbaky Zs.: A mozgásszervi ultrahangvizsgálat alapjai. 4. kiad. Bp. Tordas K, 2017.

21. Fukushima Y., Ray J., Kraus E, Syrop I. R, Fredericson M. A.: A review and proposed rationale for the use of ultrasonography as a diagnostic modality in the identification of bone stress injuries. J. Ultrasound Med. 2018. 37. (10): 2297-2307. hittos://doiora/10.1002/jum.14588

22. Gleeson T. Blefiur D.: Puint-uf-cure ultrusound in Lrauma. Semin. Ultrasoumd CT MR, 2018. 39. (4): $374-383$. hittos://doi.ora/10.1053/i.sult.2018.03.007

23. Hoffman D. E, Adams E., Bianchi S.: Ultrasonography of fractures in sports medicine. Br. J. Sports Med. 2015. 49. (3): 152 160. hittosil/doi.org/10.1136/bisports-2014-094217

24. Hübner U., Schlicht W., Outzen S., Barthel M., Halsband H.: Ultrasound in the diagnosis of fractures in children. J. Bone Joint Surg. Br. 2000. 82-B. (8): 1170-1173. httos://doi.ora/10.1302/0301-620X.8288.0821170

25. Joshi N., Lira A., Mehta A., Palodino L, Sinert R.: Diagnostic accuracy of history, physical examination, and bedside ultrasound for diagnosis of extremity fractures in the emergency department: A systematic review. Acad. Emerg. Med. 2013. 20. (1): 1-15. hitips://doiora/10.1111/acem.12058

26. Kachewar S. G., Kulkarni D. S.: Utility of diagnostic ultrasound in evaluating fracture healing. J. Clin. Diagn. Res. 2014.8. (3): 179-180. httos:/Jolora/10,7860/JCDR/2014/4474.4159

27. Katzer C., Wasem J., Eckert K., Ackermann O., Buchberger B.: Ultrasound in the diagnostics of metaphyseal forearm fractures in children: A systematic review and cost calculation. Pediatr. Emerg. Care, 2016, 32. (6): $401-407$. httosil/doiora/10.1097/PEC 0002000000000446

28. Kilic $T, Y$, Yesilaras M., Atilla O. D., Turgut A.: The accuracy of point-of-care uitrasound as a diagnostic tool for patella fractures. Am. 1. Emerg. Med. 2016. 34. (8): 1576-1578. hittes://dol.ora/10.1016/1ajem.2016.05.073 
29. Klos B., Scholtes M., Konijnenberg S: High prevalence of all complex Segond avulsion using ultrasound imaging. Knee Surg . Sports Traumatol, Arthrosc. 2017. 25. (4): 1331-1338. hittos:lldoi.org/10.1007/s00167-017-4532-8

30. Kozaci N., Ay M. O., Avci M., Beydilli 1., Turhan S., Donertas E., Ararat E.: The comparison of radiography and pointof-care ultrasanography in the diagnosis and management of metatarsal fractures. Injury, 2017. 48. (2): $542-547$. hitos://doi ora/10.1016/4injury.2016.12.018

31. Leitgeb N., Badenteich A., Schweighofer F, Fellinger M: Sonographische Frakturdiagnostik. Ultraschall. Med. 1990. 11. (4): 206-209. hittosi//doi.org/10.1055/s-2007-1011563

32. Lewis D., Logan P.: Sonographic diagnosis of toddler's fracture in the emergency department. J. Clin. UItrasound, 2006.34. (4): 190-194. https://doi.org/10.1002/jcu.20192

33. Maeda M. Maeda N., Takaoka T., Tanaka Y: Sonographic findings of chondral avulsion fractures of the lateral ankle ligaments in children. 1. Ultrasound Med. 2017. 36. (2): 421-432. hittps://doli org/10.7863/ultra.15.09008

34. Nimkin K., Kleimman P. K., Teeger S., Spevak M. R.: Distal humetal physeal injuries in child ubuse: MR imuging and ultrasonography findings. Pediatr. Radiol. 1995. 25. (7): 562-565. httos://doi.org/10, 1007/BF02015796

35. Palaniappan M., Indiran V., Maduraimuthu P.: Uitrasonographic diagnosis of slipped capital femoral epiphysis. Pol. J. Radiol. 2017. 82, 149-151, hittpsil/dol.era/10,12659/PJR. 9005:04

36. Parri N., Crosby B. J., Glass C., Mannelli F., Sforzil., Schiavone R., Ban K. M.: Ability of emergency uitrasanography to detect pediatric skull fractures: a prospective, observational study. Emerg. Med. 2013. 44. (1): 135-141.

37. Patel R. M., Tollefson B. J.: Bedside ultrasound detection of long bone fractures. J. Miss. State Med. Assoc. 2013. 54. (6): 159-162.

38. Pearce T., Cobby M.: Radiographically occult fracture of the tibial epiphysis: sonographic findings with CT correlation. J. Clin. Ultrasound, 2011. 39. (7): 425-426. https://dolorg/10.1002/icu.20814

39. Ramirez-Schrempp D., Vinci R. Ji, Liteplo A. S.: Bedside ultrasound in the diagnosis of skull fractures in the pediatric emergency department. Pediatr. Emerg. Care, 2011. 27. (4): 312-314. httos://dol.ora/10.1097/PEC 0b013e3182131579

40. Sabour S.: Bedside ultrasonography as a diagnostic tool for the fifth metatarsal fractures: methodological concern in reliability analysis. Am. J. Emerg. Med. 2014. 32. (5): 470, hittos://dol.ora/10,1016/1.ajem.2014.01.012

41. Saul T., Ng L., Lewiss R. E.: Point-of-care ultrasound in the diagnosis of upper extremity fracture-dislocation. A pictorial essay, Med. Uitrason. 2013. 15. (3):230-236. hitos://doi.org/10.11152/mu.2013.2066,153.ts1/n2

42. Schmid G. L, Lippmann S., Unverzagt S., Hofmann C., Deutsch $T_{\text {s }}$ Frese T.: The investigation of suspected fracture - a comparison of ultrasound with conventional imaging. Systematic review and meta-analysis. Dtsch. Arztebl. int. 2017. 114. (45): $757-764$.

43. Sconfienza L. M., Albano D., Allen G., Bazzocchi A., Bignotti B., Chianca V., Facal de Castro F., Drakonaki E. E, Gallardo E., Gielen 1., Klauser A. S., Martinoll C., Mauri G., McNally E, Messina C., Mirán Mambiela R., Orlandi D., Plagou A, Posadzy M., de la Puente R., Reijnierse M., Rossi F. Rutkauskas S., Snoj Z., Vucetic 1., Wilson D., Tagliafico A. S.: Clinical indications for musculoskeletal ultrasound updated in 2017 by European Society of Musculoskeletal Radiology (ESSR) consensus. Eur. Radiol. 2018. Jun 6. [Epub ahead of print] httesi//doi oro/10,1007/s00330-018-5474-3

44. Simanovsky N., Lamdan R., Hiller N.: Sonographic detection of radiographically occult fractures in pe diatric ankle and wrist injuries. J. Pediatr. Orthop. 2009. 29. (2): 142-145. hittps://doi.ora/10.1097/BP0.0b013e318198452e

45. Tokarski J., Avner J. R., Rabiner J. E.; Reduction of radiography with point-of-care elbow ultrasonography for elbow trauma in children. J. Pediatr. 2018. 198: 214-219.e2 https://doi.org/10.1016/i.jpeds.2018.02.072

46. Tuijthof G. J., Kok A. C., Terra M.P., Aaftink L. F., Streekstra G. L., van Dijk C N., Kerkhoffs G. M.: Sensitivity and specificity of ultrasound in detecting (osteo) chondral defects: a cadaveric study. Ultrasound Med. Biol. 2013. 39. (8): 1368-1375. hittps://doi.ora/10.1016/i.ultrasmedbia. 2013.02.011

47. Tuzun H. Y. Turkkan S., Arsenishvili A., Bahtiyar E. E. Accuracy of bedside ultrasonography for the diagnosis of phalanx fractures. Am. J. Emerg. Med. 2016. 34. (8); 1698. hites:l/dol.org/10.1016/1.aiem.2016.05.029

48. Varga M., Gáti N., Kalóz E., Bíro Zs., Szeverényi Cs., Kardos D., Józsa G.: Ultrasonographic diagnosis of distal pediatric forearm fractures. Orv. Hetil. 2017. 158. (24):944-948. bitto5://doi.erg/10.1556/650.2017.30763

49. Warkentine F. H., Horowitz R., Pierce M. C.: The use of ultrasound to detect occult or unsuspected fractures in child abuse. Pediatr. Emerg. Care, 2014. 30. (1): 43-46. hittes://doliorg/L0.1092/PE C.0000000000000064.

50. Wawrzyk M. Sokal J., Andrzejewska E., Przewratil P. The role of ultrasound imaging of callus formation in the treatment of long bone fractures in children. Pol. J. Radiol. 2015. 80. 473-478. hitps://dal,ora/10.12659/PJR.894548

51. Wellsh B. M., Kuzma J. M.: Ultrasound-guided pediatric forearm fracture reductions in a resource-limited ED. Am. I. Emerg. Med. 2016. 34. (1): 40-44. hittos:l/doi. ora/10.1016/i.ajem.2015.09.013

\section{Dr. Varga Marcell}

Országos Traumatológiai Intézet

1081 Budapest, Fiumei út 17. 

A Péterfy Kómáz-Rendel bintézet Orszógos Traumotologiai Intézet a a Pecsi Tudományegyetem, Gyem ekklinika, Sebészzeti Osztäly" es a szeged Tudományegyetem, Traumatologial Klinika es Toriszek kozleménye

\title{
Gyermekkori nagy diszlokációval járó distalis radius metaphysis törések kezelése rövid elasztikus velóúrírzegezési technikával
}

\author{
DR. VARGA MARCELL ${ }^{1}$, DR. KASSAI TAMAS'ㄹ, DR. BIRÓ ZSUZSA", \\ DR. KALÓZ ERIKA', DR. GÁTI NIKOLETI, DR. JÓZSA GERGÓ2, \\ DR. PINTÉR SÁNDOR
}

\section{ÖSSZEFOGLALÁS}

A radius distalis végének törése az egyik leggyakrabban elöforduló sérülésforma gyermekkorban. A nagy diszlokációval, teljes periosteum átszakadással és összecsúszással járó törések mütéti indikációt képeznek. A mütéti megoldást többnyire tüződrótos osteosyinthesis és kiegészitő 4-6 hetes gipszrögzítés jelenti. Az alkartöréseknél sikeresen alkalmazott ESIN technika (Elastic Stable Intramedullary Nailing) módositott módszereivel a növekedési porcot elkerülö, minimál invazív technikával olyan stabil szintézis érhetö el, amely a posztoperatív rögzítési idốt is jelentösen redukálja. Cikkünkben a rövid kettös, illetve lágyrészvédelemmel ellátott rövid monoelasztikus velöürszegezést, ezek technikáját, illetve retrospektiven feldolgozott eredményeinket ismertetjük. 2013. október és 2017. október között két centrumban összesen 84 gyermek rövid kettős elasztikus szegezését végeztük el, mig 16 gyermeknél lágyrészvédôvel ellátott monoelasztikus szegezés történt. A mütéti indikáció valamennyi gyermeknél zárt, az alkar distalis harmadára lokalizálódó, nagy diszlokációval, és mindkét corticalis átszakadásával járó metaphysis vagy dia-metaphysealis átmenetben elhelyezkedổ törés volt. A physisek valamennyi esetben nyitva voltak, a gyermekek életkora 4-14 év között volt. Implantátum vándorlás nem alakult ki. Mély szeptikus szövődményt egy esetben sem észleltünk. Három esetben felületes infekció alakult ki a kettős szegezéssel ellátott csoportban, a szegek eltávolítását követően a panaszok megszüntek, a törés az eltávolitás idején már konszolidált. A kettôs elasztikus szeggel ellátott csoportban öszszesen további 9 gyermeknél észleltünk az implantátumvég által okozott bőrirritációt. A fémek eltávolítása után ezek a panaszok maradéktalanul megszüntek. A lágyrészvédelemmel ellátott csoportban implantátum okozta irritációt nem észleltünk. Ín-, illetve idegsérülést egyik csoportban sem találtunk. Az utánkövetési idö 9 hónap - 4 év volt, valamennyi gyermek teljes, oldalazonos funkcióval gyógyult. A féléves kontroll során készült röntgenfelvételen, a remodellációs szak lezajlását követően, egy kivétellel a radiuson, valamennyi esetben anatómiai tengelyállást észleltük. A rövid szegezési technika jó alternativája lehet a tüződrótos osteosynthesisnek. Elönye a physisek elkerülése, a mozgásstabil szintézis, a csökkent idejü és egyszerüsitett külsố rögzités, és a gyermekek gyors rehabilitációja. A sikeres mutéti technika az ESIN technikában, illetve gyermektraumatológiában való jártasságot igényel.

\section{Kulcsszavak: $\quad$ Gyermekkor; Intramedullaris töréskezelés; Radius törés; Szegezés;}

M. Varga, T. Kassai, Zs. Bíró, E. Kalóz, N. Gáti, G. Józsa, S. Pintér: Treatment of completely displaced distal metaphyseal fractures of the radius in children with short elastic nailing

Fractures of the distal radius are the most common injuries in children. Completely displaced and shortened fractures with periosteal rupture are candidates for osteosynthesis. The most common operative treatment is percutaneous pinning with rigid long cast immobilization for 4-6 weeks postoperatively. Using a modified ESIN method (Elastic Stable Intramedullary Nailing) a very stable, physis sparing, minimally invasive osteosynthesis can be achieved, without the need of long cast immobilization. In our paper we present the operative technique of short double elastic and soft tissue protected monoelastic nailing, and retrospectively analyze the results of our 
interventions. We reviewed retrospectively patients who underwent short double elastic or softtissue-protected nailing due to distal radial metaphyseal fractures between October 2013 and October 2017 in two Pediatric Trauma Centres. Indications for surgery included closed, severely displaced unstable metaphyseal or meta-diaphyseal radial fractures of the radius. We treated 84 children with double elastic and 16 children with mono-elastic short nails. Age of the patients was between 4 and 14 years, and all of them had open growth plates. The average follow-up time was 18.8 months (9-48 months). We have not seen any migration of the implants. There was no deep infection either. At three children a superficial skin infection has been observed, which was eliminated by removing the nails. 9 children complained to a mild skin irritation which also resolved by implant removal. Patients with soft tissue protected mono-elastic nail have not had this complain. There was no tendon or nerve injury. All of the patients regained full range of motion without further complications. Radiological remodellation was perfect in all except one case after six months. Short elastic nailing may be a good alternative technique of percutaneous pinning. Its advantage is the physis sparing method, which is stable, and reduces the time of rehabilitation. Further prospective and biomechanical investigations are necessary to verify our experience.

Keywords: $\quad$ Bone nails; Child; Fracture fixation, intramedullary-Methods; Radius fractures - Surgery;

\section{BEVEZETÉS}

A radius distalis végének törése az egyik leggyakrabban elóforduló sérülésforma gyermekkorban (11). Konzervatív kezeléssel az esetek 80-90 százalékában (torus törések, epiphyseolysisek, periosteum folytonosságát megtartó, diszlokáció nélküli és angulációval járó metaphysis törések) kiváló eredmények érhetőek el (2).

A nagy diszlokációval, teljes periosteum átszakadással és összecsúszással járó törések ugyanakkor még gyermekkorban is mütéti indikációt képezhetnek $(2,16)$. Mútéti ellátás indokolt, ha a törés primeren reponálhatatlan, illetve korai rediszlokáció alakul ki, amely a várható remodellációs kapacitást meghaladja $(2,16,19)$.

Gyermekkorban a distalis radius törések mútéti stabilizálásának legáltalánosabban elfogadott módszere a fedett, tűződrótos osteosynthesis és kiegészítő gipszrögzités (8, 17, 19). A felnőttkorban használatos lemezes szintézis a physisek hiperstimulálása, a következményes növekedési zavar lehetôsége és nyilt mütét miatt 14 éves kor alatt nem ajánlott.

A tűződrótos osteosynthesisnek ugyanakkor számos hátránya is ismert. A drótok elvándorolhatnak, a bevezetés helyén sokszor bőrirritáció illetve felületes infekció alakulhat $\mathrm{ki}$, a törésben rediszlokáció léphet fel, illetve a szintézis csak mozgás stabil, igy $4-6$ hetes, a könyökízületet is immobilizáló gipszrögzítést is igényel gyakori kontrollvizsgálatokkal $(7,20$, 21).

Külön problémát jelentenek a diametaphysis határon elhelyezkedő törések, amelyeknél a túzódrótok nem pozícionálhatóak úgy, hogy a proximalis darabot is megfelelöen rögzítsék. Ezeknél a töréseknél egyes szerzők a növekedési porcon átvezetett szintézist ajánlják, bár ismeretes, hogy ezzel a későbbi növekedési zavarok kockázatát növelik $(14,15)$.

$A z$ Országos Traumatológiai Intézet Gyermektraumatológiai Osztályán az elmúlt években több olyan eljárás is bevezetésre került, melyekkel a fenti problémák kiküszöbölhetőek. Az alkartöréseknél sikeresen alkalmazott ESIN technika módositott módszereivel a növekedési porcot elkerülö, minimál invazív technikával, olyan stabil szintézis érhető el, amely a posztoperativ rögzítési idôt is jelentősen redukálja. Cikkünkben kizárólag a rövid kettős, illetve lágyrészvédelemmel ellátott monoelasztikus velőúrszegezést, ezek technikáját illetve retrospektiven feldolgozott eredményeinket ismertetjük. 


\section{MÜTÉTI TECHNIKA}

\section{Kettős rövid elasztikus szegezés}

A mútét általános narkózisban történik. A gyermek a hátán fekszik, karja nyújtott helyzetben karasztalon. A mútét egyes lépései képerősitő kontroll mellett történnek, amelyet célszerủ a beteg láb felôli oldaláról vezetni, míg az operatör a fej felöli oldalon ül. Vértelenítö mandzsetta alkalmazása a mútéthez nem feltétlen követelmény, de ajánlott, amennyiben a szegek bevezetési pontjait - az in védelme céljából - kis feltárásból kívánjuk végezni. Lemosást és izolálást követően először a radius distalis végének repozícióját végezzük el. Amennyiben ez fedett manuális manóverekkel nem kivitelezhető, célszerű egy, a törési résbe dorsalis irányból bevezetett vastag tüződróttal $(2.5-3 \mathrm{~mm})$ segíteni a helyretételt. A drót tompa végét a törési résbe vezetve, emeló mechanizmussal, a distalis darab még jelentős összecsúszás esetén is ráemelhetö a radius proximalis végére (1. ábra).

A repozíciót követőn kiválasztjuk a szegeket. Relativ vastag, 2.5-3-as szegeket célszerü választani, amelyeket egy körülbelül 10-12 cm hosszúságú szakaszon "C" alakúvá hajlítunk. A szeg első bevezetési pontja, dorsalisan, a Lister tuberculum radialis oldala. A velőurr megnyitását a physistől proximalisan, azt nem érintve, de ahhoz a legközelebb kell megcélozni, hogy a kis distalis darabban a szeg jó tartást biztosítson a későbbiekben. Ezt követően bevezetjük az elöre meghajlitott szeget úgy, hogy a legnagyobb görbülete palmaris irányba tekint. A szeget óvatosan, görbülete mentén vezetjük elöre, amíg a vége bele nem akad a proximalis törtdarab velôüregébe. Ekkor a szeg megfeszül, és további kontrollált erőbehatással, még néhány $\mathrm{cm}$-es szakaszon továbbvezethető a velöüregben. Optimális esetben a szeg legnagyobb görbülete a törési rés magasságában van. Fontos, hogy a szeget sem ütni, sem feszegetni nem szabad, mert ezzel további iatrogén törést okozhatunk. Ha a görbület túl nagy, és a szeg nem vezethetô át a proximalis törtdarabba, vagy $1-2 \mathrm{~cm}$ után elakad és a nagy feszülés miatt nem vezethetô tovább, célszerú visszahúzni, és korrigálni az ivén, vagy vékonyabb szeget választani.
Az első szeg bevezetését követően kerülhet sor a radialis irányból való második szeg behelyezésére. A bevezetési pont itt a radius distalis és radialis oldala a physistől proximalisan, a konvencionális ESIN technikánál megszokott módon. A második szeg a rotációt stabilizálja, így lehet vékonyabb az előzőnél, kevésbé kifejezett elörehajlítással. A radialis corticalis megnyitása után ezt a szeget is görditve helyezzük be, a szeg konvexitása a radius ulnaris oldala felé néz. A törési résen való sikeres átjutás után ezt a szeget is néhány $\mathrm{cm}$ mélységben vezetjük még tovább, amig a feszülés engedi. A két szeg proximalis vége általában $1-2 \mathrm{~cm}$ szintkülönbségben helyezkedik el. Amennyiben a tengelyállás nem megfelelő, a szegek óvatos pozícionálásával ilyenkor még korrigálni tudjuk. A repozíció során a kis ad latus diszlokációk nem jelentenek problémát, alapvetően a radius distalis végének remodellációs kapacitását nem meghaladó tengelyállásra kell törekedni. A gyermek korától függőn 10-15 fokos dorsovolaris, illetve $5 \mathrm{~mm}$-es ad latus tengelyeltérés is elfogadható, egyes esetekben a régió jó remodellációs potenciálja miatt, de alapvetően anatómiai repozícióra célszerủ törekedni.

A radius stabilizálása után, az ulna törésének jelenléte esetén annak a velőürszegezését is javasoljuk elvégezni a kellő stabilitás megteremtéséhez. Az ulna velőürszegezése proximalis irányból történik és semmiben sem tér el a klasszikus ESIN technikánál alkalmazott elvektôl.

Szeglevágás: A szegek végét hajlított kéztartás mellett, a bör szintje alatt vágjuk le. $\mathrm{A}$ szegek szabad distalis végének pozícionálása különösen kritikus, mivel a túl hosszúra hagyott implantátumok bőrirritációt, mig a túl rövid, a corticalis szintjét éppen csak meghaladó fémvégek kivételi nehézséget, insérülést okozhatnak.

A mútétet követőn a végtagot néhány napig palmaris gipszsínben, majd rövid tépőzáras brace-ben rögzítjük. A külső rögzítés általában 1-2 hét, de legkésőbb 4 hét után teljesen elhagyható.

Fémkivétel a teljes radiológiai konszolidációt követôen javasolt narkózisban vagy helyi érzéstelenítésben, leghamarabb 6-8 hét után, általában 3-4 hónapos korban (2-3. ábrák). 


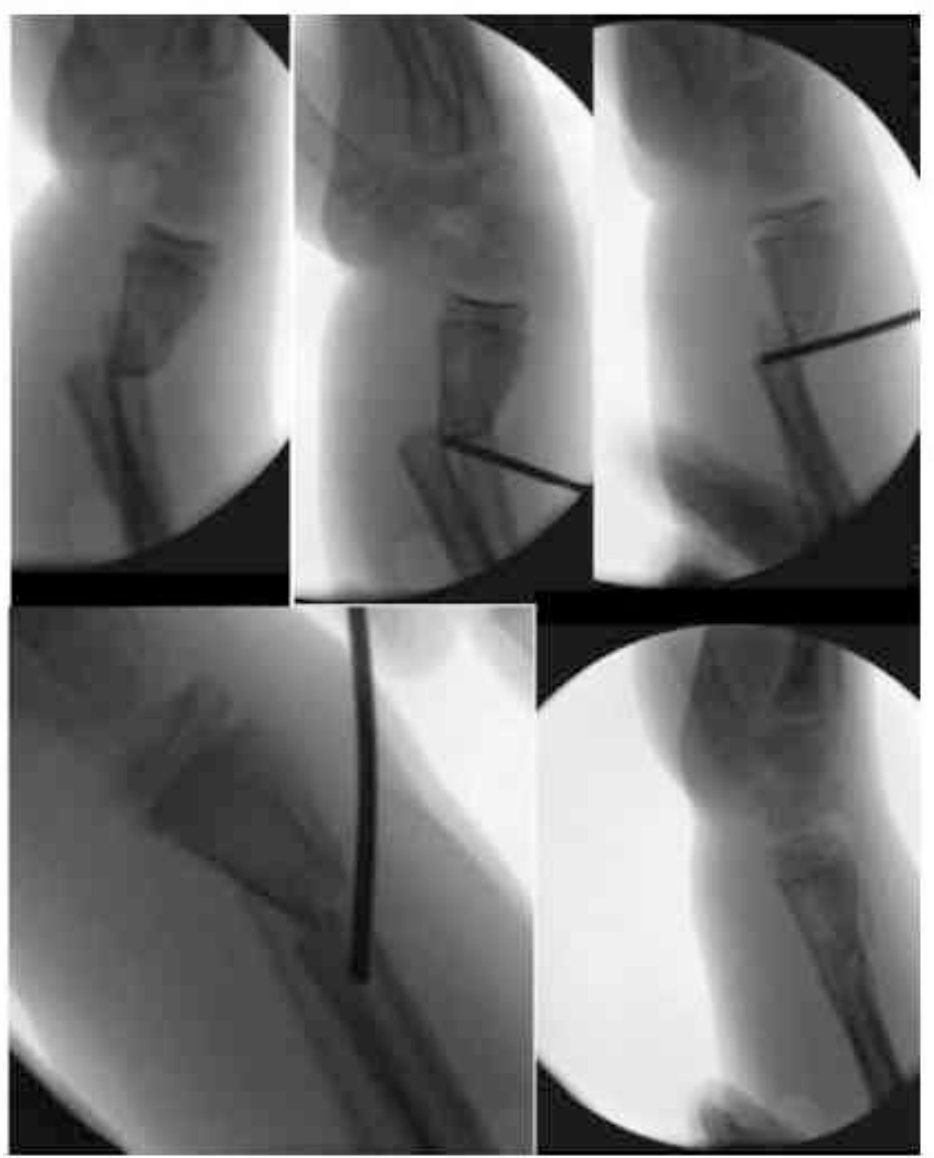

1. ábra

Repozició tompa végü tüzódróttal. A törési résbe dorsalis irányból vezetett tompa végü eszközzel a distalis darab ráemelhetố a proximalis törtdarabra

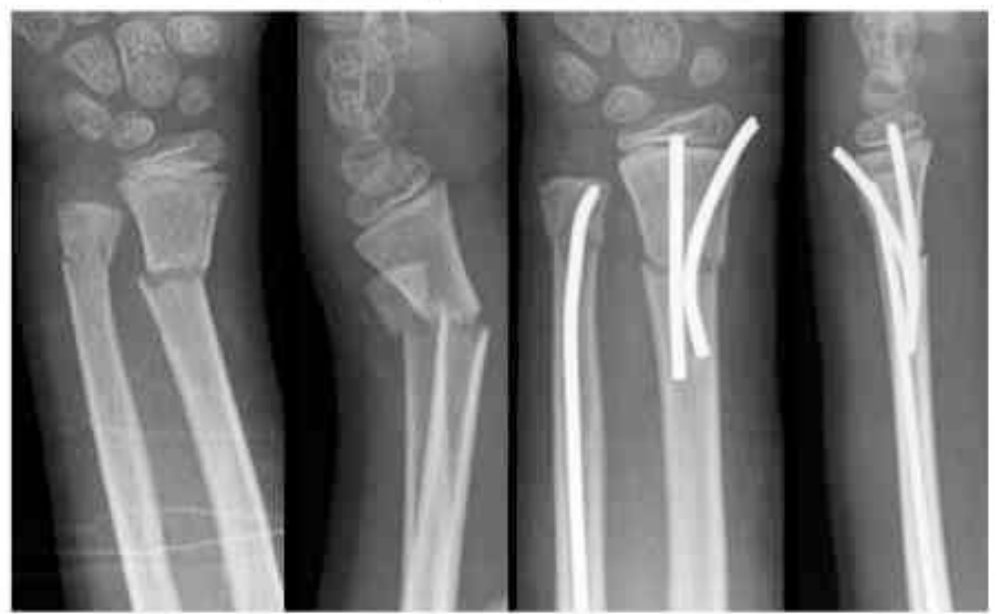

2. ábra

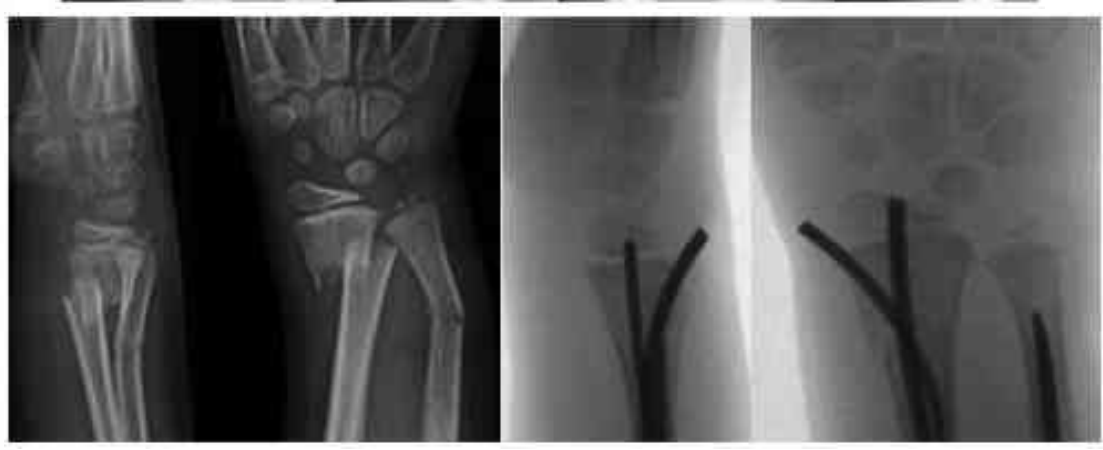

3. ábra

2-3. ábra

Dia-metaphysealis hátáron elhelyezkedố, illetve distalis metaphysis régióban kialakult radius törések kezelése kettös szegezéssel. Az ulna egyidejü törése miatt mindkét esetben annak szegezése is megtörtént, a szintézis igy mozgásstabillà válik 


\section{Módositott, lágyrészvédóvel ellátott rövid szegezés egy implantátummal}

A mütéti technika kezdeti lépései megegyeznek a kettős szegezésnél leírtakkal. Fontos különbség, hogy a mútét itt mindig vértelenítô mandzsetta használata mellett történik, hogy a lágyrész védő behelyezése során az inakat ne sértsük.

A repozíciót követóen a physistól proximalisan, dorsalisan a középvonalban másfél $\mathrm{cm}$-es haránt metszést ejtünk. Az extensor inakat látótérbe hozzuk, a velóür megnyitása az inak között, a radius középvonalában történik. A distalis darabba a korábbiakban leírt módon vezetjük be az elörehajlított szeget, úgy hogy a konvexitás palmaris irányba tekint. A repozíciót és a szeg pozícionálását követően a szeg végét úgy vágjuk le, hogy nagyjából $1 \mathrm{~cm}$-es szakasz maradjon szabadon. $\mathrm{Az}$ inak széthúzása és egyértelmű láthatóvá tétele után lágyrészvédő, menetes végú Endcapot ${ }^{\oplus}$ csavarunk a szeg végére. Az Endcap ${ }^{\circledR}$ nem haladhat át a physisen, és nem is érintheti azt.

Egyidejư ulnatörés esetén itt is elvégezzük az ulna konvencionális, proximalis irányból vezetett anterográd velöürszegezését.

A mütét végén a bört az Endcap ${ }^{\star}$ felett zárjuk. Ha az Endcap a bốrt nagyon elöboltosítja, vagy feszülést okoz, akkor azt célszerú inkább eltávolitani és a szeget rövidebbre vágni, vagy mélyebbre helyezése után ismét rácsavarni (4-5. ábrák). Az utókezelés hasonló a fentiekben leirtakhoz.
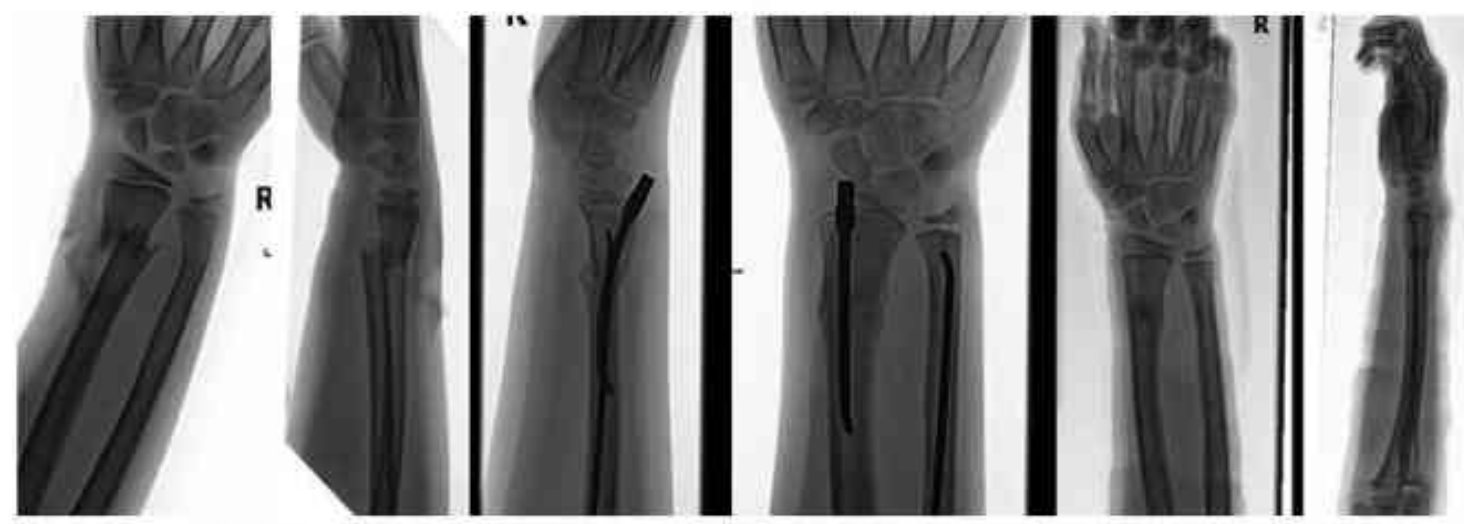

4. ábra

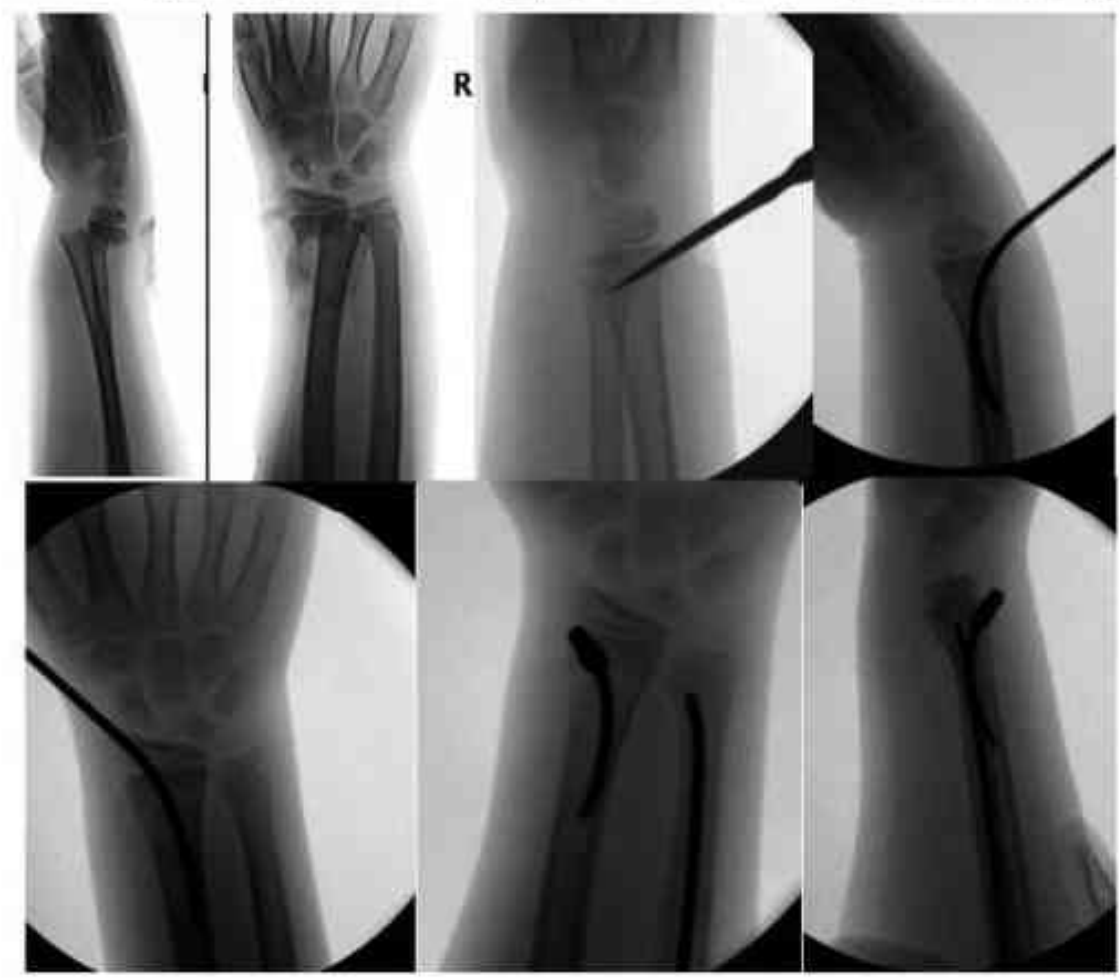

5. ábra

\section{4-5. ábra}

Lágyrészvédôvel (Endcap *) ellátott szegezés. A lágyrészvédő a physist nem érinti. A szeg bevezetési pontjának gondos meghatározásával még az egészen kis metaphysis darabbal rendelkező törések is stabilizálhatóak 


\section{ANYAG ÉS MÓDSZER}

2013. október és 2017. október között, két centrumban, összesen 84 gyermek rövid kettős elasztikus szegezését végeztük el, mig 16 esetben lágyrészvédővel ellátott monoelasztikus szegezés történt. Valamennyi mútét Synthes TEN $^{\star}$, illetve Endcap ${ }^{\star}$ implantátumokkal történt. A mútéti indikáció valamennyi gyermeknél zárt, az alkar distalis harmadára lokalizálódó, nagy diszlokációval, és mindkét corticalis átszakadásával járó metaphysis vagy dia-metaphysealis átmenetben elhelyezkedó törés volt. A physisek valamennyi esetben nyitva voltak, a gyermekek életkora 4-14 év között volt. A törések közül valamennyi zárt volt. A mütéteket összesen hat, gyermektraumatológiai ellátásban tapasztalt gyermeksebész, vagy traumatológus szakorvos, illetve szakorvosi asszisztencia mellett szakorvos jelölt végezte.

\section{EREDMÉNYEK}

Sem a kettős szegezéssel, sem a lágyrészvédelemmel ellátott mono-elasztikus szeggel ellátott csoportban nem került sor reoperációra. Implantátum vándorlás nem alakult ki. Mély szeptikus 5zövődményt egy esetben sem észleltünk.

Három esetben felületes infekció alakult ki a kettős, egy esetben a monoelasztikus szeggel ellátott csoportban, a szegek eltávolítását követően a panaszok megszüntek, a törés az eltávolítás idején már konszolidált.

A kettős elasztikus szeggel ellátott csoportban, összesen további 9 gyermeknél észleltünk az implantátum vég által okozott bórirritációt. A fémek eltávolítása után ezek a panaszok maradéktalanul megszüntek. A lágyrészvédelemmel ellátott csoportban implantátum okozta irritációt nem észleltünk. In-, illetve idegsérülést egyik csoportban sem találtunk. Az implantátumokat a 6-24. hét között - egy kivételével - minden gyermekből eltávolitottuk. Egy esetben a túl mélyre került implantátumot nem tudtuk kivenni.

$\mathrm{Az}$ utánkövetési idő 9 hónaptól 4 évig terjedt, valamennyi gyermek teljes, oldalazonos funkcióval gyógyult. Mozgásbeszúkülés, kései növekedési zavar egy gyermeknél sem alakult ki (6. ábra, I. táblázat).

A mütét után közvetlenül, a negyedik héten, illetve fél éves korban, fémeltávolítás után készült röntgenfelvételeket elemezve az alábbi eredményekre jutottunk:

A posztoperativ szakban (0-1. hét) végzett röntgenképeket anatómiainak tekintettük, ha mind AP, mind oldalirányból a maximális tengelyeltérés 5 fok alatti, jónak, ha 15 fok alatti volt, elfogadhatónak 30 fokig, ha az életkort is figyelembe véve a remodellációs határ alatti volt, illetve rossznak, ha a tengelyeltérés értéke nagyobb volt, mint a várható remodellációs potenciál.

A kettős szegezéssel ellátott csoportban 70 gyermeknél anatómiai, 13 gyermeknél jó, 1 gyermeknél elfogadható helyzetet állapítottunk meg. Az Endcap ${ }^{\circledR}$-val ellátott csoportban, 13 esetben anatómiai, 3 esetben jó eredményt találtunk. A kettôs szegezéssel ellátott csoportban, a négyhetes korban végzett kontrollröntgen némileg rosszabb radiológiai eredményt mutatott: 4 gyermek besorolása az anatómiai helyzetről jóra, 3 gyermek helyzete a jó besorolásról elfogadhatóra változott, mig egy gyermeknél rossz kategóriát állapitottunk meg. A féléves kontroll során készült felvételen ugyanakkor, a remodellációs szak lezajlását követően, egy kivétellel, valamennyi esetben anatómiai tengelyállást észleltünk. Ez utóbbi betegnél is, az egyéves radiológiai kontrollvizsgálat már jó helyzetet mutatott.

A lágyrészvédôvel ellátott csoportban nem észleltünk változást a néhány hetes posztoperativ és féléves radiológiai felvételek elemzése során (II. táblázat). 


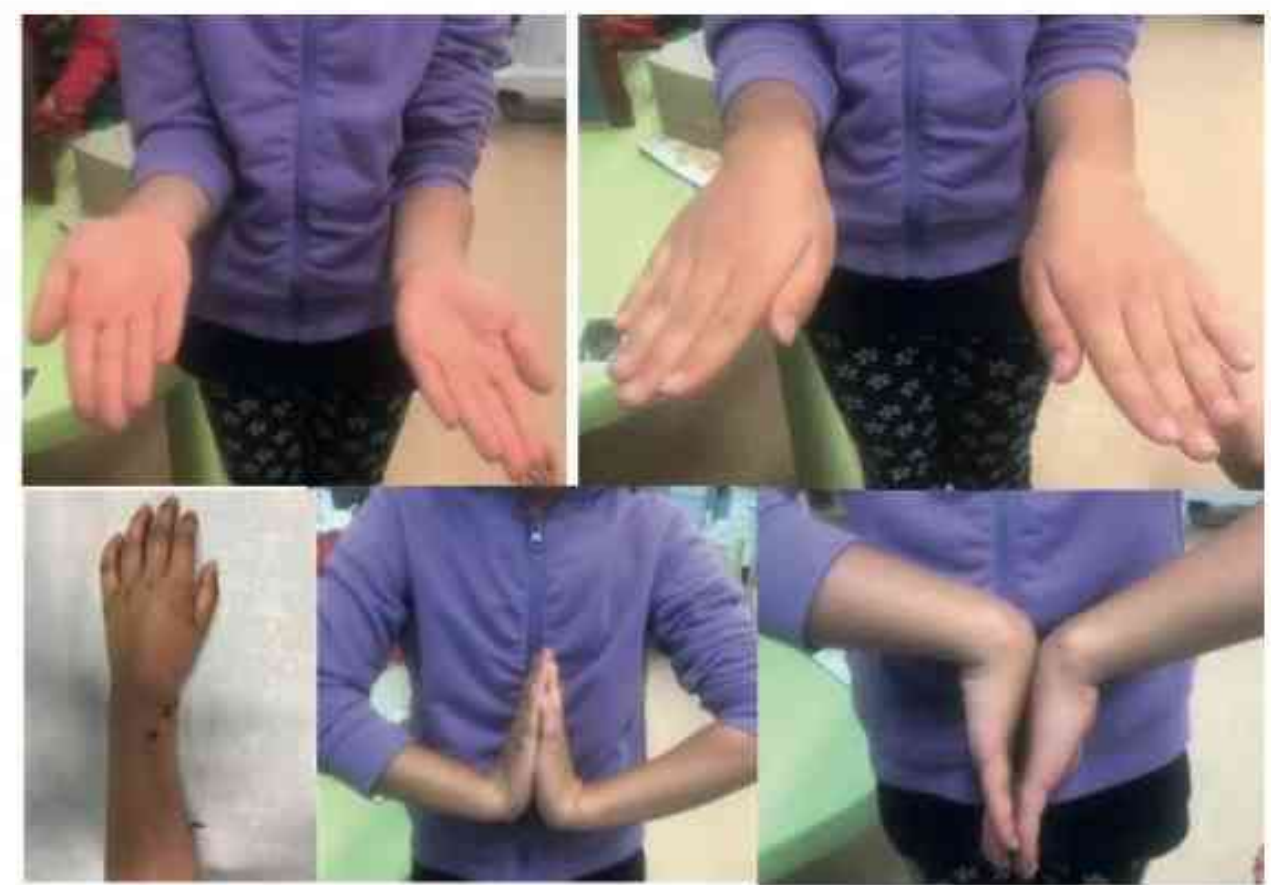

6. ábra

Friss mütéti hegek, illetve 1 éves posztoperativ funkció

\begin{tabular}{|c|c|c|c|}
\hline Kettös elasztikus szegezés & $n=84$ & $\begin{array}{l}\text { Monoelasztikus szegezés } \\
\text { Endcap rögzitéssel }\end{array}$ & $n=16$ \\
\hline Börirritáció & 9 & Bốrirritáció & 0 \\
\hline Rediszlokáció & 1 & Rediszlokáció & 0 \\
\hline Felületes infekció & 3 & Felületes infekció & 1 \\
\hline Mélyinfekció & 0 & Mélyinfekció & 0 \\
\hline Ín-vagy idegsérülés & 0 & In-vagy idegsérülés & 0 \\
\hline
\end{tabular}

\begin{tabular}{|c|c|c|c|c|c|c|c|}
\hline $\begin{array}{l}\text { Kettős elasztikus } \\
\text { szegezés } N=84\end{array}$ & $\begin{array}{c}1 . \\
\text { hét }\end{array}$ & $\begin{array}{l}4 . \\
\text { hét }\end{array}$ & $\begin{array}{l}24 . \\
\text { hét }\end{array}$ & $\begin{array}{l}\text { Mono-elaszikus szegezés } \\
\text { Endcap rögzítéssel } \mathrm{N}=16\end{array}$ & $\begin{array}{l}1 . \\
\text { hét }\end{array}$ & $\begin{array}{l}4 . \\
\text { hét }\end{array}$ & $\begin{array}{l}24 . \\
\text { hét }\end{array}$ \\
\hline $\begin{array}{l}\text { Kiváló (max. } 5 \text { fok } \\
\text { tengelyeltérés) }\end{array}$ & 70 & 66 & 83 & $\begin{array}{c}\text { Kiváló } \\
\text { (max. } 5 \text { fok tengelyeltérés) }\end{array}$ & 13 & 13 & 16 \\
\hline $\begin{array}{l}\text { Jó (max. } 15 \text { fok } \\
\text { tengelyeltérés) }\end{array}$ & 13 & 17 & 1 & $\begin{array}{c}\text { Jó } \\
\text { (max. } 15 \text { fok tengelyeltérés) }\end{array}$ & 3 & 3 & 0 \\
\hline $\begin{array}{c}\text { Megfelelố } \\
\text { (max. } 30 \text { fok tengelyel- } \\
\text { térés a remodellációs } \\
\text { határon belül) }\end{array}$ & 1 & 0 & 0 & $\begin{array}{c}\text { Megfeleleló } \\
\text { (max. } 30 \text { fok tengelyeltérés } \\
\text { a remodellációs határon } \\
\text { belül) }\end{array}$ & 0 & 0 & 0 \\
\hline $\begin{array}{c}\text { Rossz } \\
\text { (esetleges } \\
\text { remodellációs határon } \\
\text { túli eltérés) }\end{array}$ & 0 & 1 & 0 & $\begin{array}{l}\text { Rossz } \\
\text { (esetleges remodellációs } \\
\text { határon túli eltérés) }\end{array}$ & 0 & 0 & 0 \\
\hline
\end{tabular}




\section{MEGBESZÉLÉS}

A diszlokációval járó gyermekkori distalis radius törések kezeléséről nem találhatóak magas szintû evidenciák az irodalomban (2). Konzervativ kezeléssel többnyire az elmozdulás nélküli, illetve a legalább egyik periosteum intaktságát megtartott törések kezelhetőek problémamentesen $(2,16,22)$. A mútéti eljárást - az elmúlt negyven évben - a túződrótos osteosynthesis, illetve ennek számos variációja jelentette $(16,22,25)$. Egyes szerzők csak sikertelen konzervatív kezelést követően (elsó hetekben észlelt remodellációs kapacitást meghaladó rediszlokáció), mások a nagyfokban instabil törések esetén már primeren javasolnak mútétet $(2,16,22)$.

Nem egyértelmú a remodellációs kapacitás határa sem. A 15 fok alatti elmozdulás a fiúknál 12 , illetve lányoknál 10 éves kor alatt biztosan elfogadható, az ennél nagyobb, 30-40 fokig terjedő angulációval járó metaphysis törések remodellációs kapacitásáról ugyanakkor megoszlanak a vélemények $(6,9,13)$. A mindkét periosteum átszakadással és megrövidüléssel járó esetekben a rediszlokációs arány még sikeres primer fedett repozíció esetén is $40-50 \%$ lehet $(2,16,22)$.

A gyermekkori distalis diszlokált radiustörések ellátására alkalmazott tűződrótos osteosynthesis nem problémamentes módszer. A szintézis további gipszrögzitést tesz szükségessé, így a gyermek az operativ és konzervatív kezelés hátrányait is elszenvedi. Áttekintve a 2009 és 2014 között az osztályunkon operált eseteinket, meglehetősen magas szövődményarányt észleltünk. Hasonló eredményeket találunk az irodalomban, ahol igen magas, akár 20-40\%-os mútéti szövődményarányokról számolnak be. Ezek nagy része minor szövődmény, bórirritáció, felületes infekció, de osteomyelitisszel szövődött mélyinfekciókról, iatrogén Galeazzi sérülésröl, illetve reosteosynthesist szükségessé tevő rediszlokációkról is találhatóak beszámolók ( 5 , $7,17,20,21$ ). A problémák nagy része ugyan további ellátás keretében kései szövődmények nélkül megoldható (ismételt, illetve prolongált gipszrögzítés, reosteosynthesis stb.), az alkalmazott terápia elhúzódása, a végtag hosszabb immobilizációja, illetve a szükséges kontrollvizsgálatok számának növekedése jelentős időbeli és anyagi terhet jelent, mind a gyermek, mind a család számára. Annak ellenére, hogy nincs egyértelmű bizonyíték arra, hogy a növekedési zónán átvezetett Kirschner-drót növekedési zavart okozna, a legtöbb szerzó javasolja azok lehetőség szerinti elkerülését tüzés során, illetve a dia-metaphysis átmenetben észlelt törések trans-physealis szintézise után, hosszú távú utánkövetést a physisek állapotának ellenőrzésére $(1,15,18)$

$\mathrm{Az}$ elmúlt években megjelent néhány tanulmány, amelyek során distalis alkartöréseket a physiseket elkerülő elasztikus velóürszegezés módosított formáival láttak el, de ezek az eljárások is kivétel nélkül igényelnek posztoperativ 4-6 hetes gipszrögzítést $(3,4,10,12)$.

Célunk egy olyan mütéti módszer kidolgozása volt, amely a növekedési zónák megkerülésével, minimál invaziv módon, mozgásstabilan biztositja az elért helyzetet. Az általunk alkalmazott technika a klasszikus ESIN módszer minimális módositásokkal. A biomechanikai elvek lényegében ugyanazok, mint a csöves csontok diaphysis töréseinél alkalmazott hosszú szegek esetében: a csontcorticalis belsố rögzitése az elöre meghajlitott szeggel úgy, hogy a törés szintje a szeg legnagyobb görbületére essen.

A radius klasszikus elasztikus velóürszegezése esetén az előre hajlított szeg legnagyobb görbülete a diaphysis magasságában helyezkedik el, így a legnagyobb feszülést a distalisan elhelyezkedő töréstől excent-

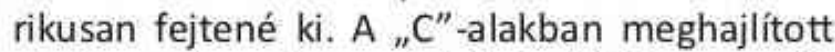
mini szegek esetén a görbület a törés magasságába kerül, így stabilizáló hatását is itt fejti ki.

$\mathrm{Az}$ axialis, illetve rotációs stabilitás eléréséhez szükséges a két, különböző pontokról inditott, relatív vastag szegek alkalmazása. Gyermekkorban a radius distalis végének a remodellációs kapacitása a növekedési porcok épsége esetén kitűnő. A szintézis során ugyan anatómiai repozícióra törekszünk, de bizonyos fokú tengelyeltérés megengedhetô. Az irodalomban általában gyermekkori radius distalis vég törések 15 fok alatti értékét a legtöbb szerző elfogadhatónak tartja. Amennyiben a mútét után ennél nagyobb tengelyeltérés nem alakul $\mathrm{ki}$, a remodelláció általában teljesen végbemegy. $A z$ eseteink egy részénél a közvetlen mútét utáni időszakban készült röntgenfelvételek mérsékelt tengelyeltéréseket igazoltak, ugyanakkor fél évvel később ezek 
mind korrigálódtak. Egy esetben észleltünk nagyobb tengelyeltérést a remodellációs határ közelében, itt reszintézist nem végeztünk, a remodellációs folyamat itt is végbement, de egy évet vett igénybe, a klinikai funkció a harmadik hónaptól ugyanakkor teljes volt.

A szegek bevezetési pontjai (Lister tuberculum és a radius distalis lateralis vége) megfelelnek a radius velőürszegezésnél használható standard behatolási zónáknak. Bár anyagunkban in, illetve idegsérülést nem tapasztaltunk, a két bevezetési ponton való áthaladás több szövődmény forrása is lehet (24).

A dorsalis bevezetés a Lister tuberculumon keresztül az extensor pollicis longus in sérülését, a radialis behatolás a nervus radialis érzóágának laesióját okozhatja. Bár irodalmi adatok és saját, alkar diaphysis törések mütétei során szerzett tapasztalataink alapján is ezeknek a szövödményeknek az esélye alacsony (1-2\% alatti), a kettös szegezési technikával elvileg növelhetjük elốfordulásukat. Az ínsérülés kiküszöbölésére több megoidás is ismert. A szeg bevezetési pontjának meghatározása történhet intraoperativ szonográfia segítségével, illetve vértelenségben végzett mütét során a Lister-tuberculum feletti kis feltárással direkt láthatóvá tétel mellett (23). A két szeg együttes alkalmazásának további hátránya lehet a bôr irritációja. Anyagunkban ez az esetek 9\%-ában fordult elö, és bár minor szövődménynek tekinthető, a gyermekek komfortérzetét jelentôsen rontja.

A fentiek miatt vezettük be a technika egy módosított formáját, amikor a rövid elasztikus szeg végére menetes lágyrészvédőt helyezünk. Az Endcap zárókupak fóleg tibia, illetve femurtörések szegezésénél használatos, az összecsúszás gátlása, a stabilitás fokozása, illetve lágyrészvédelem szempontjából. Alkartáji töréseknél való használata kevésbé terjedt el, egyes szerzók felnőttkori alkartáji törések ESIN technikával való stabilizálása során alkalmazták.

$A z$ alkar distalis végén való alkalmazásához a korábban említett kis feltárás ennél a technikánál mindenképpen szükséges az inak közelsége és a relativ nagy implantátum méret miatt. Eddigi eseteinknél úgy találtuk, hogy a menetes végú Endcap ${ }^{\circledR}$ stabilitás fokozó hatása a második szeget feleslegessé teszi és a bőr irritációját teljesen megszünteti.

A posztoperatív külső rögzítés során rövid gipszsínt, illetve tépőzáras müanyag brace-t alkalmaztunk. Ez az átmeneti külsố rögzítés inkább a kisebb gyermekek esetén volt szükséges, fóleg a komfortérzet javítása céljából, de az esetek 70 százalékában a második hét után teljesen elhagyható volt.

Vizsgálatunknak több gyenge pontja is akad. Egyelöre hiányoznak a prospektiv randomizált vizsgálatok, amelyek a fenti technikák elő́nyeit egyértelmúen igazolnák a hagyományos tűződrótos eljárással, illetve a szintén osztályunkon bevezetett módosított hosszú elasztikus velöúrszegezéssel szemben. Nincsenek biomechanikai adataink az egyszeres Endcap-pal ellátott szeg, illetve kétszeres szegezés stabilitásának erősségéről. (Jelenleg folyamatban van egy biomechanikai vizsgálat, amely az egyes szintézisek stabilitását hasonlítja össze.) A fenti technika valódi szövődmény arányairól csak a tanulási görbe időszakát is figyelembe vevő, jóval nagyobb esetszám elemzése után alkothatunk pontosabb képet.

\section{KÖVETKEZTETÉSEK}

A fenti hiányosságok ellenére úgy gondoljuk, hogy az általunk bevezetésre került rövid szegezési technika jó alternativája lehet az eddigi standard eljárásnak. Legföbb elönyének a physisek elkerülését, a mozgásstabil szintézis elérését, a csökkent idejü és egyszerûsitett kulsố rogzitést, és a gyermekek gyors rehabilitációját tartjuk. A sikeres mütéti technika az ESIN technikában, illetve gyermektraumatológiában való jártasságot igényel. További tapasztalatainkról nagyobb esetszám, megfelelő összehasonlító klinikai és biomechanikai vizsgálatokat követően fogunk beszámolni. 


\section{IRODALOM}

1. Abzug J. M., Little K., Kozin S. h.: Physeal arrest of the distal rodius. J. Am. Acad. Orthop. Surg. 2014. 22: $381-389$. httosil/doi.ora/10.5435/IAAOS-22-06-381

2. Bae D. S., Howard A. W. Distal radius fractures: what is the evidence? J. Pediatr. Orthop. 2012. 32. Suppl. 2. S128-130. https://dolorg/10.1097/BPO.0b013e31824b2545.

3. Cai H., Wang Z., Cai H.: Fixation of distal radial epiphyseal fracture: Comparison of K-wire and prebent intramedullary nail. J. Int. Med. Res. 2016, 44. (1): 122-130. httosi//doivora/10.1177/0300060514566650

4. Cai H. Wang Z., Cai H.: Prebending of a titanium elastic intramedullary nail in the treatment of distal radius fractures in children. Int. Surg. 2014. 99. (3):269-275, https://doi,org/10.9738/INTSURG-D-13-00065.1

5. Compagnone L., Ghazal R., Canavese F: minimally displaced distal radius fracture treated with closed reduction and percutaneous fixation resuiting in an fatrogenic Galeazzi lesion. J. Hand Microsurg. 2016. 8. (3): 165-169. hittps://doi.ora/10.1055/5-0036-1597089

6. Do T. T, Strub W. M., Foad S. L., Mehlman C. T., Crawford A. H. Reduction versus remodeling in pediatric distal forearm fractures: a preliminary cost analysis. I. Pediatr. Orthop. B. 2003. 12. (2): 109-115.

7. Hargreaves D. G., Drew S. L, Eckersley R.: Kirschner wire pin tract infection rates: a randomized controlled trial between percutaneous and buried wires. J. Hand Surg. Br. 2004. 29:374-376. httosi//dai. ora/10.1016/J.1HSB.2004,03.003.

8. Hellebrekers P., de Vries L. S., Timmers T. K.: Displaced distal forearm fractures in children. J. Trauma Treat. 2016. 5. (4): 1000331 bittosilldotora/10.4172/2167-1222.1000331

9. Jeroense K. T. America T., Witbreuk M. M., van der Sluijs J. A.: Malunion of distal radius fracturesin children. Acta Orthop. 2015. 86. (2): 233-237. httpsi/fdi. ord/10.3109/17453674.2014.981781

10. Joulié S. Laville J. M., Salmeron F: Posteromedial elastic stable intramedullary nailing (ESIN) in volarly displaced metaphyso-diaphyseal distal radius fractures in child. Orthop. Traumatol. Surg. Res, 2011, 97. (3): $330-334$.

11. Khosla S, Melton L. J., Dekutoski M. B., Achenbach S. J., Oberg A. L., Riggs B. Li: Incidence of childhood distal forearm fractures over 30 years: a population based study. JAMA, 2003. 290. (11): 1479-1485. https://dai.org/10.1001/iama.290.11.1479

12. Kim B. S., Lee Y. S., Park S. Y., Nho J. H., Lee S. G., Kim Y. H.: Flexible intramedullary nailing of forearm fractures at the distal metadiaphyseal junction in adolescents. Clin. Orthop. Surg. 2017. 9. (1): 101-108. httos://doi.ora/10.4055/cios.2017.9.1.101

13. Larsen E, Vittas D., Torp-Pedersen S.: Remodeling of angulated distal forearm fractures in children. Clin. Orthop. Relat. Res. 1988. 237: 190-195. hitps://doiarg/10.1097/00003086-198812000-00027

14. Lee S. C, Han S. H., Rhee S. Y: Percutaneous transphyseal pin fixation through the distal physis of the ulna in paediatric distal fractures of the forearm. J. Orthop. Trauma, 2013. 27:462-466. httos://doiorg/10.1097/Bot.0b013e3182847174

15. Lieber 1., Schmid E., Schmittenbecher P. P. Unstable diametaphyseal forearm fractures. Transepiphyseal intramedullary Kirschner-wire fixation as a treatment option in children. Eur. J. Pediatr. Surg. 2010. 6: 395-398. buttosi//doi.org/10.1055/s=0.030-1262843

16. Mclauchlan G. J., Cowan B., Annan L. H., Robb J. E.: Management of completely displaced metaphyseal fractures of the distal radius in children. A prospective, randomised controlled trial. J. Bone Joint Surg. 8r. 2002, 84. (3): $413-417$. httpsi//doi.ara/10.1302/0301-620X.84B3.11432

17. Parikh S. N., Jain V. V., Youngquist J.: Intrafocal pinning for distal radius metaphyseal fractures in children. Orthopedics, 2013. 36: 783-788. httos://doiora/10.3928/01477447-20130523-25

18. Pritchett J. W. Does pinning cause distal radial growth plate arrest? Orthopaedics, 1994. 17: 550.

19. Satish B. R., Vinodkumar M., Suresh M., Seetharam P. $Y_{4}$, Jaikumar K.: Closed reduction and $K$-wiring with the Kapandji technique for completely displaced pediatric distal radial fractures. Orthopedics, 2014. 37. (9): e810-816. hittps://doi.org/10.3928/01477447-20140825-58

7n. Subramanian P, Kantharuhna S, shilstan 5 , Pearre O 1. Complications of Kirschner-wire fixation in distal radius frartures Tech. Hand Up. Extrem. Surg. 2012. 16. (3):120-123. bitnsi//doliora/10 1097/BTH.Qbo13e31824b9abe

21. Tosti R., Foroohar A., Pizzutillo P. D., Herman M. J.: Kirschner wire infections in paediatric orthopaedic surgery. J. Pediatr. Orthop. 2015. 35. (1): 69-73. hittos:/delora/10.1097/BP0.0000000000000208

22. Van Leemput W. De Ridder K.: Distal metaphyseal radius fractures in children: reduction with or without pinning. Acta Orthop. Belg. 2009. 75. (3): 306-309.

23. Varga M., Gáti N., Kassai T., Papp S., Pintér S.: Intraoperative sonography may reduce the risk of extensor pollicis longus tendon injury during dorsal entry elastic intramedullary nailing of the radius in children. Medicine (Baltimore), 2018. 97. (24): 11167 https://dot.org/10.1097/MD.0000000000011167

24. Varga M., Józsa G., Fadgyas 8., Kassai T., Renner A.: Shart, double elastic nailing of severely displaced distal pediatric radial fractures: A new method for stable fixation. Medicine (Baltimare), 2017. 96. (14): e6532 hittosi//doi.org/10.1097/MD.0000000000006532

25. Voto S. J., Weiner D. S., Leighley B.: Use of pins and plaster in the treatment of unstable pediatric forearm fractures, J. Pediatr. Orthop. 1990. 10. (1): 85-89. hittps://dotiorg/10.1097/01241398-199001000-00016

\section{Dr. Varga Marcell}

Péterfy Kórház-Rendelőintézet Országos Traumatológiai Intézet

1081 Budapest, Fiumei út 17. 